Prepared in cooperation with the Port of Nehalem

\title{
Historical Changes in Bed Elevation and Water Depth within the Nehalem Bay, Oregon, 1891-2019
}

Scientific Investigations Report 2021-5108

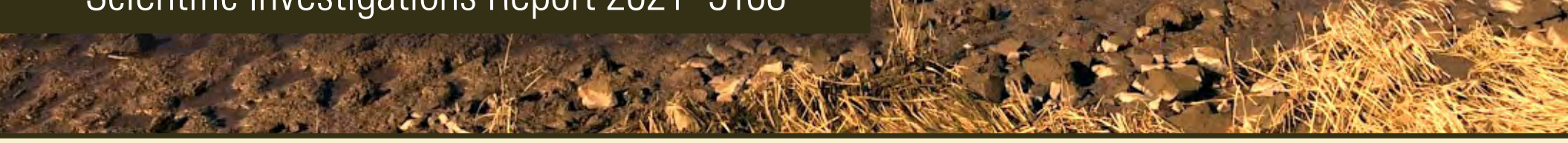

U.S. Department of the Interior

U.S. Geological Survey 
Cover: Nehalem Bay as seen from Highway 101, just west of Gallagher Slough and facing Snag Island, Oregon. Photograph by Krista Jones, U.S. Geological Survey, August 18, 2016. 


\section{Historical Changes in Bed Elevation and Water Depth within the Nehalem Bay, Oregon, 1891-2019}

By Mackenzie K. Keith, Krista L. Jones, and Gabriel W. Gordon

Prepared in cooperation with the Port of Nehalem

Scientific Investigations Report 2021-5108 


\section{U.S. Geological Survey, Reston, Virginia: 2021}

For more information on the USGS - the Federal source for science about the Earth, its natural and living resources, natural hazards, and the environment—visit https://www.usgs.gov or call 1-888-ASK-USGS.

For an overview of USGS information products, including maps, imagery, and publications, visit https://store.usgs.gov/.

Any use of trade, firm, or product names is for descriptive purposes only and does not imply endorsement by the U.S. Government.

Although this information product, for the most part, is in the public domain, it also may contain copyrighted materials as noted in the text. Permission to reproduce copyrighted items must be secured from the copyright owner.

Suggested citation:

Keith, M.K., Jones, K.L., and Gordon, G.W., 2021, Historical changes in bed elevation and water depth within the Nehalem Bay, Oregon, 1891-2019: U.S. Geological Survey Scientific Investigations Report 2021-5108, 48 p., https://doi.org/10.3133/sir20215108.

Associated data release:

Gordon, G.W., Haluska, P.A., and Overstreet, B.T., 2020, Digital elevation model of the Nehalem Bay near Wheeler, Oregon 2019: U.S. Geological Survey data release, https://doi.org/10.5066/P9VJOGM1.

ISSN 2328-0328 (online) 


\section{Acknowledgments}

Gene Dieken, Terrence Fullan, Loren Remy, Ralph Thomas, and the Port of Nehalem commissioners and staff are gratefully acknowledged for their support and contributions to the study. Patrick Haluska, Greg Lind, Brandon Overstreet, Andrew Stevens, Marc Stewart, and Rose Wallick with the U.S. Geological Survey and Tony D'Andrea with the Oregon Department of Fish and Wildlife provided their equipment and methodological advice that led to the successful collection of a new bathymetric survey in the Nehalem Bay. James White, Brandon Overstreet, Charlie Cannon, Amy Foxgrover, Heather Bervid, Laurel Stratton Garvin, Rose Wallick, and Adam Stonewall with the U.S. Geological Survey provided thoughtful insights that improved the study's analyses and presentation of findings. Jerry Hovis and Kelly Kriner from the National Oceanic and Atmospheric Administration provided insights on tidal stations within the Nehalem Bay and provided copies of historical tidal datum records. Conversations with Stefan Talke and David Jay from Portland State University informed our search of historical tidal records. Conversations with Laura Brophy from the Institute for Applied Ecology and Erin Peck and Rob Wheatcroft from Oregon State University informed our understanding of sediment deposition in the Nehalem Bay and other Oregon estuaries. 



\section{Contents}

Acknowledgments ……...................................................................................................................

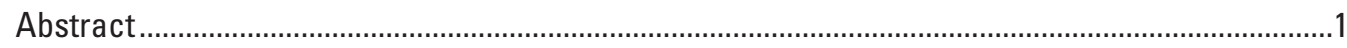

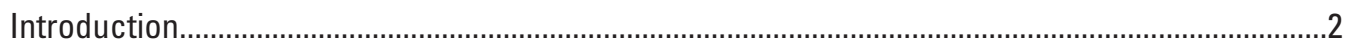

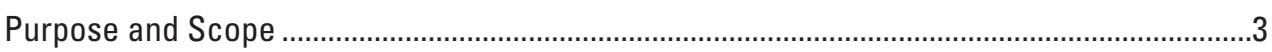

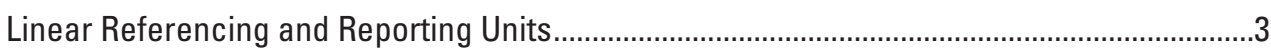

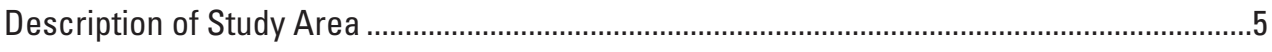

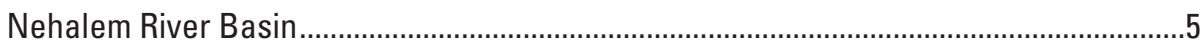

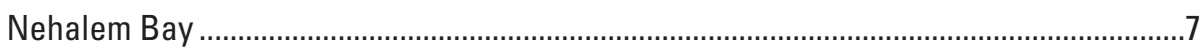

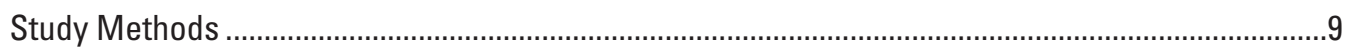

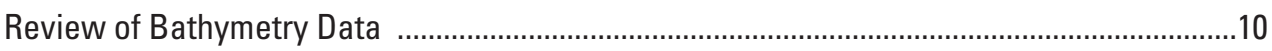

Historical Nautical Charts, 1891-2012 _.........................................................................

Hydrographic Surveys, 1868 and 1956-57 .....................................................................11

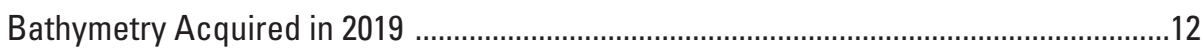

Comparison of Changes in Bed Elevations from Bathymetric Surveys, 1957 and 2019 ..........12

Conversion to a Common Vertical Datum .....................................................................13

Raster Creation and Associated Uncertainty ..............................................................13

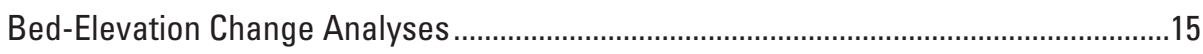

Comparison of Changes in Water Depths from Nautical Charts, 1891-2004 ..........................16

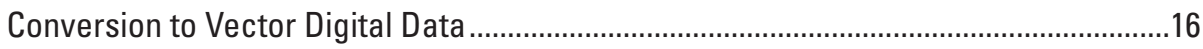

Depth Distribution Analyses ...................................................................................

Results of Bed Elevation and Bathymetric Change Analyses.......................................................17

Nehalem Bay Bed Elevations from Bathymetric Surveys, 1957 and 2019............................17

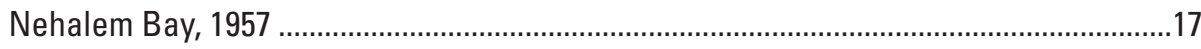

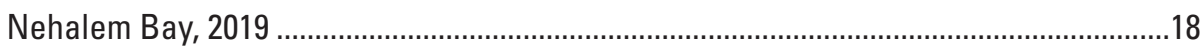

Bed-Elevation Changes from Surveys of 1957 and 2019, Rkm 10.8 to $4.4 \ldots \ldots \ldots \ldots \ldots \ldots \ldots \ldots \ldots \ldots . . . . .19$

Overall Patterns of Bed-Elevation Change ...................................................................19

Longitudinal Bed-Elevation Differences in the Thalweg................................................21

Bed-Elevation Changes at Selected Cross Sections .........................................................21

Erosion and Deposition from Digital Elevation Models of Difference..............................22

Distribution of Water Depth Values from Nautical Charts,1891-2004 .....................................24

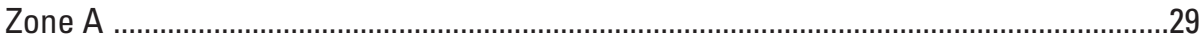

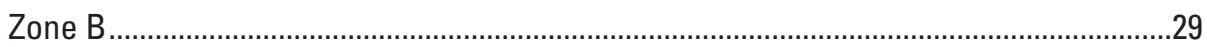

Zone C

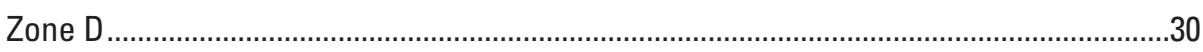

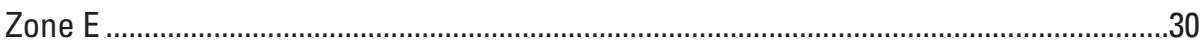

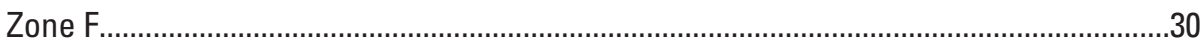

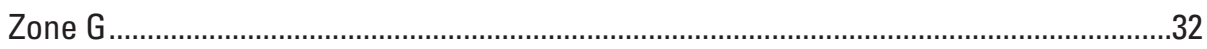

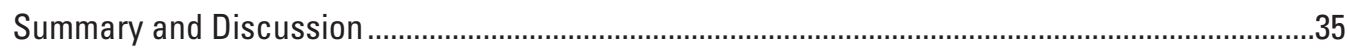

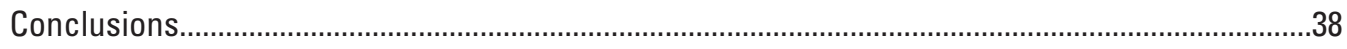

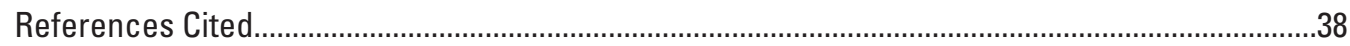

Appendix 1. Table of Water Depths by Zone from Nautical Charts ...............................................43

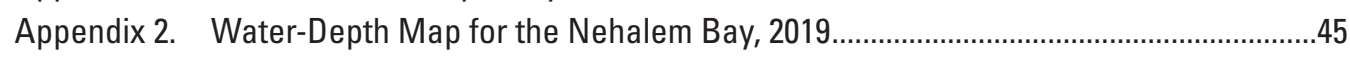

Appendix 3. Approaches for Addressing Outstanding Questions...................................................47 


\section{Figures}

1. Map showing stream network, streamflow-gaging stations, head of tide, towns, and highways in the Nehalem River Basin, northwestern Oregon

2. Map showing study area locations, linear reference systems in river kilometers and river miles, and tide stations referenced in this study of the Nehalem Bay, northwestern Oregon.

3. Maps showing channel features hannel features and wetted channel locations for the Nehalem Bay mapped by Jones and others from aerial photographs acquired in 1939 and 2009 .

4. Diagram outlining the datasets analyzed and the study's approaches for processing and evaluating changes in bed elevation from survey data collected by the U.S. Coast and Geodetic Survey in 1956-57 and the U.S. Geological Survey in 2019 and processing and evaluating changes in water depth using the nautical charts from the U.S. Coast and Geodetic Survey and National Ocean Service.

5. Map showing zones in the Nehalem Bay, northwestern Oregon, in which changes in water depth from 1891 through 2004 were evaluated.

6. Graph showing timeline of datasets, reference datums, and updates to bathymetry and nautical charts for distinct areas, or zones, of the Nehalem Bay.

7. Map showing nautical chart from 1891 for the Nehalem Bay, northwestern Oregon, at the entrance to the bay from the Pacific Ocean.

8. Map showing digital elevation models constructed from bathymetric survey data acquired in 1957 and 2019 within the Nehalem Bay, northwestern Oregon, including the outline of a polygon in which the surveys overlap.

9. Graph showing longitudinal thalweg profiles from 1957 and 2019 where surveys overlap along the river reach from river kilometer 10.8 to 4.4 of the Nehalem Bay, northwestern Oregon.

10. Graph showing survey cross sections from 1957 and 2019 along the Nehalem Bay, northwestern Oregon at selected river kilometer locations.

11. Graph showing bed-elevation changes derived from bathymetric surveys acquired in 1957 and 2019 within the Nehalem Bay, northwestern Oregon, river kilometer 10.8-4.4 for raw and probabilistic threshold change analyses.

12. Graph showing calculated volumetric change between river kilometers 10.8 and 4.4 for surveys acquired in 1957 and 2019 for the Nehalem Bay, northwestern Oregon.

13. Graph showing histograms of water depths from U.S. Coast and Geodetic Survey nautical charts for 1891, 1947, 1970, 1982, and 2004, spanning zones $A$, $B, C, D, E, F$, and $G$, within the Nehalem Bay, northwestern Oregon

14. Map showing water depths from the U.S. Coast and Geodetic Survey nautical chart publication for 1970 covering the zone A analysis area for the Nehalem Bay, northwestern Oregon.

15. Maps showing water depths from the U.S. Coast and Geodetic Survey nautical chart publications for 1947 and 1970 covering the zone B analysis area for the Nehalem Bay, northwestern Oregon....

16. Maps showing water depths from the U.S. Coast and Geodetic Survey nautical chart publications for 1891, 1947, and 1970 covering the zone $C$ and $D$ analysis areas for the Nehalem Bay, northwestern Oregon. 
17. Maps showing water depths from the U.S. Coast and Geodetic Survey nautical chart publications for 1891 and 1970 covering the zone $E$ analysis area for the

Nehalem Bay, northwestern Oregon.

18. Maps showing water depths from the U.S. Coast and Geodetic Survey nautical chart publications for 1891, 1947, 1970, 1990, and 2004 covering the zone $F$

analysis area for the Nehalem Bay, northwestern Oregon

19. Maps showing water depths from the U.S. Coast and Geodetic Survey nautical chart publications for 1891, 1947, 1970, 1990, and 2004 covering the zone G analysis area for the Nehalem Bay, northwestern Oregon

\section{Tables}

1. Summary of historical events potentially affecting streamflow, sediment supply, and hydraulic conditions in the Nehalem Bay, northwestern Oregon, since 1700 A.D .6

2. Tidal stations referenced for the Nehalem Bay, northwestern Oregon...

3. Summary of nautical charts and bathymetric data for the Nehalem Bay, northwestern Oregon, evaluated for this study

4. Summary of tide station and benchmark data used to convert depths referred to mean lower low water from the 1957 bathymetric survey of the Nehalem Bay, northwestern Oregon, to bed elevations referred to the North American Vertical 1988.

5. Digital elevation model uncertainty for 1957 and 2019 bathymetric surveys of the Nehalem Bay, northwestern Oregon

6. Bathymetric changes between 1957 and 2019 within the Nehalem Bay, northwestern Oregon, river kilometer 10.8 to river kilometer 4.4, including net, erosional, and depositional changes for the area analyzed

7. Summary of bathymetric changes for seven analysis zones within the Nehalem Bay from nautical charts spanning the years 1891-2004, including locations, area evaluated, and descriptive statistics

8. Compilation of present-day estuary area; mean annual suspended sediment loads, and relative sediment load for fifteen estuaries along the Oregon coast. 


\section{Conversion Factors}

International System of Units to U.S. customary units

\begin{tabular}{|c|c|c|}
\hline Multiply & By & To obtain \\
\hline \multicolumn{3}{|c|}{ Length } \\
\hline centimeter $(\mathrm{cm})$ & 0.3937 & inch (in.) \\
\hline millimeter $(\mathrm{mm})$ & 0.03937 & inch (in.) \\
\hline meter $(\mathrm{m})$ & 3.281 & foot $(\mathrm{ft})$ \\
\hline kilometer (km) & 0.6214 & mile (mi) \\
\hline kilometer (km) & 0.5400 & mile, nautical (nmi) \\
\hline meter $(\mathrm{m})$ & 1.094 & yard (yd) \\
\hline \multicolumn{3}{|c|}{ Area } \\
\hline square meter $\left(\mathrm{m}^{2}\right)$ & 0.0002471 & acre \\
\hline square hectometer $\left(\mathrm{hm}^{2}\right)$ & 2.471 & acre \\
\hline square kilometer $\left(\mathrm{km}^{2}\right)$ & 247.1 & acre \\
\hline square meter $\left(\mathrm{m}^{2}\right)$ & 10.76 & square foot $\left(\mathrm{ft}^{2}\right)$ \\
\hline square kilometer $\left(\mathrm{km}^{2}\right)$ & 0.3861 & square mile $\left(\mathrm{mi}^{2}\right)$ \\
\hline \multicolumn{3}{|c|}{ Volume } \\
\hline cubic meter $\left(\mathrm{m}^{3}\right)$ & 6.290 & barrel (bar) \\
\hline cubic meter $\left(\mathrm{m}^{3}\right)$ & 264.2 & gallon (gal) \\
\hline cubic meter $\left(\mathrm{m}^{3}\right)$ & 0.0002642 & million gallons (Mgal) \\
\hline cubic meter $\left(\mathrm{m}^{3}\right)$ & 35.31 & cubic foot $\left(\mathrm{ft}^{3}\right)$ \\
\hline cubic meter $\left(\mathrm{m}^{3}\right)$ & 1.308 & cubic yard $\left(\mathrm{yd}^{3}\right)$ \\
\hline cubic meter $\left(\mathrm{m}^{3}\right)$ & 0.0008107 & acre-foot (acre-ft) \\
\hline \multicolumn{3}{|c|}{ Flow rate } \\
\hline cubic meter per second $\left(\mathrm{m}^{3} / \mathrm{s}\right)$ & 70.07 & acre-foot per day (acre-ft/d) \\
\hline cubic meter per year (m³/yr) & 0.000811 & acre-foot per year (acre-ft/yr) \\
\hline cubic meter per second $\left(\mathrm{m}^{3} / \mathrm{s}\right)$ & 35.31 & cubic foot per second $\left(\mathrm{ft}^{3} / \mathrm{s}\right)$ \\
\hline cubic meter per second $\left(\mathrm{m}^{3} / \mathrm{s}\right)$ & 22.83 & million gallons per day $(\mathrm{Mgal} / \mathrm{d})$ \\
\hline millimeter per year (mm/yr) & 0.03937 & inch per year (in/yr) \\
\hline \multicolumn{3}{|c|}{ Mass } \\
\hline metric ton $(\mathrm{t})$ & 1.102 & ton, short $(2,000 \mathrm{lb})$ \\
\hline metric ton $(\mathrm{t})$ & 0.9842 & ton, long $(2,240 \mathrm{lb})$ \\
\hline
\end{tabular}

\section{Datums}

Elevation or vertical coordinate information is referenced to the North American Vertical Datum of 1988 (NAVD 88) unless otherwise noted. Water depth is referenced to local mean lower low water within the Nehalem Bay.

Horizontal coordinate information is referenced to the North American Datum of 1983 (NAD 83). 


\section{Abbreviations}

$\begin{array}{ll}\text { DEM } & \text { digital elevation model } \\ \text { MHHW } & \text { mean higher high water } \\ \text { MHW } & \text { mean high water } \\ \text { MLLW } & \text { mean lower low water } \\ \text { NAIP } & \text { National Agriculture Imagery Program } \\ \text { NOAA } & \text { National Oceanic and Atmospheric Administration } \\ \text { NOS } & \text { National Ocean Service } \\ \text { NAD27 } & \text { North American Datum of 1927 } \\ \text { NAD83 } & \text { North American Datum of 1983 } \\ \text { NAVD88 } & \text { North American Vertical Datum of } 1988 \\ \text { NGVD29 } & \text { National Geodetic Vertical Datum of 1929 } \\ \text { Rkm } & \text { river kilometer } \\ \text { RM } & \text { river mile } \\ \text { SAR } & \text { sediment accumulation rate } \\ \text { SSC } & \text { suspended sediment concentration } \\ \text { USDA } & \text { U.S. Department of Agriculture } \\ \text { USGS } & \text { U.S. Geological Survey } \\ \text { USCGS } & \text { U.S. Coast and Geodetic Survey } \\ & \end{array}$




\section{Definitions of Terms Used in Report}

\author{
Bathymetry \\ Digital Elevation \\ Model (DEM) \\ DEMs of difference \\ Head of tide \\ Horizontal datum \\ Hydrography \\ Mean lower low \\ water (MLLW) \\ National Tidal Datum \\ Epoch
}

Nautical chart

Smooth Sheets

Sonar

Soundings

Thalweg

Tidal station
Topography (or mapping of earth surface features) below water and typically described by bed elevation or water depth relative to some vertical datum.

Continuous surface representing the elevation of a terrain (commonly the earth surface) as regularly spaced grid cells (or "rasters").

Elevation change dataset resulting from the subtraction of DEMs from two periods.

Upstream extent of tidal influence along a river.

The coordinate system for latitude and longitude on the Earth.

The science of surveying and charting bodies of water, such as seas, lakes, and rivers.

The lowest of the two low tides per day (or the one low tide) averaged over a 19-year period called the National Tidal Datum Epoch (defined below; National Oceanic and Atmospheric Administration, 2020g).

Official period adopted by the National Ocean Service. Tide level observations over 19-year epochs (non-consecutive) are averaged to develop tidal datums (National Oceanic and Atmospheric Administration, 2020g), such as mean lower low water (MLLW) referenced for the Nehalem Bay, Oregon.

A map showing the shoreline and seafloor along with water depths, locations of navigation dangers, and other features.

Map of soundings made with sextant angles to shore-based navigation stations (instead of latitude and longitude coordinates) as well as shoreline, geographic, and navigational features; these maps serve as internal visual records of hydrographic surveys for the National Ocean Service and often provide more detail than navigation charts (Zimmerman and Benson, 2013).

A system for the detection of objects or the bed surface under water and for measuring water depth by emitting sound pulses and detecting or measuring their return after being reflected.

Water depth measurements.

A line following the deepest part (or lowest elevation) of the channel.

Location where water levels affected by tides are monitored or predicted in coastal areas. Tide stations types may be either harmonic or subordinate. Harmonic stations have tidal harmonic constants and tidal datums (determined from observations of water level), whereas subordinate stations provide tide predications based on reference harmonic stations (National Oceanic and Atmospheric Administration, 2020f). During historical hydrographic surveys within the Nehalem Bay, temporary portable tide stations were also used to measure water levels. Tide stations that continuously record water level are referred to as harmonic. Subordinate tide stations provide predictions of tide levels based on observed data at harmonic stations. 


\title{
Historical Changes in Bed Elevation and Water Depth within the Nehalem Bay, Oregon, 1891-2019
}

\author{
By Mackenzie K. Keith, Krista L. Jones, and Gabriel W. Gordon
}

\section{Abstract}

Estuaries, at the nexus of rivers and the ocean, are depositional areas that respond to changes in streamflow, tides, sea level, and inputs of sediment from marine and watershed sources. Understanding changes in bed elevations, deposited and eroded sediment, and water depth throughout estuaries is relevant for understanding their present-day status and long-term evolution, identifying potential hazards to human communities, and informing estuarine conservation. In response to observations of sedimentation in the Nehalem Bay, northwestern Oregon, by the Port of Nehalem, the magnitudes and patterns of bathymetric change in the Bay were documented and described by two approaches. The first approach compared changes in bed elevation with estimated volumes of erosion and deposition from overlapping survey data acquired in 1957 and 2019 for the area of the Nehalem Bay from upstream of the Highway 101 bridge to downstream of Fishery Point. The second approach examined changes in water depth for seven zones from the confluence of the North Fork and Nehalem Rivers to the mouth of the Nehalem River using nautical charts (1891, 1947, 1970, 1990, and 2004). These two approaches were used because the bathymetric surveys from 1957 and 2019 could be tied to a common vertical datum, allowing for a direct comparison of changes in bed elevations, whereas the nautical charts could not be tied to a common vertical datum, which limited the analyses to a comparison of changes in water depths over a broader time frame.

Bed elevation changes from 1957 to 2019 were assessed from upstream of the Highway 101 bridge to downstream of Fishery Point where the two surveys overlapped (2 square kilometers) using thalweg longitudinal profiles, channel cross sections, and digital elevation models (DEMs) showing the elevation differences between the two surveys (or DEMs of difference). The most prominent change between 1957 and 2019 was the migration of the thalweg (or deepest part of the channel) between the downstream end of Lazarus Island and downstream of Fishery Point; this migration resulted in sediment deposition in the former thalweg and sediment erosion in formerly shallow areas to form the new thalweg. Bed elevation changes in the thalweg also varied longitudinally between 1957 and 2019. The bed elevation of the thalweg in both surveys, however, was generally less than 1 meter (m). The thalweg in the area of overlapping surveys shortened from about 7.0 to 6.7 kilometers in length over that same period. The bed elevation changes between the DEMs showed that maximum erosion and deposition was 4.3 and $4.5 \mathrm{~m}$, respectively. In this same time period, the net change in sediment volume was 230,000 cubic meters $\left(\mathrm{m}^{3}\right)$, indicating net deposition. However, the error estimated for the 95 percent confidence interval analyses is $\pm 315,000 \mathrm{~m}^{3}$, and therefore does not preclude the possibility that net erosion may have occurred.

Historical changes in water depth from soundings depicted on nautical charts from 1891, 1947, 1970, 1990, and 2004 were evaluated by assessing spatial and temporal changes for seven zones of the Nehalem Bay. Across all years and zones, water depths ranged from about 0.2 to 9.4 $\mathrm{m}$, whereas median water depths ranged from 0.3 to $6.4 \mathrm{~m}$. Median depths and the range of water depths did not systematically increase or decrease throughout all zones during the same periods. In all nautical charts, the zone at the mouth of the Nehalem River consistently had the deepest soundings (7.9 to $9.4 \mathrm{~m}$ ) and the greatest range of water depths $(7.3$ to $8.8 \mathrm{~m})$. Qualitative evaluation of the nautical charts showed minimal changes in the overall shape of the Nehalem Bay. The exception to this observation was at the mouth of the Bay, where two historical outlets to the Pacific Ocean depicted in the 1891 nautical chart were reduced to one outlet following the construction of jetties (1916 and 1918).

The results of this study emphasize that bed elevations and water depths within the Nehalem Bay have varied between 1891 and 2019, as illustrated by the lateral and vertical changes in the thalweg and changes in water depths over time. Changes in thalweg position and related patterns of sediment erosion and deposition are expected in the future as the Nehalem Bay continues to respond to changes in tides, sea level, streamflow, and sediment inputs from watershed and marine sources. The results of this study and the surveys from 1957 and 2019 provide a foundation for documenting and evaluating future changes in the Nehalem Bay and prioritizing actions to manage and protect natural resources and recreational access to the Nehalem Bay. 


\section{Introduction}

At the nexus of rivers and the ocean, estuaries are lowgradient areas where reductions in water velocity and the influence of tides result in the deposition and accumulation of fine sediment (sands, silts, and clays; Dyer, 1995). Patterns of sediment deposition and erosion in estuaries are shaped by sediment inputs from marine and watershed sources; streamflow, tides, ocean and estuary circulation patterns; and estuary morphology (for example, Dyer, 1995; Perillo, 1995; Komar and others, 2004). Assuming static sea and base levels, sediment erosion lowers bed elevations and increases water depths, whereas sediment deposition increases bed elevations and decreases water depths over time. Sediment erosion and deposition and associated changes in water depth (or bathymetry) can affect water conveyance, river navigation, estuarine habitats (Thrush and others, 2004), and flood hazards for nearby coastal communities. Understanding historical changes in sediment erosion and deposition and water depth throughout estuaries therefore is relevant for mitigating potential hazards for human communities and informing estuarine conservation.

A common approach for documenting changes in sediment deposition and erosion and water depth in estuaries is a bathymetric assessment, which involves the comparison of multiple bathymetric datasets collected at different times to identify locations where water depths have increased or decreased and where the location of the channel thalweg (or deepest part of the channel) has migrated over time. Such comparisons are helpful for gaining insights into patterns of sediment deposition and erosion and changes in estuary morphology. For example, historical bathymetric assessments have been done for the Columbia River estuary (Sherwood and others, 1990), Tillamook Bay (Bernert and Sullivan, 1998), and Umpqua River estuary (Wallick and others, 2011) along the Oregon Coast to inform estuarine and sediment management. Examples of historical bathymetric studies outside of Oregon include those done in San Pablo Bay, California (Jaffe and others, 2007), San Francisco Bay, California (Foxgrover and others, 2004; Jaffe and Foxgrover, 2006), the MississippiAlabama coastal region (Buster and Morton, 2011), and England (van der Wal and Pye, 2003).

In recent decades, sediment deposition and reductions in water depth have been observed in the Nehalem Bay along the northern coast of Oregon (fig. 1). In particular, sediment deposition has been observed in Gallagher Slough and near Snag Island, Lazarus Island, and the town of Wheeler across the channel from Lazarus Island (River kilometer [Rkm] 9.7 to 7.4; fig. 2; Loren Remy, former Port of Nehalem board member, oral commun., May 2018). Sediment deposition near these islands, channels, and sloughs may result in potential adverse impacts to recreational river navigation, reductions in estuarine habitats for juvenile salmonids, and flood risks for infrastructure near Wheeler.

These observations of sediment deposition by the Port of Nehalem are consistent with a recent U.S. Geological Survey (USGS) study that documented increases in bar area and decreases in channel width in the Nehalem Bay from aerial photographs acquired in 1939 and 2009 (fig. 3; Jones and others, 2012). Furthermore, Peck and others (2020) collected sediment cores from seven estuaries along the Oregon coast and found that samples from low and high marshes in the Nehalem Bay had the greatest sediment accumulation rates (SAR) of $2.8 \pm 0.4$ and $2.9 \pm 1.0$ millimeters per year $(\mathrm{mm} /$ year), respectively. Low marshes are tidal marshes below mean higher high water (MHHW), whereas high marshes are located above MHHW. The SARs for the Nehalem Bay also exceeded the local estimated relative rate of sea level rise $(0.9$ $\pm 1.0 \mathrm{~mm} /$ year), indicating that sediment accumulation in the wetlands of the Nehalem Bay may increase their resistance to drowning with future sea level rise (Peck and others, 2020).

The goal of the study described here, which was conducted by the USGS in cooperation with the Port of Nehalem, was to quantify and document long-term bathymetric changes in the Nehalem Bay from 1891 to 2019 by comparing multiple bathymetric datasets (as summarized in the "Study Methods" section). The datasets differ in spatial extent, spatial resolution, level of uncertainty in bathymetry, and supporting data necessary to convert the datasets to a common vertical datum for direct comparisons. Therefore, two approaches were used to document and describe the magnitudes and patterns of depth changes within the Nehalem Bay: 1) direct comparison of bed elevation changes in the survey datasets from 1957 and 2019 and 2) analyses of the distribution of water depth values from nautical charts. These two approaches were used because: 1) the bathymetric surveys from 1957 and 2019 could be tied to a common vertical datum, allowing for a direct comparison of changes of bed elevations, and 2) the nautical charts could not be tied to a common vertical datum, which limited data analyses to a comparison of changes in water depths but over a broader time frame. Quantifying approximate changes in bed elevation and water depth over time will provide a baseline for understanding the extents and rates of historical sediment deposition and erosion and help inform sediment management decisions for the Nehalem Bay. This study did not identify potential marine or watershed sources of sediment, nor did it investigate the underlying mechanisms for changes in sediment transport, such as changes in land use or natural variability in the supply and delivery of sediment to the Nehalem Bay. 


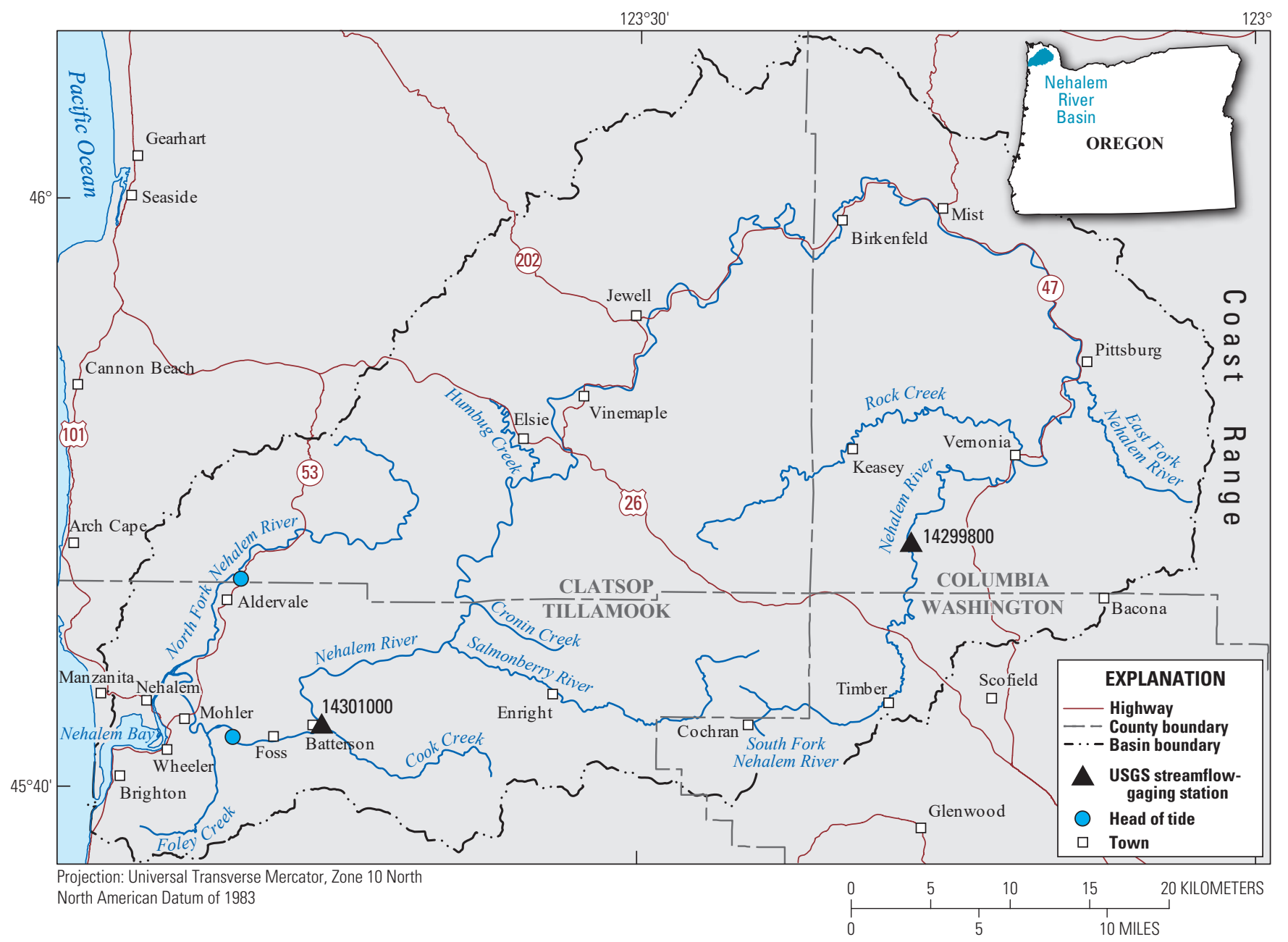

Figure 1. Stream network, streamflow-gaging stations, head of tide, towns, and highways in the Nehalem River Basin, northwestern Oregon.

\section{Purpose and Scope}

The purpose of this report is to provide the Port of Nehalem with documentation of the study approach and findings. This report describes (1) the available bathymetric datasets and nautical charts for the Nehalem Bay, (2) methods used for assessing bed elevation change and estimated volumes for eroded and deposited sediment from 1957 to 2019 and changes in water depth from 1891 to 2004, and (3) results of the change analyses. This report also documents and describes six key findings regarding the magnitudes and patterns of long-term bathymetric changes in the Nehalem Bay and provides a brief discussion of approaches for evaluating future changes and prioritizing actions to manage and protect natural resources and recreational access to the Nehalem Bay.

\section{Linear Referencing and Reporting Units}

Locations within the study area are referenced to $\mathrm{Rkm}$ (fig. 2). Jones and others (2012) developed this reference system to identify points along a wetted-channel centerline mapped from aerial imagery acquired in 2009 by the U.S. Department of Agriculture's (USDA) National Agriculture Imagery Program (NAIP). Points were distributed at 0.2-kilometer $(\mathrm{km})$ intervals along these centerlines, with the values increasing in the upstream direction. The values in the $\mathrm{Rkm}$ linear reference system differ from those in the river mile (RM) linear reference system shown on the recent U.S. Geological Survey (USGS) topographic quadrangle maps for the Nehalem River because the Rkm reference system starts at the mouth of the Nehalem River, whereas the RM reference system starts near Bott's Marsh (Rkm 9.4; fig. 2). Locations describing the sides of channels or the Nehalem Bay are referenced as right and left, determined as if looking downstream. Data in this publication are reported in International System (or metric) units, which can be converted to U.S. customary (or English) units by using the conversion factors listed in the front material of this report. 


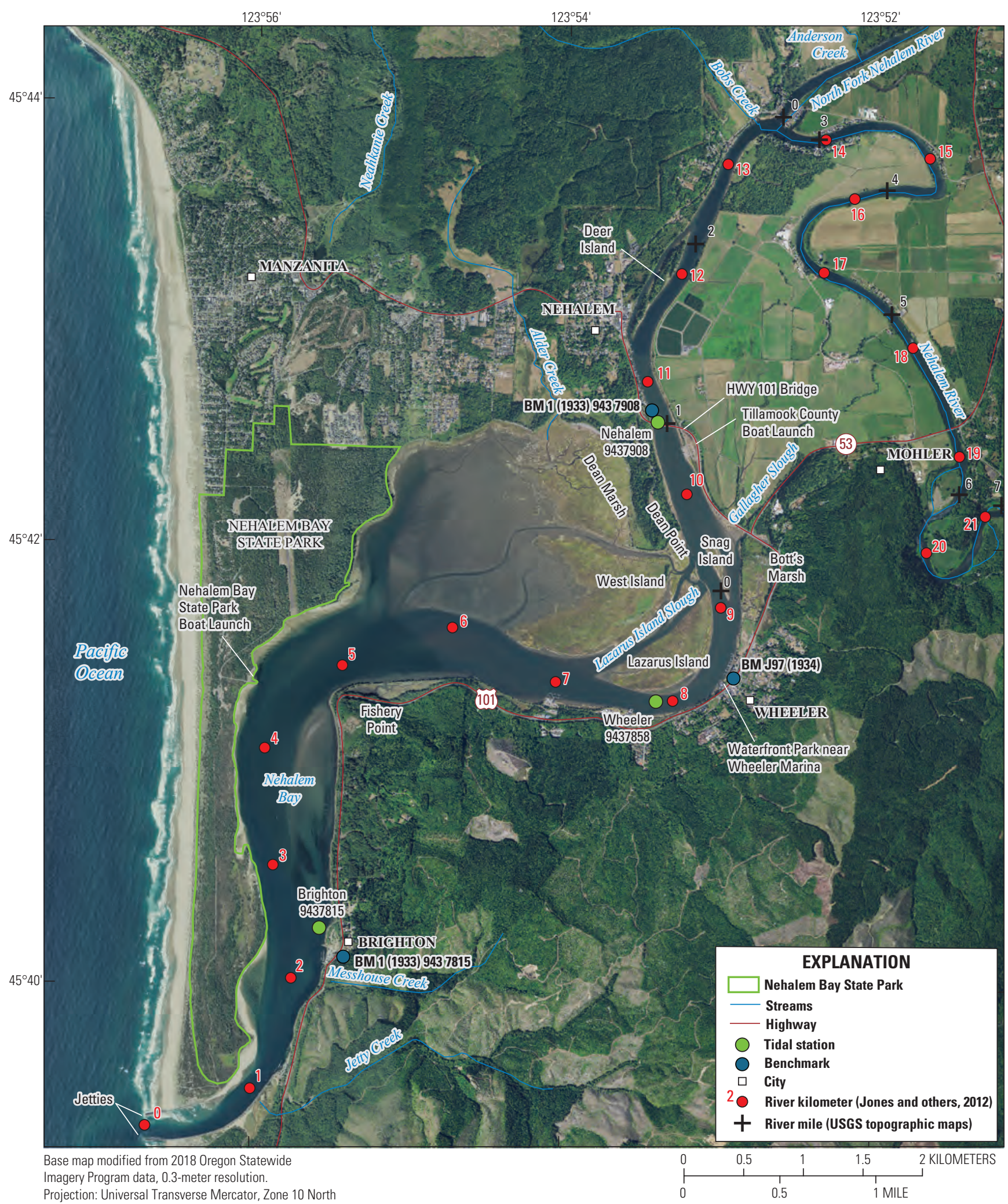

Projection: Universal Transverse Mercator, Zone 10 North

Figure 2. Study area locations, linear reference systems in river kilometers ( $\mathrm{Rkm}$ ) (from Jones and others, 2012) and river miles (RM), and tide stations referenced in this study of the Nehalem Bay, northwestern Oregon. 

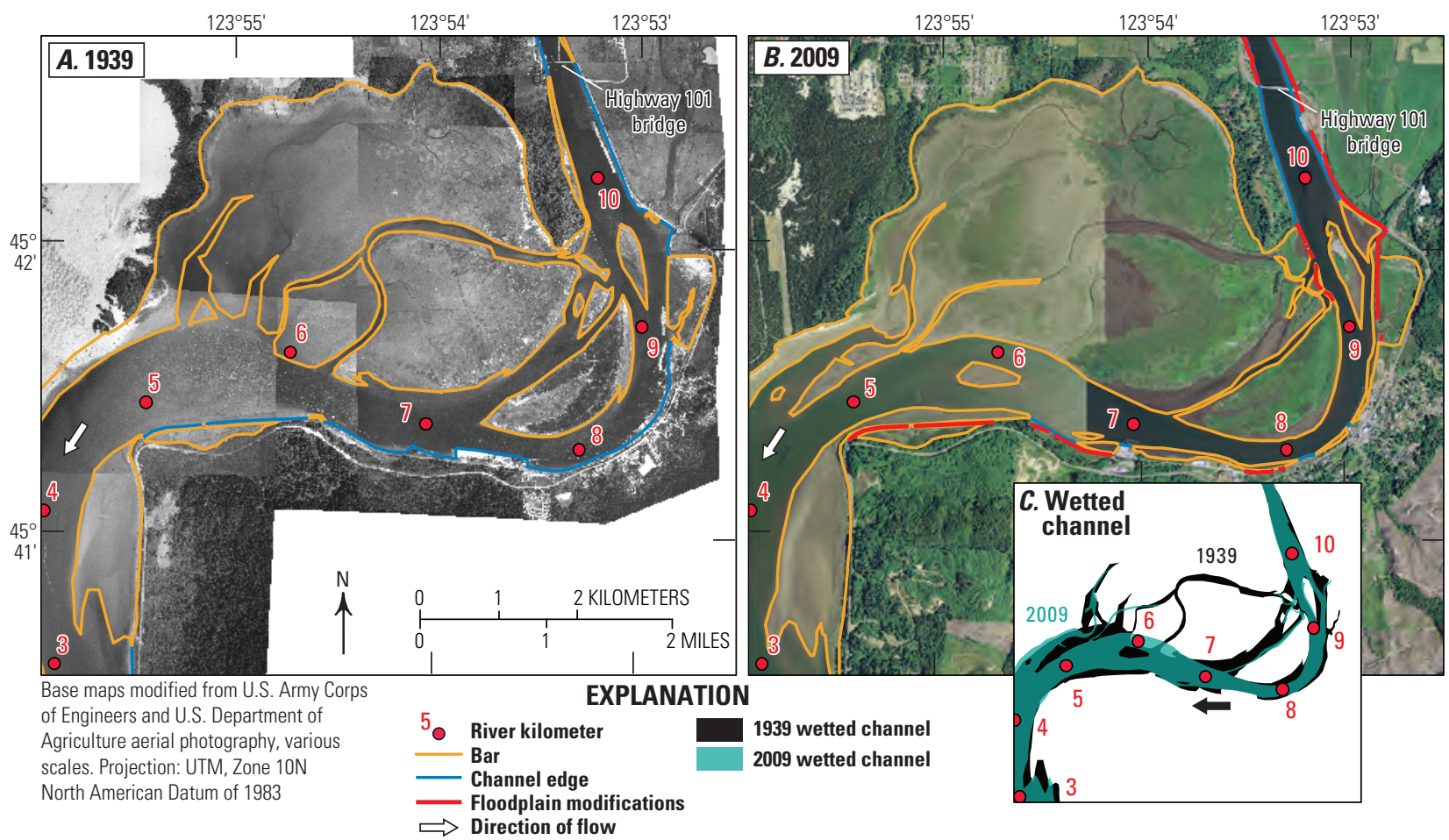

Figure 3. Maps showing channel features and wetted channel locations for the Nehalem Bay mapped by Jones and others (2012) from aerial photographs acquired in $(A) 1939$ and $(B)$ 2009. The Nehalem Bay is tidally influenced, and mapping did not account for differences in tidal stages, which were unknown at the time of photograph acquisition. Figure modified from Jones and others (2012).

\section{Description of Study Area}

\section{Nehalem River Basin}

The Nehalem River Basin, located in northwestern Oregon, drains 2,207 square kilometers $\left(\mathrm{km}^{2}\right.$; fig. 1). The Nehalem River originates in the rugged Oregon Coast Range mountains, which are affected by mass movements, including shallow landslides, debris flows, and deeper earthflows and landslides (Johnson and Maser, 1999). Stream valleys carved into the soft sedimentary rocks are locally flanked by Quaternary alluvium as well as by marine terraces and dunes near the coast. Tide affects $24.6 \mathrm{~km}$ of the lower Nehalem River beginning downstream of the town of Foss, Oregon (Rkm 27.8), as well as about the lower $10 \mathrm{~km}$ of the North Fork Nehalem River (Oregon Department of State Lands, 2017). Downstream of the confluence of the North Fork and Nehalem Rivers, the Nehalem River widens to form the Nehalem Bay, where the towns of Nehalem, Wheeler, and Brighton, marinas, and other developed areas are located.

Historical events and land-use activities that influence streamflow, sediment supply, and hydraulics in the Nehalem Bay are summarized in table 1. Land-use activities that are relevant for understanding sediment and morphology changes in the Nehalem Bay include construction of the jetties, dredging, in-stream gravel mining, splash dams and log drives, and floodplain modifications. The U.S. Corps of Engineers (USACE) constructed the south and north jetties at the mouth of the Nehalem Bay in 1916 and 1918, respectively (U.S. Army Corps of Engineers, 2020). Reported dredging in the Nehalem Bay by Federal entities is limited, and approximately $9,500 \mathrm{~m}^{3}$ of sand was removed during 1932-33 (Ferdun, 2007). The USACE, however, does not currently dredge the Nehalem River or Nehalem Bay because of the absence of a Federal navigation channel (Katharine Groth, U.S. Army Corps of Engineers, written commun., 2010). From 2003 to 2012, permitted in-stream gravel mining on the Nehalem River just upstream of the head of tide removed more than 65,000 cubic meters $\left(\mathrm{m}^{3}\right)$ of sediment (Jones and others, 2012). Historically, the waterways of the Nehalem Basin were used for driving timber to the mills near Wheeler, but present-day navigation uses are mainly recreational boating. Floodplain modifications (or levees, dikes, and naturally formed levees reinforced with non-erodible materials) border approximately 28 percent of the Nehalem River that is affected by tide (Jones and others, 2012). 


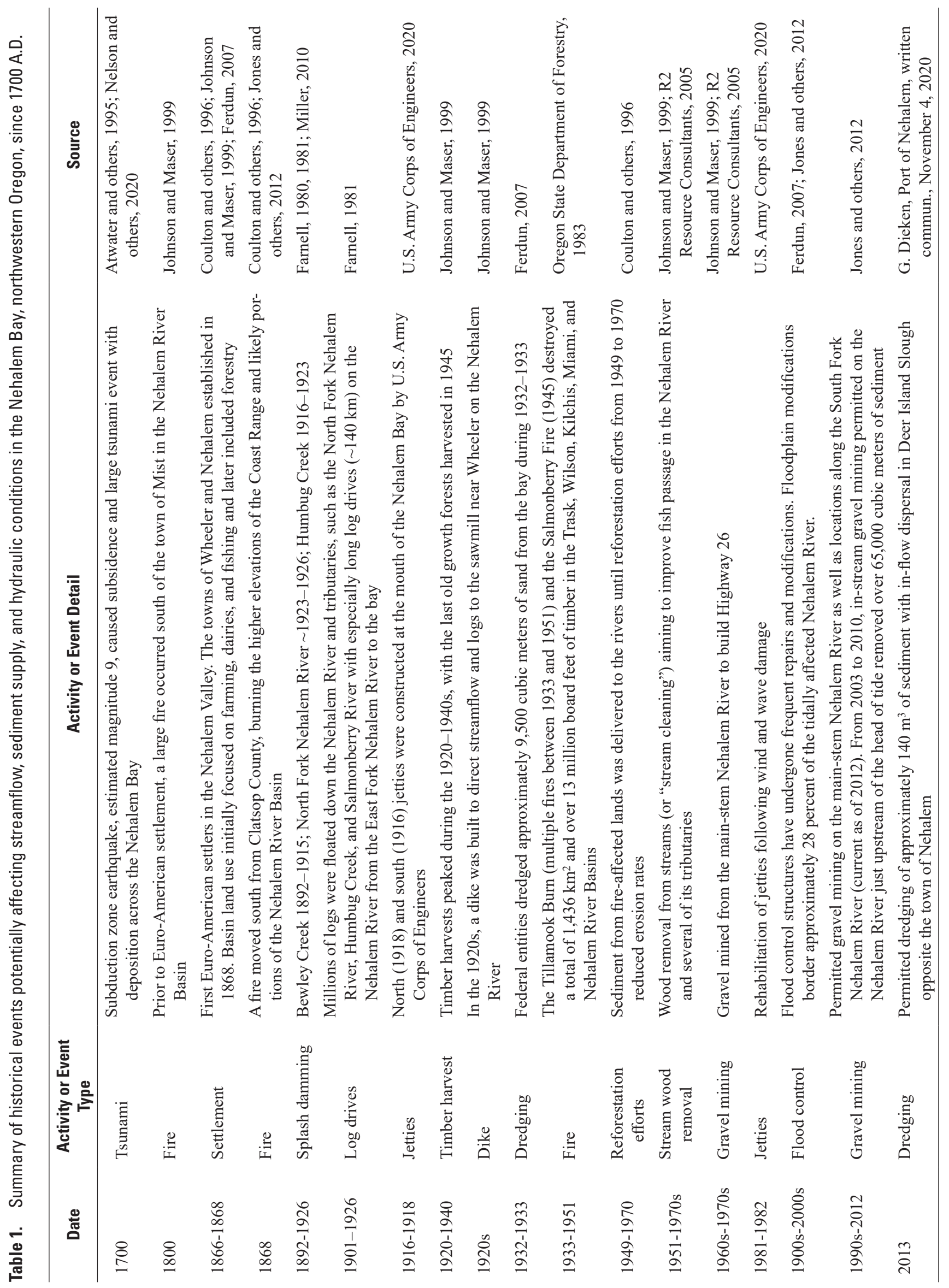


The hydrology of the basin is driven by seasonal precipitation that falls mainly from October to March; mean annual precipitation ranges from 241 centimeters $(\mathrm{cm})$ near the Nehalem Bay to $508 \mathrm{~cm}$ in the Salmonberry River Basin (Johnson and Maser, 1999). Mean annual streamflow from water years (WY; the WY extends from October 1 through September 30 and is named for the calendar year in which it ends) 1940 to 2019 is 75 cubic meters per second ( $\mathrm{m}^{3} / \mathrm{s} ; 2,660$ cubic feet per second $\left[\mathrm{ft}^{3} / \mathrm{s}\right]$; USGS streamflow-gaging station, Nehalem River near Foss, 14301000; U.S. Geological Survey, 2020; fig. 1). Peak streamflows on the Nehalem River near Foss reached 1,990 m³/s $\left(70,300 \mathrm{ft}^{3} / \mathrm{s}\right)$ on February 8, 1996. The number of streamflow events exceeding the flood value associated with the 0.2 annual exceedance probability (AEP, sometimes referred to as the five-year recurrence interval; $1,028 \mathrm{~m}^{3} / \mathrm{s}\left[36,500 \mathrm{ft}^{3} / \mathrm{s}\right]$ for the Nehalem River near Foss) increased from WY 1964 to 2012 (Jones and others, 2012). AEP is the probability of the largest flood of the year being equal to or greater than a given value for any given year. For example, a 0.2 AEP flood for any given year has a 20 percent chance that the largest streamflow of the year will be equal to or greater than that value.

\section{Nehalem Bay}

This study assesses bathymetric changes for a 14-kmlong section of the Nehalem Bay, encompassing the area from the confluence of the Nehalem and North Fork Nehalem Rivers to the Pacific Ocean, where historical bathymetric datasets were available (fig. 2). This section of the Nehalem River flows over alluvial deposits through unconfined and confined valley segments (Jones and others, 2012). From Rkm 24.6 (east of fig. 2 map extent) downstream to the mouth of the Nehalem River, the width of the floodplain ranges from 340 to 4,720 meters $(\mathrm{m})$. A few small bars (with a maximum area of $0.09 \mathrm{~km}^{2}$ in 2009) flank the channel in the upper section of this reach, whereas tidal flats and islands (with a maximum area of $4.7 \mathrm{~km}^{2}$ in 2009) are present in the Nehalem Bay (Jones and others, 2012). The Nehalem Bay is locally constrained by floodplain modifications (such as roads, revetments, and human-made dikes) and natural levees and by jetties at the mouth (fig. 2; Jones and others, 2012).

Water levels in the Nehalem Bay are affected by tide and streamflow. Tide levels in the Bay vary by nearly $3.2 \mathrm{~m}$ (minimum and maximum values range from about -0.4 to $2.7 \mathrm{~m}$ relative to mean lower low water [MLLW] based on 2019 predictions at National Oceanic and Atmospheric Administration (NOAA) Nehalem station 9437908; fig. 2). Actual tide measurements in the Nehalem Bay were made during brief periods in the 1930s and 1950s at the Brighton (9437815), Wheeler (9437858), and Nehalem (943708) tide stations (fig. 2; table 2). The Nehalem and Brighton tide stations are subordinate stations with tide-level predictions based on gaged data at the Crescent City, California, station (9419750; not shown on figures). More recently, a short-term tide gage on the North Fork Nehalem River (9437954) recorded data from June to October 2017. Current tide-level predictions are based on gaged data at Garibaldi, Oregon (9437540), to the south in the Tillamook Bay. 


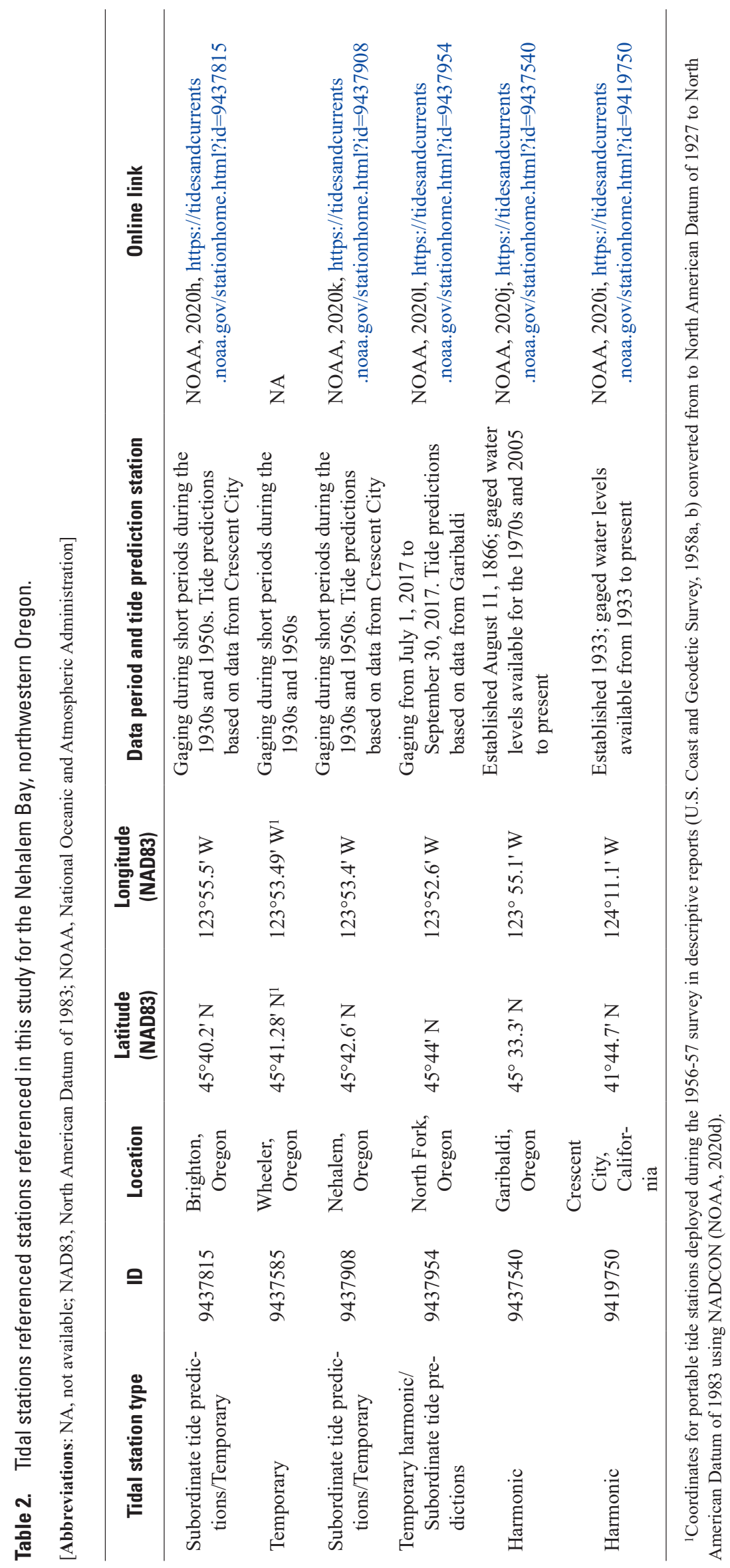




\section{Study Methods}

This study quantifies and documents long-term historical bathymetric changes in the Nehalem Bay by comparing multiple bathymetric datasets, including nautical charts published by the U.S. Coast and Geodetic Survey (USCGS; until 1970) and National Ocean Service (NOS; after 1970; National Oceanic and Atmospheric Administration [NOAA], 2020c) from 1891 to 2004 (National Oceanic and Atmospheric Administration, 2020b), bathymetric surveys collected by the USCGS in 1868 (National Oceanic and Atmospheric Administration, 2020a) and 1956-57 (herein 1957 survey; USCGS, 1958a, b, National Oceanic and Atmospheric Administration, 2020a), and a recent bathymetric survey collected by the U.S. Geological Survey (USGS) in summer 2019 (Gordon and others, 2020a, b; table 3; app. 2). The datasets varied in their spatial coverages of the Nehalem Bay, spatial resolution (or the density of soundings or water depth measurements), level of uncertainty related to the methods of collecting the depth measurements, data processing in preparation for analyses, and the analyses themselves. Generally, the available bathymetry datasets can be divided into two categories: (1) relatively higher-resolution bathymetric surveys from 1868, 1957 and 2019, and (2) relatively lower-resolution nautical charts with limited spatial coverage of the Nehalem Bay (1891-2012; fig. 4). For example, the bathymetric survey from 1957 had a sounding density of about 1,270 points $/ \mathrm{km}^{2}$ with a typical point spacing of $15-31 \mathrm{~m}$. The survey from 2019 had a sounding density of about 12,600 points $/ \mathrm{km}^{2}$ with a typical point spacing of $1.5-31 \mathrm{~m}$. In contrast, the nautical charts had a sounding density of 40 points $/ \mathrm{km}^{2}$ and a typical point spacing of 61-180 m. Also, nearly all the nautical charts are a combination of data from prior surveys and new depth data collected in different parts in the Nehalem Bay. The spatial resolution of the bathymetric surveys and nautical charts for the Nehalem Bay is relatively low compared with that achieved by high-resolution survey techniques used in other estuaries, lakes, rivers, and parts of the ocean (such as multibeam sonar surveys that can produce more than 100 times the soundings as single beam sonar over the same survey time; L-3 Communications SeaBeam Instruments, 2000).

Two approaches were used to document and describe the magnitudes and patterns of bathymetric changes in the Nehalem Bay: (1) comparison of changes in bed elevation (relative to NAVD 88 vertical datum) with estimated volumes of erosion and deposition from the survey data acquired in 1957 and 2019 and (2) analyses of the distribution of water depth values (relative to MLLW vertical datum) from nautical charts spanning 1891 to 2004 for seven distinct areas (or zones) of the Nehalem Bay (figs. 4, 5). These two approaches were used because: (1) the bathymetric surveys from 1957 and 2019 could be tied to a common vertical datum for a direct comparison of bed elevations and (2) the nautical charts could not be tied to a common vertical datum as MLLW has varied over time, thereby limiting the analyses to a comparison of water depths over a broader time frame. The following sections describe the existing and newly acquired bathymetric datasets underlying this study and the methods for the two approaches for evaluating bathymetric change.

Table 3. Summary of nautical charts and bathymetric data for the Nehalem Bay, northwestern Oregon, evaluated for this study.

[Vertical datum: MLLW datum has varied over time. Horizontal datum: Clarke 1866 assumed horizontal datum based on maps typical of the period. Abbreviations: NA, not applicable (data not available or unknown); NAD 27, North American Datum of 1927; NAD 83, North American Datum of 1983; MLLW, mean lower low water; NAVD 88, North American Vertical Datum of 1988; USGS, U.S. Geological Survey]

\begin{tabular}{lccccc}
\hline \multicolumn{1}{c}{ Dataset } & $\begin{array}{c}\text { Publication } \\
\text { (and acquisition) } \\
\text { year }\end{array}$ & $\begin{array}{c}\text { Chart } \\
\text { edition }\end{array}$ & $\begin{array}{c}\text { Chart } \\
\text { number }\end{array}$ & $\begin{array}{c}\text { Horizontal } \\
\text { datum }\end{array}$ & $\begin{array}{c}\text { Vertical } \\
\text { datum }\end{array}$ \\
\hline Historical nautical charts & & & \\
\hline Navigation chart for the Nehalem River & 1891 & NA & 6122 & NA & MLLW \\
Nehalem River nautical chart & 1947 & NA & 6122 & NAD 27 & MLLW \\
Nehalem River nautical chart & 1970 & 20 & 6122 & NAD 27 & MLLW \\
Nehalem River nautical chart & 1973 & 21 & 6122 & NAD 27 & MLLW \\
Nehalem River nautical chart & 1982 & 23 & 18556 & NAD 27 & MLLW \\
Nehalem River nautical chart & 1978 & 22 & 18556 & NAD 27 & MLLW \\
Nehalem River nautical chart & 1990 & 24 & 18556 & NAD 83 & MLLW \\
Nehalem River nautical chart & 2004 & 25 & 18556 & NAD 83 & MLLW \\
Nehalem River nautical chart & 2012 & 26 & 18556 & NAD 83 & MLLW \\
\hline & Bathymetric surveys & & & \\
\hline USCGS survey & NA (1868) & NA & NA & Clarke 1866 & MLLW \\
USCGS survey & $1958(1956-57)$ & NA & NA & NAD 27 & MLLW \\
USGS survey & $2020(2019)$ & NA & NA & NAD 83 & NAVD 88 \\
\hline
\end{tabular}




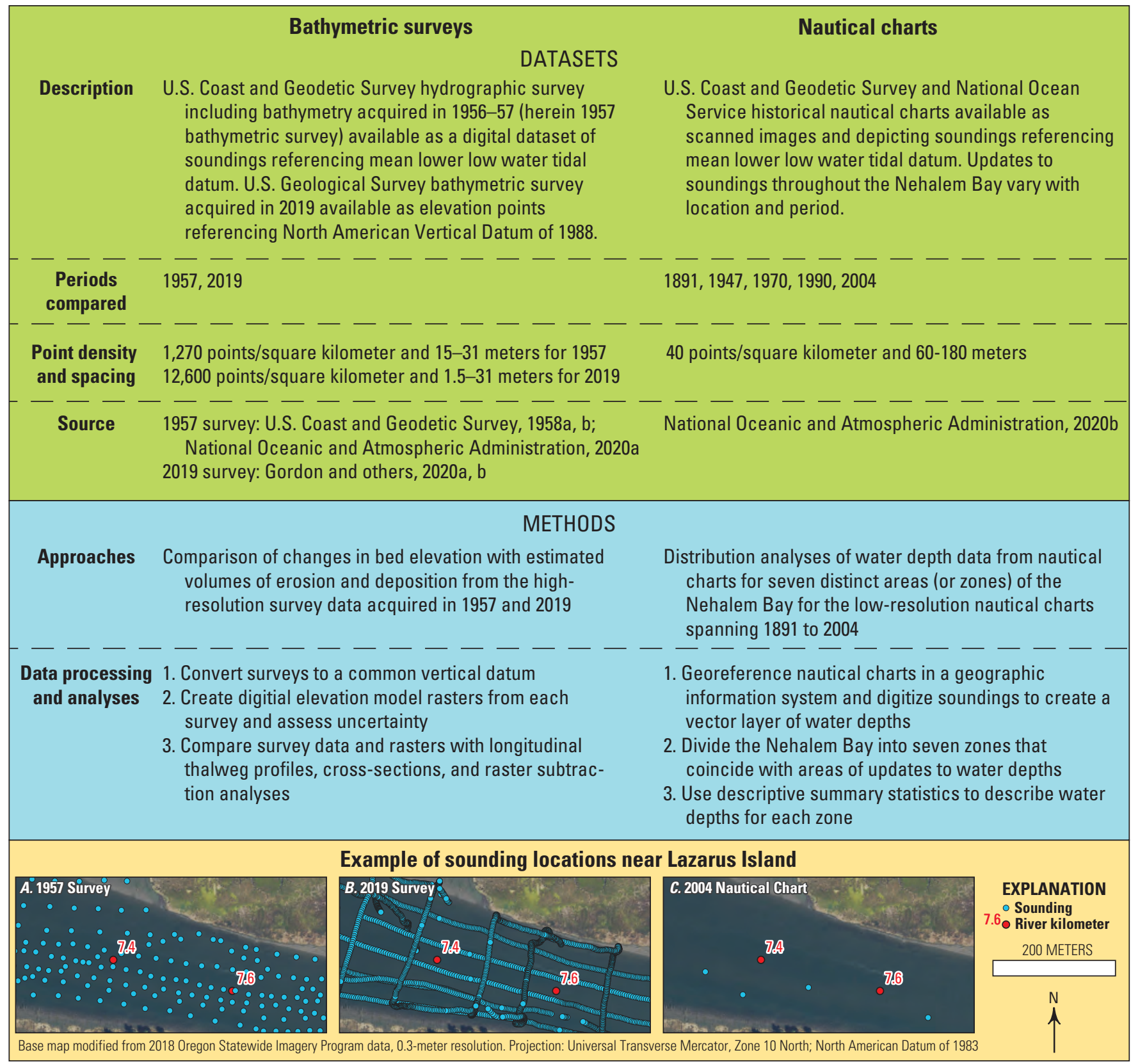

Figure 4. Diagram outlining the datasets analyzed and the study's approaches for (1) processing and evaluating changes in bed elevation from survey data collected by the U.S. Coast and Geodetic Survey in 1956-57 (1958a, b, downloaded from National Oceanic and Atmospheric Administration, 2020a) and the U.S. Geological Survey in 2019 (Gordon and others, 2020a, b) and (2) processing and evaluating changes in water depth using the nautical charts from the U.S. Coast and Geodetic Survey and National Ocean Service (downloaded from National Oceanic and Atmospheric Administration, 2020b).

\section{Review of Bathymetry Data}

\section{Historical Nautical Charts, 1891-2012}

Nine nautical charts spanning 121 years (1891-2012) were downloaded from the Office of the Coast Survey's historical map and chart database (National Oceanic and Atmospheric Administration, 2020b) in jpeg format (table 3). The 1:20,000-scale charts typically encompass the Nehalem Bay from the area near the confluence of the North Fork and main-stem Nehalem Rivers to the off-shore area beyond the
Nehalem Bay; although no coverage upstream of the Highway 101 bridge (Rkm 10.6; fig. 2) was available for the 1891 and 1947 charts. Despite the availability of multiple nautical chart publications since 1970 , most of the source bathymetry in the study area is based in part on the survey data from 1957 (described in the following section). Updates to depths throughout the Nehalem Bay are evident in the charts from 1891, 1947, 1970, 1990, 2004, and therefore, these charts were used in the analyses in this study (described under "Comparison of Changes in Water Depths from the Nautical Charts, 1891 to 2004”). 


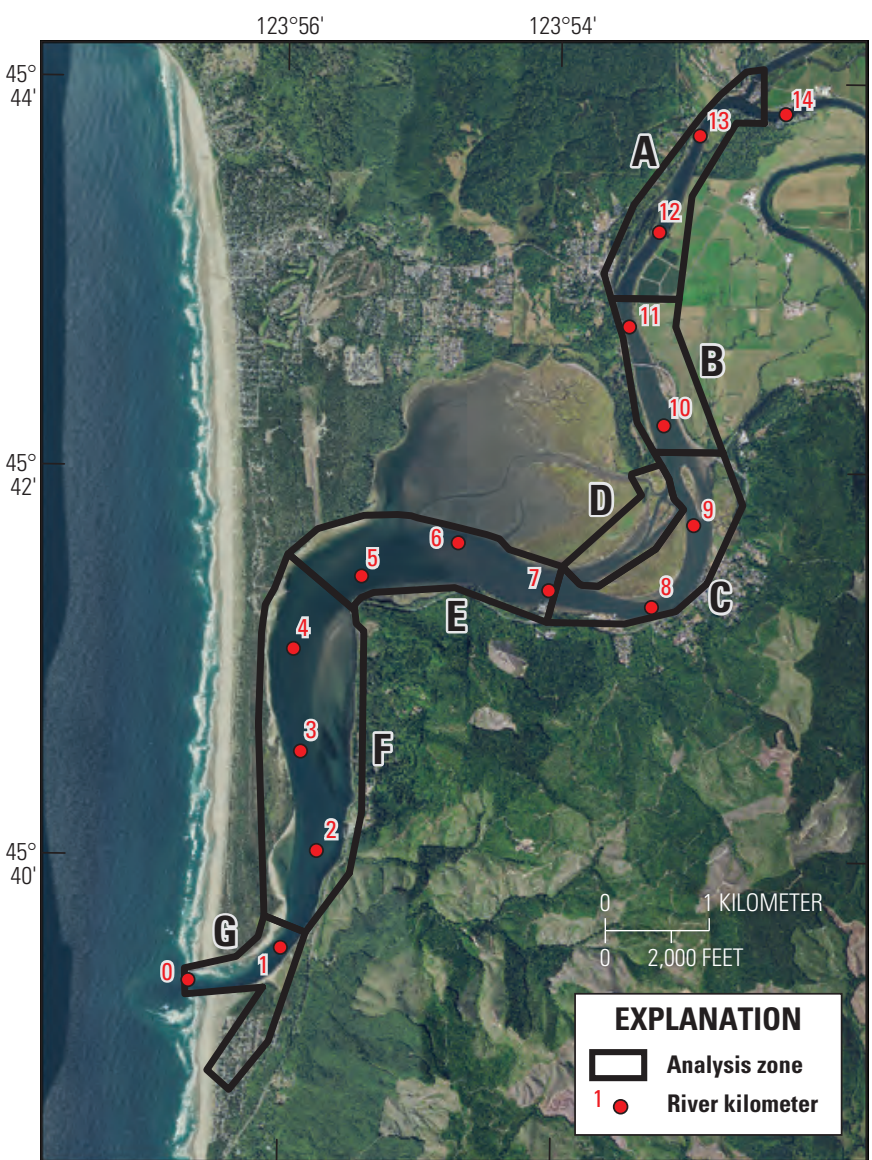

Base map modified from 2018 Oregon Statewide Imagery Program data, 0.3-meter resolution. Projection: Universal Transverse Mercator, Zone 10 North; North American Datum of 1983

Figure 5. Zones in the Nehalem Bay, northwestern Oregon, in which changes in water depth from 1891 through 2004 were evaluated. Zone A extends from river kilometer (Rkm) 13.6 to 11.3; Zone B from Rkm 11.3 to 9.7; Zone C from Rkm 9.7 to 7.1; Zone D from Rkm 9.6 to7.2 along Lazarus Island Slough; Zone E from Rkm 7.1 to 4.7, Zone F from Rkm 4.7 to 1.2; and Zone G from Rkm 1.2 to 0.

Bathymetric data within the charts selected for this study are represented as sounding points spaced from about 60 to $180 \mathrm{~m}$ apart or contour lines of depth referenced to the MLLW tidal datum as the vertical datum. Tidal datums have changed over time and are calculated from 19-year tidal cycles called National Tidal Datum Epochs. The present epoch spans the years 1983 to 2001 and went into effect in 2003 (National Oceanic and Atmospheric Administration, 2003; fig. 6). Though water depths depicted on all nautical charts reference MLLW, historical tidal datums in the Nehalem Bay are unknown because of the lack of active or historical long-term tide gaging-stations. Some charts also contain data documenting heights referenced to the mean high water (MHW) tidal datum; however, height points within the main area of analysis were few and mostly limited to rock outcrops near the river entrance, and are not included in analyses for this study. The most recent and most frequently updated data points in the charts are in the off-shore areas west of longitude $123^{\circ} 57^{\prime} \mathrm{W}$, outside of the study area. The horizontal datum of the 1891 chart was assumed to be Clarke 1866 based on maps typical of the same period. Horizontal datums include the North American Datum of 1927 (NAD27) for the charts from 1947 and 1970 and the North American Datum of 1983 (NAD83) for the charts from 1990, 2004, and 2012. A summary of horizontal and vertical datum for each data source is included in table 3 .

\section{Hydrographic Surveys, 1868 and 1956-57}

Historical hydrographic surveys acquired by the USCGS were used to make "smooth sheets," or maps of soundings, shorelines, and geographic, navigational, and other features (Zimmerman and Benson, 2013). These sheets are maintained by the National Centers for Environmental Information (available from the NOS Hydrographic Data Base with Hydrographic Survey Meta Data Base; National Oceanic and Atmospheric Administration, 2020a). Scanned smooth sheets for the Nehalem Bay were available for 1868 and 1957 as non-georeferenced images.

Of these two hydrographic surveys, only the survey from 1957 was suitable for comparisons with a recent bathymetric survey from 2019 (described in "Comparison of Changes in Bed Elevations using Bathymetry from Bathymetric Surveys, 1957 and 2019"). The survey from 1868 lacked the information necessary to: (1) accurately georeference the map (for example, latitude and longitude marks and distinct topographic features) and (2) convert the soundings to a common vertical datum for comparison with the 2019 survey acquired for this study. The 1957 survey was available as a text file (National Oceanic and Atmospheric Administration, 2020a) with its horizontal coordinates updated by the NOS to the NAD83 datum. Soundings were made relative to the MLLW vertical datum using portable tide gages near Nehalem, Wheeler, and Brighton that were tied into local benchmarks (fig. 2; table 2). Benchmarks are markers or monuments in fixed locations that have known horizontal and vertical coordinates.

The 1957 survey comprised two commissioned surveys by the USCGS (H-8368 and H-8369), accompanied by descriptive reports summarizing the surveys, datums, uncertainties, and other details of the data collection (U.S. Coast and Geodetic Survey, 1958a, b). The H-8369 survey encompassed the area from Fishery Point upstream to the confluence of the Nehalem River with the North Fork Nehalem River and was conducted in October and November 1956. The H-8368 survey encompassed the Nehalem River entrance upstream to Fishery Point and was conducted between June and July 1957. Bathymetric data were acquired using a fathometer (a type of sonar) and pole in a skiff with at a point sounding spacing ranging from about 15 to $31 \mathrm{~m}$, and horizontal positions were determined by sextant angles between targets on the shore that had been located prior to the survey. The USCGS assumed a maximum vertical uncertainty of $0.3 \mathrm{~m}$ for all survey depths, based on reported variation between surveyed values and values plotted on the smooth sheets (U.S. Coast and Geodetic Survey, 1958a, b). 


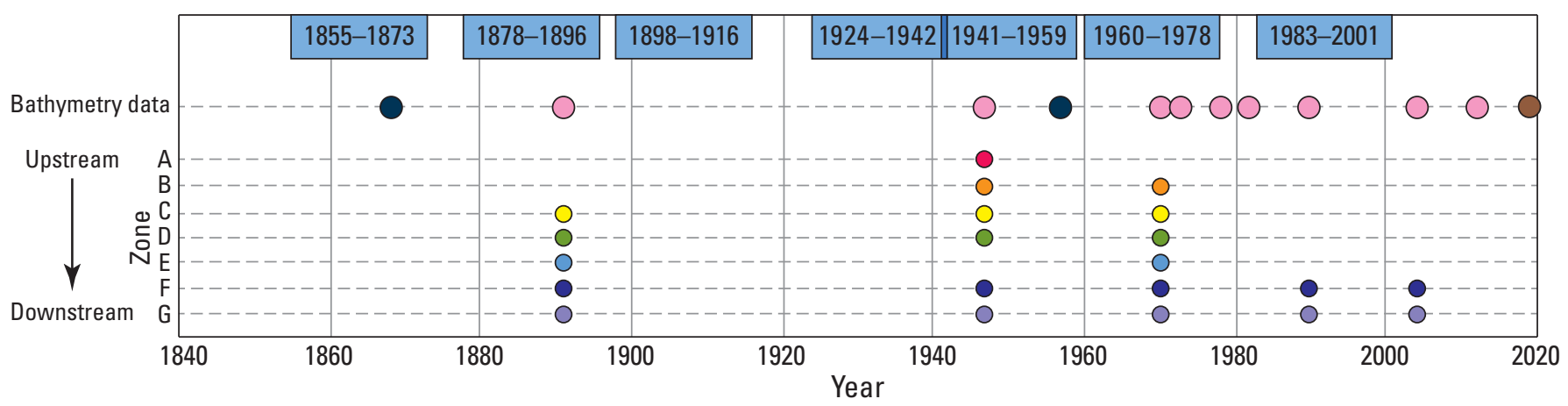

EXPLANATION

\begin{tabular}{|ll}
\hline & U.S. Coast and Geodetic Survey bathymetric survey \\
\hline & U.S. Geological Survey bathymetric survey \\
Nautical chart publications \\
0 & Zone A updates \\
\hline & Zone B updates \\
0 & Zone C updates \\
0 & Zone D updates \\
\hline & Zone E updates \\
\hline & Zone G updates \\
\hline & 19-year epoch
\end{tabular}

Figure 6. Timeline of datasets, reference datums, and updates to bathymetry and nautical charts for distinct areas, or zones, of the Nehalem Bay. These zones are described in more detail in the "Depth Distribution Analyses" section of this report.

\section{Bathymetry Acquired in 2019}

Bathymetric data were collected as part of this study in summer 2019 for approximately $2.2 \mathrm{~km}^{2}$ of the Nehalem Bay between Rkm 10.8 (upstream of the Highway 101 bridge, Rkm 10.6) and Fishery Point (Rkm 4.4) (Gordon and others, 2020a, b). Water depths were measured with a single-beam sonar (Seafloor Systems HydroLite-TM, Seafloor Systems, Inc., Shingle Springs, California). Horizontal and vertical coordinates of the transducer position (relative to NAD83 and NAVD 88) were recorded with real-time kinematic geographic positioning systems (RTK-GPS, Trimble R8, Trimble, Inc., Sunnyvale, Calif.). Bed elevations were calculated by subtracting the sonar-derived water depth from the recorded vertical position of the navigation system. Data were collected in streamwise transects spaced approximately 20 to $50 \mathrm{~m}$ apart, similar to that in the hydrographic survey of 1957, and in transects perpendicular to the channel with 50-100 m spacing.

Vertical accuracy of bed elevations is a function of the accuracy of both the sonar-derived water depth and that of the surveyed position. Raw sonar data assume a consistent sound velocity, which can be affected by salinity and water temperature. To assess potential variation, sound-velocity profiles were recorded at 19 different locations evenly spaced throughout the survey area to quantify the spatial and temporal variation in the speed of sound and to correct water-depth measurements during survey post-processing. Final bed elevation values had a mean vertical uncertainty of $4.1 \mathrm{~cm}$ and a mean horizontal uncertainty of about $1.0 \mathrm{~cm}$ (Gordon and others, 2020b). Detailed information regarding data collection, processing, and error calculations can be found in Gordon and others $(2020 \mathrm{a}, \mathrm{b})$. In addition to the uncertainty associated with survey measurements quantified by Gordon and others (2020a, b), vertical accuracy is also affected by boat draft, platform stability, boat velocity, and subsurface material density (Wilson and Richards, 2006), though these factors were not quantified. Therefore, application of a more conservative estimate of vertical accuracy was assumed for the survey (10 cm; typical of single-beam sonar surveys) and carried through the analyses.

\section{Comparison of Changes in Bed Elevations from Bathymetric Surveys, 1957 and 2019}

Quantitative analyses of bed-elevation change were completed by converting the bathymetry from the surveys completed in 1957 and 2019 to a common vertical datum. The resulting survey maps (with bed elevations represented as points) were then converted to digital elevation models (DEM; rasters) of bed elevation (with elevations assigned to each grid cell). Overlaying the survey rasters provides a basis for assessing spatial patterns of erosion, deposition, and planform channel change where overlap occurs between the DEMs. For this study, comparisons were possible for the area of the Nehalem Bay between Rkm 10.8 and 4.4 (upstream of the Highway 101 bridge to about Fishery Point; fig. 2). The following sections describe these methods. 


\section{Conversion to a Common Vertical Datum}

To evaluate bathymetric changes between the 1957 and 2019 datasets, survey data must be referenced to a common vertical datum. Because the 1957 (U.S. Coast and Geodetic Survey, 1958a, b) and 2019 (Gordon and others, 2020b) surveys had different vertical datums (MLLW measured during the survey and NAVD88 Geoid 12b, respectively), the vertical datum of the 1957 survey was converted to match that of the 2019 survey. To make this conversion, the soundings from both surveys were directly imported to ArcGIS (version 10.8). Data from the 1957 survey referencing measured tide levels at temporary tide stations near Nehalem, Wheeler, and Brighton (fig.2; table 2) were then converted to the present-day MLLW datum using the local benchmarks referenced in the descriptive reports (U.S. Coast and Geodetic Survey, 1958a, b) and NOAA's VDatum tool (National Oceanic and Atmospheric Administration, 2020e; table 4).

The MLLW value on the staff at each temporary tide station also included a vertical distance below a local benchmark at the time of the 1957 survey. These benchmark elevations (in NAVD88) were converted to present-day MLLW, then the difference between the present-day benchmark MLLW elevations and the respective distance below the benchmark of the MLLW staff value at each tide station of the 1957 survey was calculated to determine adjustments for the 1957 survey data. These adjustments were $0.47 \mathrm{~m}$ at Nehalem, $0.15 \mathrm{~m}$ at Wheeler, and $0.20 \mathrm{~m}$ at Brighton (table 4). The Brighton gage adjustment was used for all data in the H-8368 survey. For H-8369, the survey data referenced multiple gages (Nehalem and Wheeler) and multiple periods (1956 and 1957; see the "Hydrographic Surveys, 1868 and 1956-57" section). All survey points upstream of the north end of the Snag Island at latitude 454'05.37' (NAD83) referenced the Nehalem gage, and all points downstream reference the Wheeler gage (U.S. Coast and Geodetic Survey, 1958b); adjustments to present day MLLW were made by subtracting $0.47 \mathrm{~m}$ from the points referencing the Nehalem station (table 4). The Wheeler gage was deployed and used as a survey datum in both the fall of 1956 and the summer of 1957. Information was not available to identify which H-8369 survey soundings reference the Wheeler gage by date. MLLW changed by about $0.15 \mathrm{~m}$ between the two seasons. We applied the 1957 adjustment for the Wheeler station (subtract $0.15 \mathrm{~m}$ ) to all data downstream of $45^{\circ} 42^{\prime} 05.37^{\prime \prime}$ (table 4), using the assumption that more data were collected during the longer summer surveying period. Because the surveyed depths upstream and downstream of $45^{\circ} 42^{\prime} 05.37^{\prime \prime}$ referenced two different gages and therefore benchmarks for MLLW, an abrupt change in bed elevations at the upstream end of Snag Island could occur in the original and adjusted survey datasets. When the original and adjusted survey datasets were reviewed, however, no abrupt shifts were found in the original depth points, converted elevation points, or the resulting digital elevation model (described in the following section "Raster Creation and Associated Uncertainty"). Once all data points referenced the present-day MLLW, they were transformed to NAVD88 Geoid 12b using NOAAs VDatum tool, which was created to vertically transform geospatial data among a variety of datums (National Oceanic and Atmospheric Administration, 2020e). This vertical transformation of the 1957 data introduced an additional $0.22 \mathrm{~m}$ of uncertainty (determined with the VDatum tool).

\section{Raster Creation and Associated Uncertainty}

Raster DEMs of the 1957 and 2019 surveys were created to interpolate bed elevations between measured points and to support the quantitative analyses of bed-elevation changes. Survey points of bed elevation were used to create a triangular irregular network (TIN) surface in ArcGIS. Manually digitized breaklines representing breaks in slope were added in locations where the TIN interpolation produced obvious errors in the resulting bathymetric surface, such as erroneous high areas that crossed the channel thalweg or where shallow areas that gradually transition to deeper parts of the bay should be more distinct. The edited TIN was converted into a DEM raster with a 20-m cell size. Raster cell size was determined from the number of observations across the survey area (Hengl, 2006) and then increased to account for point spacing within surveys.

Overall DEM uncertainty values were estimated by combining error and uncertainty values from the survey vertical accuracy, tidal datum conversions, and the standard deviation of error from DEM interpolation (table 5). Interpolating surveyed depths to create a continuous DEM introduces error in the bathymetric datasets (for example, see Fisher and Tate, 2006, and Wheaton and others, 2010). The mean error (ME) for each DEM related to interpolation was calculated with:

where

$$
M E=\frac{\sum\left(Z_{D E M(i)}-Z_{R e f(i)}\right)}{n},
$$

\footnotetext{
$Z_{D E M(i)} \quad$ is the measurement of elevation from the DEM,

$Z_{\text {Ref(i) }} \quad$ is the survey elevation, and

$n$ is the number of bed elevation points used to create the DEM.
} 


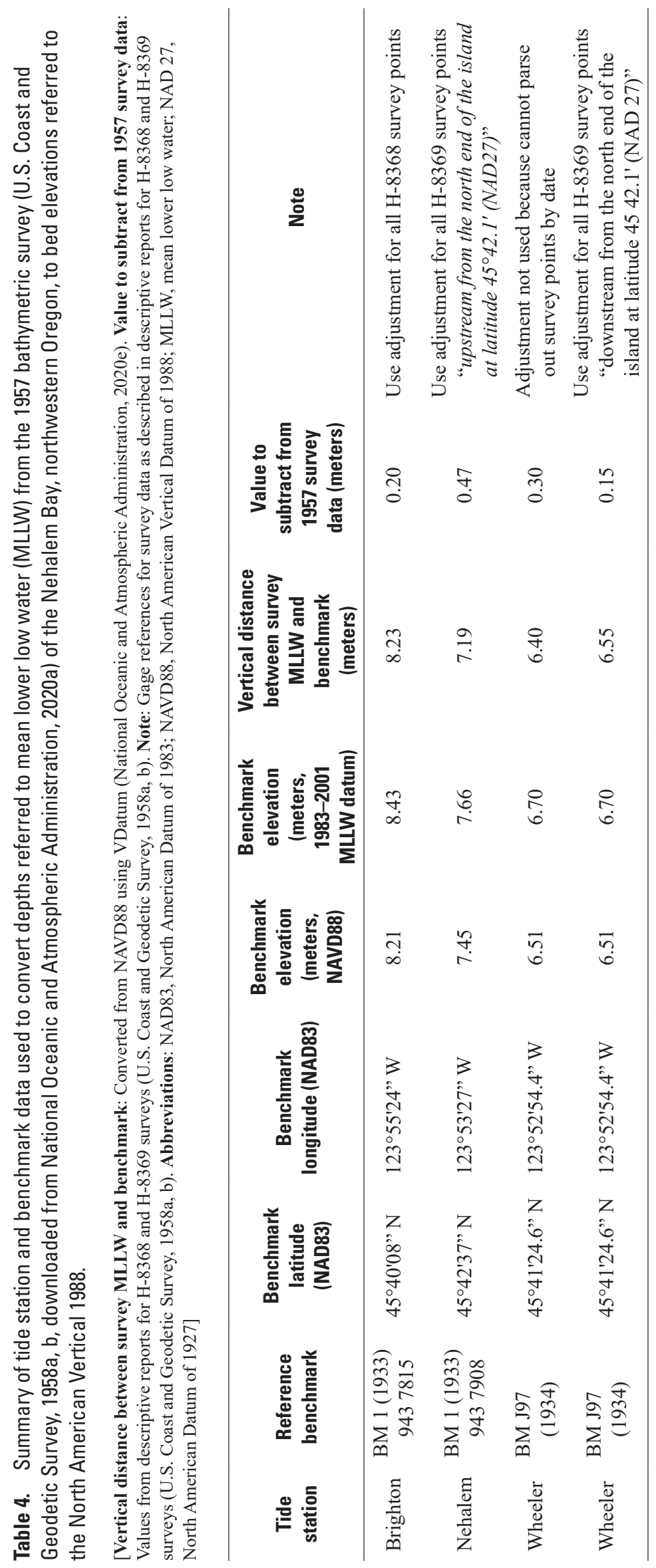


Table 5. Digital elevation model uncertainty for 1957 (U.S. Coast and Geodetic Survey, 1958a, b; National Oceanic and Atmospheric Administration, 2020a) and 2019 bathymetric surveys (Gordon and others, 2020b) of the Nehalem Bay, northwestern Oregon.

[Values are in meters. Abbreviations: MLLW, mean lower low water; NA, not applicable; NAVD 88, North American Vertical Datum of 1988; DEM, digital elevation model]

\begin{tabular}{lccc}
\hline \multicolumn{1}{c}{ Survey } & Notation used in report & $\mathbf{1 9 5 7}$ & $\mathbf{2 0 1 9}$ \\
\hline Survey vertical accuracy & $\mathrm{a}$ & 0.30 & 0.10 \\
Vertical datum conversion (1957 MLLW to present-day MLLW) & $\mathrm{b}_{1}$ & 0.15 & $\mathrm{NA}$ \\
Vertical datum conversion (present-day MLLW to NAVD88) & $\mathrm{b}_{2}$ & 0.22 & $\mathrm{NA}$ \\
Mean error from DEM interpolation & $\mathrm{ME}$ & 0.01 & -0.02 \\
Standard deviation of error from DEM interpolation & $\mathrm{S}$ & 0.28 & 0.36 \\
Total DEM uncertainty (sum of squares) & DEM uncertainty & 0.50 & 0.37 \\
\hline
\end{tabular}

Uncertainty related to DEM interpolation, taken as the error standard deviation or $S$, for each DEM was then calculated with:

$$
S=\sqrt{\frac{\left.\sum_{[}\left(Z_{D E M(i)}-Z_{R e f(i)}\right)-M E\right]^{2}}{n-1}}
$$

$S$ values are $0.28 \mathrm{~m}$ for 1957 and $0.37 \mathrm{~m}$ for 2019 (table 5).

Then, the sum of squares was used to quantify the total uncertainty associated with each DEM (DEM uncertainty):

$$
\text { DEM uncertainty }=\sqrt{\left(a^{2}\right)+\left(b_{1}^{2}\right)+\left(b_{2}^{2}\right)+\left(S^{2}\right)},
$$

where

$a \quad$ is the total vertical uncertainty associated with each survey $(0.30 \mathrm{~m}$ for 1957 ["Hydrographic Surveys, 1868 and 1956-57"] and $0.10 \mathrm{~m}$ for 2019 ["Bathymetry Acquired in 2019 for this Study"]), and

$b_{1}, b_{2}$ are the uncertainties associated with the datum conversions $(0.15$ and $0.22 \mathrm{~m}$ for 1957 ["Conversion to Common Vertical Datum"]; not applicable for 2019).

Total DEM uncertainty (DEM uncertainty), including vertical accuracy, tidal datum conversions, and the standard deviation of error from DEM interpolation, was calculated as $0.50 \mathrm{~m}$ for 1957 and $0.37 \mathrm{~m}$ for 2019 (table 5).

\section{Bed-Elevation Change Analyses}

Changes in bed elevation between 1957 and 2019 were assessed for areas where the surveys and DEMs overlapped on the basis of longitudinal profiles of the channel thalweg, cross sections, and DEMs of difference (created by subtracting the 1957 DEM from the 2019 DEM). Thalwegs for the
1957 and 2019 surveys were digitized in ArcGIS, and bed elevations were extracted every $20 \mathrm{~m}$ from the respective DEMs. Those values were aligned with the closest $\mathrm{Rkm}$ from the 2009 wetted-channel centerline linear referencing system so that the two sets of thalweg values used the same linear reference system for comparison of the longitudinal profiles. Cross sections were digitized at nine representative locations throughout the Nehalem Bay that encompass different features (such as single channel segments, segments with islands, or segments adjacent to mudflats). Bed elevations from survey points located within $20 \mathrm{~m}$ of the cross section were extracted to examine differences between the two periods.

DEMs of difference in bed elevation between 1957 and 2019 were generated using Geomorphic Change Detection software (GCD 7.4.4.0; Riverscapes Consortium, 2019). This approach subtracts the 1957 bed elevations from the 2019 bed elevations, resulting in a dataset that shows spatial patterns of erosion, deposition, and planform channel change at the scale of a 20-m DEM cell size. To ensure direct comparison between the two survey datasets, the processing extent of both rasters was reduced to overlapping pixels. To differentiate actual changes between surveys from changes associated with survey uncertainty or errors in DEM interpolation, a probabilistic thresholding approach was applied using 75 -percent and 95-percent confidence intervals, where the confidence interval is the range of values in which the true value of bed elevation change is likely to occur. Uniform error rasters for each DEM were determined from the combination of survey uncertainty, datum conversions, and DEM interpolation (see the previous section, "Raster Creation and Associated Uncertainty"). These error rasters were used to remove estimated changes below an expected detectable limit using probability confidence interval thresholds. The result of this calculation is that any changes less than the detection limit are assumed to be zero, although this process might also remove real change that falls below the detectable limit. Although we applied uniform error estimates 
to the survey DEMs, uncertainty in DEM interpolation is most likely greater in steep areas, such as along channel margins and banks and in areas with lower point density (Wheaton, 2008; Wheaton and others, 2010; Hempel, 2020).

\section{Comparison of Changes in Water Depths from Nautical Charts, 1891-2004}

\section{Conversion to Vector Digital Data}

Depths depicted on USCGS nautical charts were converted to spatial point shapefiles by georeferencing each chart and then digitizing depths indicated on the charts. Latitude and longitude shown on the charts were used as the primary georeferencing control points. Secondary control points, such as road intersections, were matched between charts with a common horizontal datum. For example, the 1947 chart was georeferenced using only marked intersections of latitude and longitude, and subsequent charts using NAD27 were georeferenced using those same marks along with point features common between charts. The charts had a mean of 17 control points and used a first-order transformation (shifting, scaling, and rotating the chart to achieve alignment with locations of geographic features) with a mean root mean square error of $2.2 \mathrm{~m}$ ( $\pm 0.8 \mathrm{~m}$, standard deviation). All charts were converted to a common horizontal datum (NAD83). Once georeferenced, soundings depicted on the charts were digitized within the study area.

\section{Depth Distribution Analyses}

The nautical charts from 1891 to 2004 could not be converted to a common vertical datum (such as NAVD88 or present-day MLLW), owing to the lack of active or historical long-term tide gaging-stations in the Nehalem Bay to estimate the MLLW datum elevations for previous tidal epochs and necessary descriptive data for the surveys. Additionally, the frequency of depth updates varied throughout the Nehalem Bay; some areas (such as zone A) included new bathymetry only in the 1970 nautical chart whereas other areas (such as zones F and G) included new bathymetry in the 1891, 1947, 1970, 1990, and 2004 charts (figs. 5 and 6). Despite the limitations of the nautical charts, they contain information useful for examining changes in water depth in parts of the Nehalem Bay over a broader time frame than what can be examined using the bathymetric surveys. Thus, historical changes in water depth soundings depicted by these charts were evaluated by assessing spatial and temporal changes in water depths.
Given the partial coverages of these nautical charts, the Nehalem Bay was divided into seven distinct areas, or zones (fig. 5), for this analysis. These zones were delineated on the basis of where some bathymetric data had been updated between nautical chart publications. Zones range in length from about 1.2 to $3.5 \mathrm{~km}$ and were named A through $\mathrm{G}$ from upstream to downstream for this study.

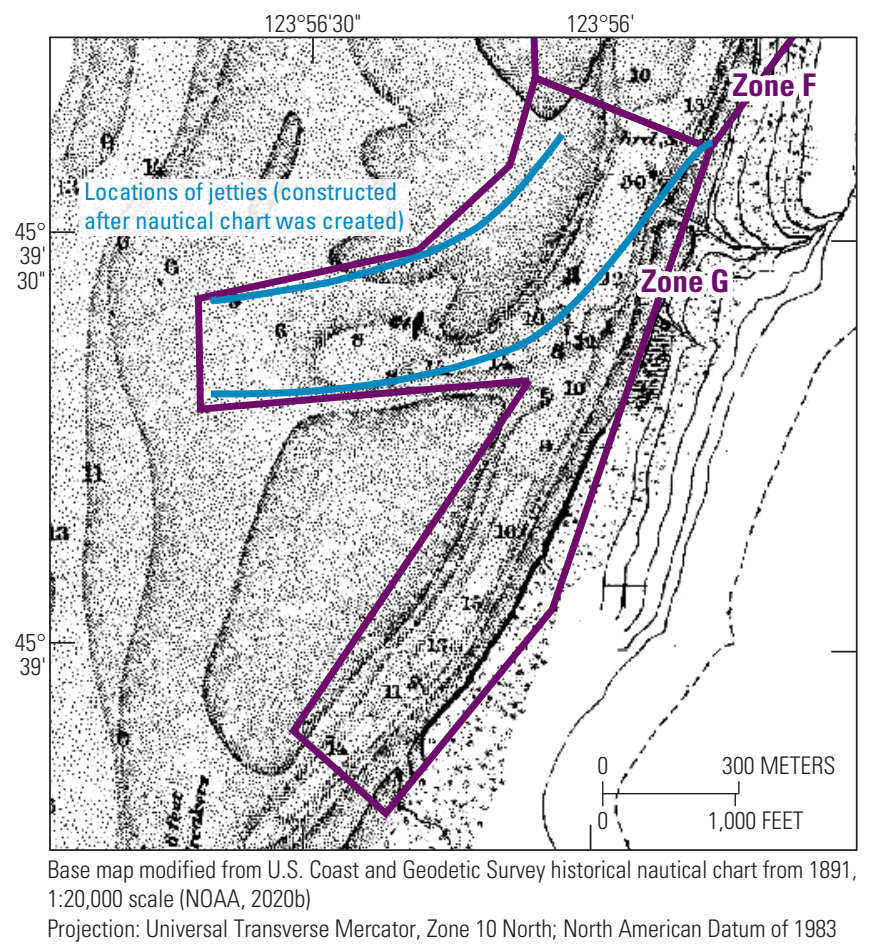

Figure 7. Nautical chart from 1891 for the Nehalem Bay, northwestern Oregon, at the entrance to the bay from the Pacific 0cean (zone G, river kilometer 1.2 to 0.0 ; nautical chart downloaded from National Oceanic and Atmospheric Administration, 2020b). 
Zone A extends from just upstream of the North Fork Nehalem River confluence (Rkm 13.6) to Rkm 11.3, downstream of Deer Island (locally named).

Zone B extends from zone A to Rkm 9.7, near the junction with Gallagher Slough.

Zone C extends along the main-stem Nehalem River from about Gallagher Slough (Rkm 9.7) past Wheeler to the downstream junction with the Lazarus Island Slough (Rkm 7.1).

Zone D encompasses the 1.2-k m-long side channel (Lazarus Island Slough) on the northwest side of Lazarus Island (approximately Rkm 9.6 to 7.2 along the main Nehalem River channel).

Zone $\mathrm{E}$ extends from the downstream end of the Lazarus Island Slough (Rkm 7.1) to Fishery Point and the Nehalem Bay State Park boat launch (Rkm 4.7).

Zone $F$ extends from Fishery Point to the upstream end of the Nehalem River jetties (Rkm 4.7 to 1.2).

Zone $\mathbf{G}$ encompasses the area along the jetties (Rkm 1.2 to 0 ), as well as an area of the historical Nehalem River mouth to the south present prior to the construction of the jetties in (completed in 1918; fig. 7).

Bathymetric changes were compared by evaluating the relative number of soundings within the seven zones of the Nehalem Bay. The horizontal distribution of depth value points varied among charts. For example, one chart may include more shallow depth values along channel margins whereas a subsequent chart may include more within the channel thalweg. Therefore, there is some uncertainty in comparing water depths among the charts that was not quantified for this study. Descriptive statistics and bin analyses of distribution of water depth values were deemed acceptable for evaluating multiple depth values within each of the seven broad zones. Depth values for each nautical chart were converted to meters and overlain with polygons of the zones in ArcGIS. All depth values within each zone were summarized with descriptive statistics and by $0.5-\mathrm{m}$ bins in Microsoft Excel (app. 1).

\section{Results of Bed Elevation and Bathymetric Change Analyses}

\section{Nehalem Bay Bed Elevations from Bathymetric Surveys, 1957 and 2019}

\section{Nehalem Bay, 1957}

The 1957 survey and DEM of the Nehalem Bay revealed bathymetric features between the confluence with the North Fork Nehalem and Nehalem Rivers (Rkm 13.6) and the mouth of the Nehalem River (Rkm 0; fig. 8A). The 1957 DEM also showed the elevations of the bed, width of the channel, and location of the channel thalweg throughout the surveyed area. Upstream of Rkm 9.8, the Nehalem Bay had a single, relatively narrow (about 100-300 m wide) channel, with bed elevations ranging from less than $-6.0 \mathrm{~m}$ (NAVD 88 ) near the confluence with the North Fork Nehalem River to greater than $0.5 \mathrm{~m}$ along the channel margins. Around Deer Island (Rkm 12.4-11.3) near the town of Nehalem, this area had a narrow side channel (about 50-m wide) with relatively high bed elevations $(-1.0-0.53 \mathrm{~m})$ and associated shallower water depths (fig. 8A). Between Rkm 9.8 and 9.1, the main channel split around Snag Island, a mid-channel island. Bed elevations were lower than $-4.6 \mathrm{~m}$ in the western (right facing downstream) channel along the bulkhead and dikes that partially disconnect Lazarus Island Slough from the main-stem Nehalem River, but exceeded $-2.2 \mathrm{~m}$ in the eastern channel (fig. $8 \mathrm{~A}$ ).

The 1957 survey showed the main-stem Nehalem River channel as a single channel from Rkm 9.2 past Wheeler until about Rkm 7.4 at the reconnection with Lazarus Island Slough (fig. 8A). The thalweg tended to flank the southern (left) side of the channel (with bed elevations as low as $-5.4 \mathrm{~m}$; fig. 9) until the channel widened after connecting with the downstream end of Lazarus Island Slough and mudflats (near Rkm 7.4). Between Rkm 7.4 and 3.0, the thalweg crossed toward the northwest edge (right) of the bay and followed the western bay along the Nehalem Bay State Park (opposite of Fishery Point). At approximately Rkm 3.0, the thalweg crossed the channel and followed the eastern (left) side of the channel to the mouth (Rkm 0). Downstream of about Rkm 1.4, channel width decreased to about $220-300 \mathrm{~m}$ and bed elevations tended to decrease; some of the lowest elevations (less than $-10 \mathrm{~m}$ ) within the Nehalem Bay were observed in this segment (fig. 8A). Beyond the study area (westward past Rkm 0 and beyond the jetties), a fan was present at the mouth of the Nehalem River with bed elevations generally increasing toward the Pacific Ocean. 


\section{A. 1957 digital elevation model}

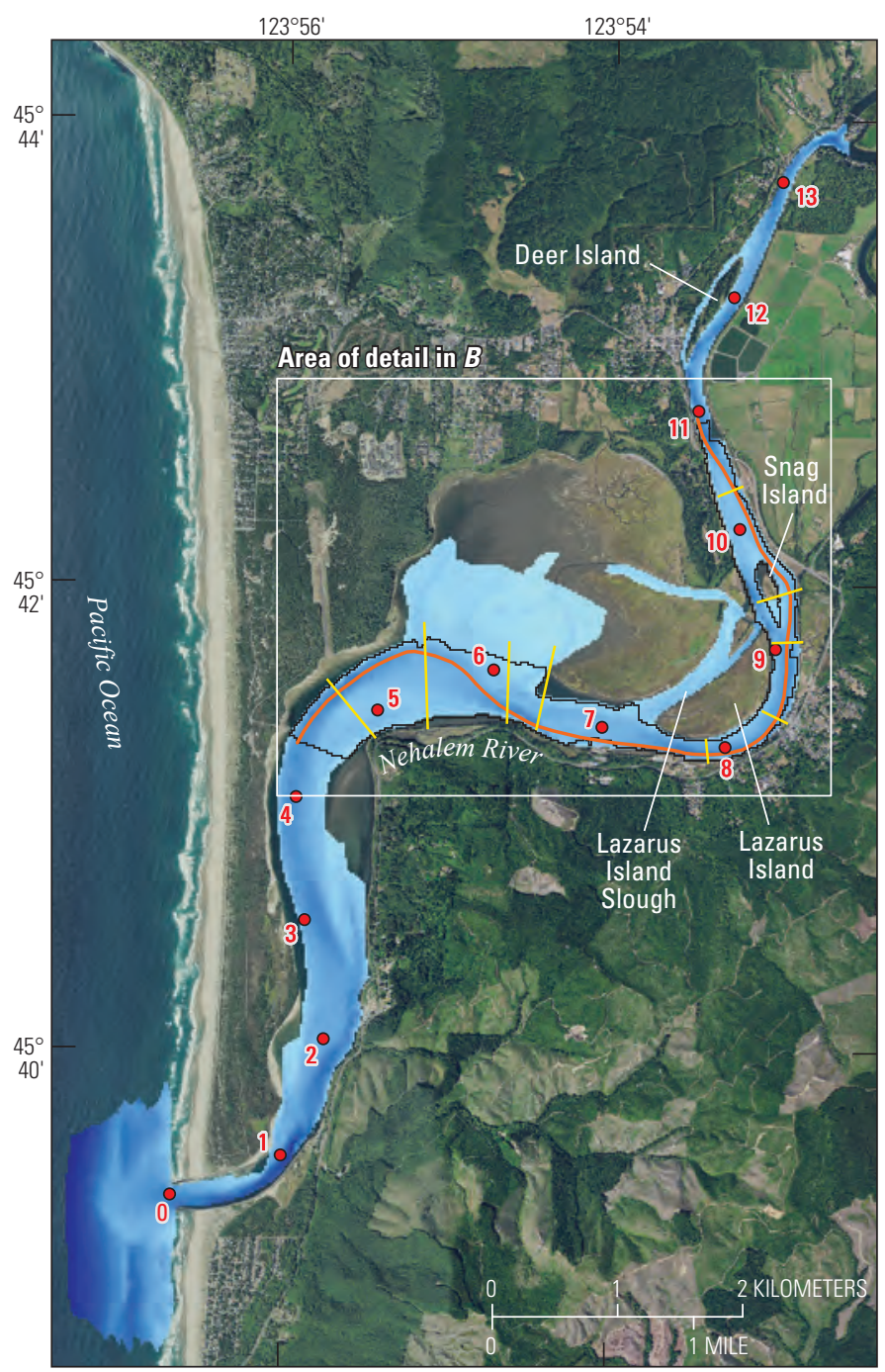

\section{B. 2019 digital elevation model}

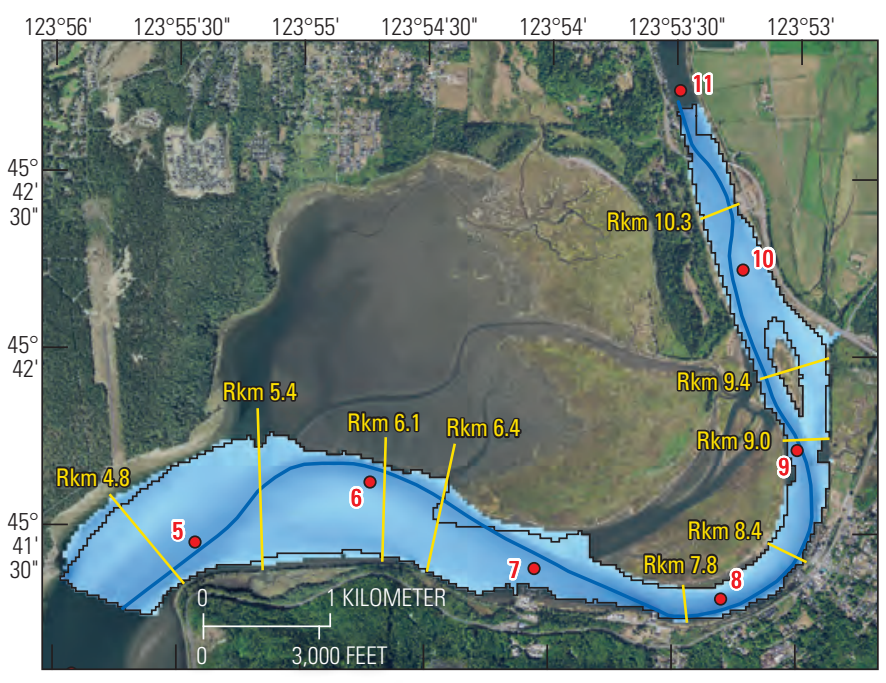

Base maps modified from 2018 Oregon Statewide Imagery Program data, 0.3-meter resolution. Projection: Universal Transverse Mercator, Zone 10 North; North American Datum of 1983

Digital elevation models (20-meter resolution) modified from U.S. Coast and Geodetic Survey (1958a, b) and U.S. Geological Survey (Gordon and others, 2020 a, b) bathymetric surveys, various resolutions.

\section{EXPLANATION}

Bed elevation, in meters above North American Vertical Datum of 1988

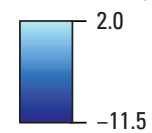

$-11.5$

Area of suvey overlap

1957 thalweg

2019 thalweg

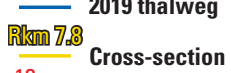

13 River kilometer

Figure 8. Digital elevation models constructed from bathymetric survey data acquired in $1957(A)$ and $2019(B)$ within the Nehalem Bay, northwestern Oregon, including the outline of a polygon in which the surveys overlap.

Within the sloughs, side channels, and mudflats to the north and west of the main-stem Nehalem River channel between Rkm 9.6 (near Dean Point, fig. 2) and Rkm 5.4, elevations were typically high compared with other segments of the main channel, with most of that area lying above $0 \mathrm{~m}$; exceptions were the main channel of Lazarus Island Slough and some tidal channels within the mudflats that had elevations less than $0 \mathrm{~m}$ (fig. 8A).

\section{Nehalem Bay, 2019}

The 2019 survey extended along the channel of the Nehalem River from Rkm 10.8 (upstream of the Highway 101 Bridge) to about Rkm 4.4 (near Fishery Point; fig. 8B). As in the survey from 1957, the Nehalem River upstream of Rkm 9.8 had a single, relatively narrow (100-300 m) channel (fig. $8 B$ ) with bed elevations lower than $-6.5 \mathrm{~m}$ near Wheeler (minimum $-6.9 \mathrm{~m}$ at $\mathrm{Rkm}$ 7.7) and as high as $1.4 \mathrm{~m}$ near the entrance to Gallagher Slough. Between Rkms 9.6 and 9.0, the channel split around Snag Island; bed elevations suggest this feature extended from about Rkm 10.0 to 9.0. The channel along the western (right) side of the island had relatively lower bed elevations (in the -1 to -3 -m-range) compared to the higher elevations (typically greater than $-1.5 \mathrm{~m}$ ) in the eastern (left) channel, which was connected to a small area of mudflats and Gallagher Slough (east of Rkm 9.4; fig. 8B). The main channel along Lazarus Island was lowest (fig. 9) to the south (left) along the town of Wheeler, with the lowest points (less than $-5.9 \mathrm{~m}$ ) along the thalweg near Rkm 7.6; higher elevations were present along Lazarus Island (fig. 8B). From Lazarus Island, the channel thalweg crossed northward and followed the right side of the channel near the large area of mudflats until about Rkm 5.6, where the thalweg migrated toward the south and east (left) side of the channel at Fishery Point (Rkm 4.4). 

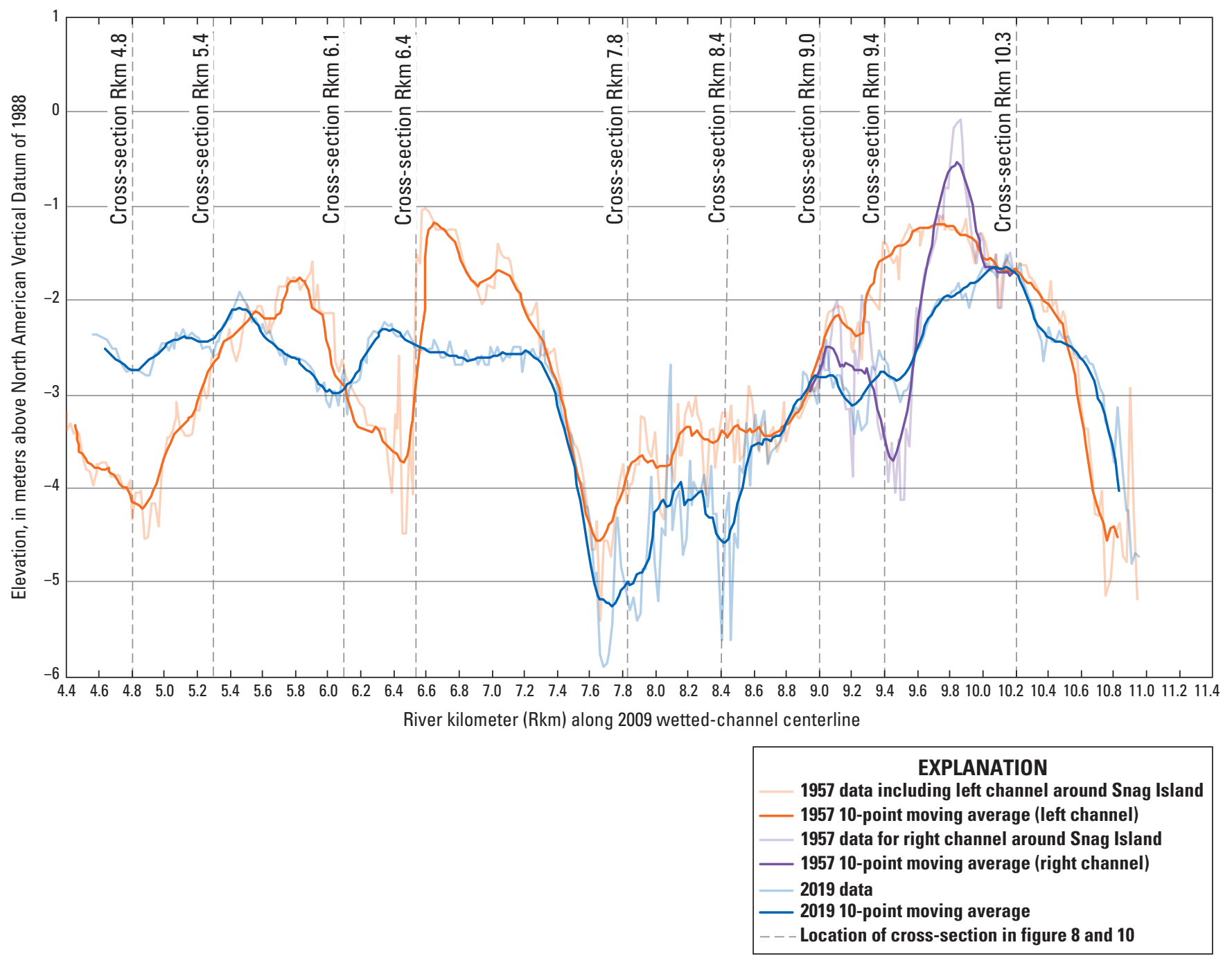

Figure 9. Longitudinal thalweg profiles from 1957 and 2019 where surveys overlap along the river reach from river kilometer 10.8 to 4.4 of the Nehalem Bay, northwestern Oregon. Bed elevations were extracted from digital elevation models for the respective surveys and aligned with the closest river kilometer along the 2009 wetted channel centerline (Jones and others, 2012).

\section{Bed-Elevation Changes from Surveys of 1957 and 2019, Rkm 10.8 to 4.4}

\section{Overall Patterns of Bed-Elevation Change}

Comparison of the bathymetric data from the surveys of 1957 and 2019 indicates that the area of the Nehalem Bay with overlapping survey coverage (Rkm 10.8 to 4.4 ) changed considerably between the two surveys. The most substantial change is the migration of the thalweg downstream of Lazarus Island to downstream of Fishery Point (Rkm 7.4 to 4.4; fig. 8). From about Rkm 7.4 to 5.6, the thalweg migrated from the left side of the channel in 1957 to the right side of the channel in 2019. From Rkm 5.6 to 4.4, the thalweg migrated from the right side of the channel in 1957 to the left side of the channel in 2019. Changes in bed elevations along the thalwegs from
1957 to 2019 were variable, but in general the segment from Rkm 10.6 to 6.6 was lower in 2019 (fig. 9). Through the area of survey overlap, the thalweg shortened from about 7.0 to 6.7 kilometers over that same period (fig. 8). Both increases and decreases in bed elevation were observed at most cross sections (fig. 10C, $D, E, F, G, v$ ), though at some locations erosion (fig. 10A), deposition (fig. 10B), or marginal changes (fig. $10 H$ ) were evident in the cross sections. Comparisons of the two surveys account only for net changes over the entire analysis period and do not account for changes that may have occurred over smaller timeframes. Rapid erosion or deposition of sediment during floods, as well as repeated erosion and deposition, that may have occurred multiple times over the 62 -year period between the surveys are not documented in the assessment. 


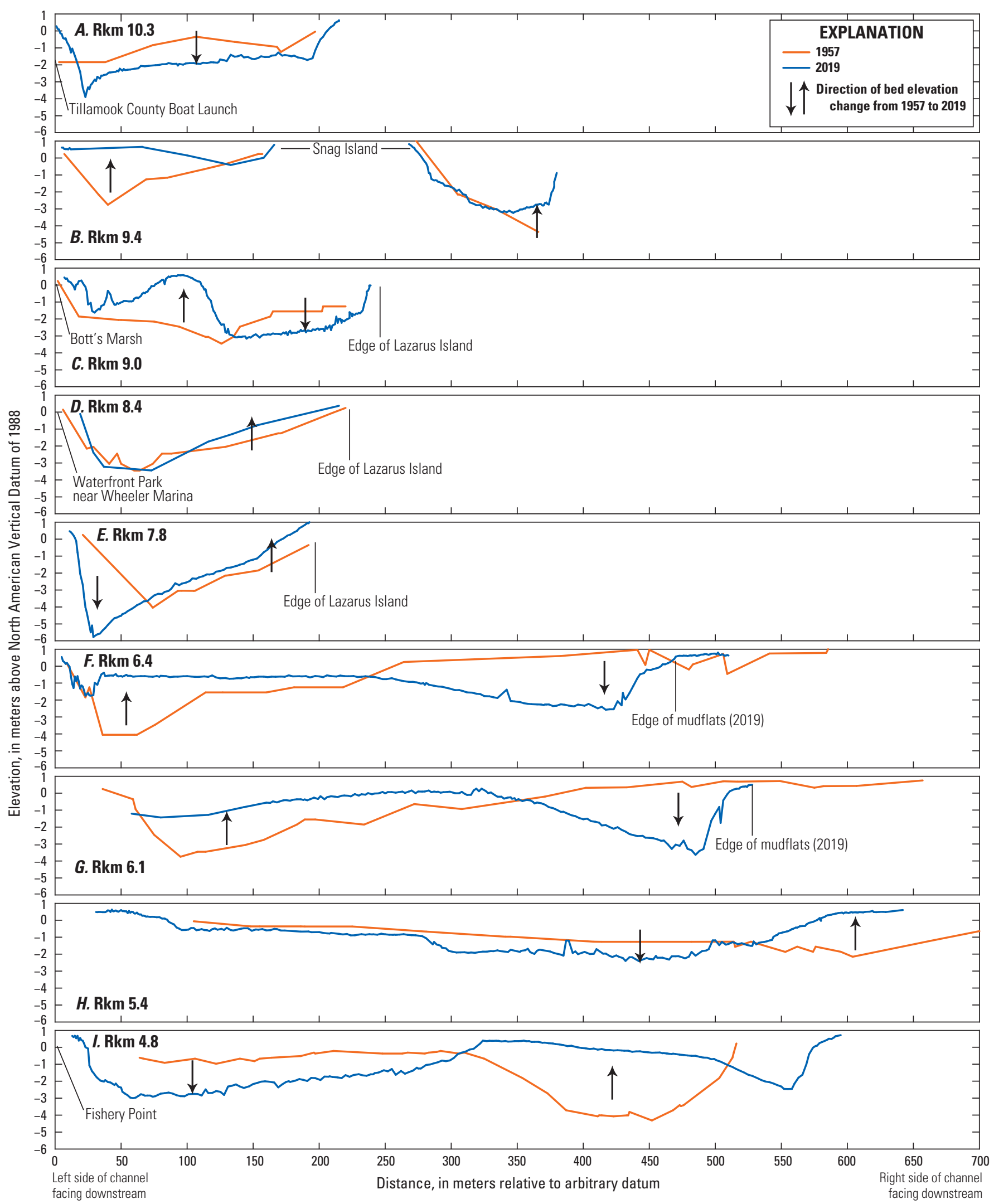

Figure 10. Survey cross sections from 1957 and 2019 along the Nehalem Bay, northwestern Oregon at selected river kilometer locations. Horizontal datum arbitrary; vertical datum relative to North American Vertical Datum of 1988. 


\section{Longitudinal Bed-Elevation Differences in the Thalweg}

Differences in bed elevations along the thalwegs in 1957 and 2019 vary longitudinally (fig. 9). Because the location of the thalweg changed from 1957 to 2019 , bed elevations along the thalwegs cannot be compared directly to identify specific locations of sediment erosion or deposition. Instead, the bed elevations of the thalwegs can be compared to examine how the deepest part of the channel moved longitudinally from Rkm 10.8 to 4.4. Compared to 1957 , bed elevations along the 2019 thalweg were: (1) higher in some locations by as much as $1.6 \mathrm{~m}$ and lower in other locations by about $2.0 \mathrm{~m}$ between Rkm 10.8 and 8.6, (2) generally lower by approximately $0.3-1.3 \mathrm{~m}$ between $\mathrm{Rkm} 8.6$ and 6.6, (3) higher by approximately $0.1-1.7 \mathrm{~m}$ between $\mathrm{Rkm} 6.6$ and $6.1,(4)$ lower by approximately $0.2-0.9 \mathrm{~m}$ between $\mathrm{Rkm} 6.1$ and 5.5, and (5) higher by approximately $0.6-1.5 \mathrm{~m}$ between $\mathrm{Rkm} 5.5$ and 4.4 (fig. 9). Regardless of these changes, most of the thalweg bed elevations were $-1.0 \mathrm{~m}$ or lower in both surveys.

\section{Bed-Elevation Changes at Selected Cross Sections}

Channel cross sections are also useful for comparing changes in bed elevation and thalweg locations between the two sets of survey data (fig. 10). Although the bed-elevation points for channel cross sections were pulled directly from survey data and they do not overlap completely, comparison of the cross sections is helpful for identifying sediment deposition and erosion. Bed elevation values were extracted from the 1957 and 2019 surveys; locations where the elevations in the 2019 channel were higher than those in the 1957 channel indicate sediment deposition, and locations where the 2019 channel is lower than those in the 1957 channel indicate sediment erosion. Bed-elevation cross sections at 9 locations where the 1957 and 2019 surveys overlap are summarized here.

- At cross-section Rkm 10.3 (figs. 8 and 10A), the surveys span a single channel near the Tillamook County Boat Launch. Comparison of the 2019 and 1957 surveys shows bed lowering and erosion across most of the channel, with deepening by as much as 2 $\mathrm{m}$ at one location. At the left side of the channel near the boat launch and left bank, however, the profile shows as much as $2 \mathrm{~m}$ of deposition.

- Cross-section Rkm 9.4 (figs. 8 and 10B) spans the two main channels that flow around Snag Island. Changes from 1957 to 2019 show sediment deposition is predominant in both channels, with increases in bed elevation exceeding $3.4 \mathrm{~m}$ in the left channel.
- At cross-section Rkm 9.0 (figs. 8 and 10C), near the downstream end of Snag Island and adjacent to Bott's Marsh and Lazarus Island, the main Nehalem River converges back into a single channel. Both surveys cover a 230-m segment. Deposition occurred in more than half of the cross section (including the entire left side of the channel), with maximum deposition of more than $3.3 \mathrm{~m}$ near the middle of the cross section (or just downstream of Snag Island). The overall pattern of deposition along the left side of the channel and erosion along the right side of the channel coincide with thalweg location changes observed from DEMs (fig. 8), indicating migration of the channel thalweg toward Lazarus Island.

- Cross-section Rkm 8.4 (figs. 8 and 10D) near Wheeler (adjacent to Waterfront Park and Lazarus Island) shows local bed lowering in the thalweg mid-cross section. Deposition along the channel margins is minimal (typically less than a $1 \mathrm{~m}$ ) relative to the deposition in the cross sections at Rkm 9.4 and 9.0 (more than $3 \mathrm{~m}$ ).

- Cross-section Rkm 7.8 (fig. 8 and 10E) near the downstream end of Wheeler shows more substantial deepening than at Rkm 8.4. Survey data show the thalweg elevation decreased from $-4.0 \mathrm{~m}$ in 1957 to about $-5.8 \mathrm{~m}$ in 2019 . Also, the location of the thalweg migrated towards the left side of the channel (where total vertical erosion at the location exceeded $5.0 \mathrm{~m}$ ). As the left side of the channel deepened, minor increases occurred in bed elevation along the right side (up to $0.7 \mathrm{~m}$ ).

- Cross-section Rkm 6.4 (figs. 8 and 10F) is just downstream of West Island, near the large area of mudflats where the channel is twice as wide as at upstream cross sections. Bed elevations along the left side of the channel, where the thalweg was present in 1957 , increased by as much as $3.6 \mathrm{~m}$, whereas elevations near the right side of the channel decreased by as much as $3.4 \mathrm{~m}$. These changes in bed elevations appear to be related to the thalweg migrating 380 $\mathrm{m}$ toward the right side of channel in the 62 years between surveys.

- Cross-section Rkm 6.1 (figs. 8 and 10G) also spans the Nehalem River channel near the area of large mudflats and exhibits a similar pattern of thalweg migration towards the right bank as at $\mathrm{Rkm}$ 6.4, resulting in erosion along the right side and deposition along the left side of the channel. Increases and decreases in bed elevation resulted in deposition of $2.4 \mathrm{~m}$ and erosion of $4.0 \mathrm{~m}$ that appear to correspond with thalweg migration. 
Table 6. Bathymetric changes between 1957 and 2019 within the Nehalem Bay, northwestern Oregon, river kilometer 10.8 to river kilometer 4.4, including net, erosional, and depositional changes for the area analyzed.

[Metrics comparing digital elevation models between 1957 and 2019 were generated using Geomorphic Change Detection software (GCD 7.4.4.0; Riverscapes Consortium, 2019). Abbreviation: \pm , plus or minus]

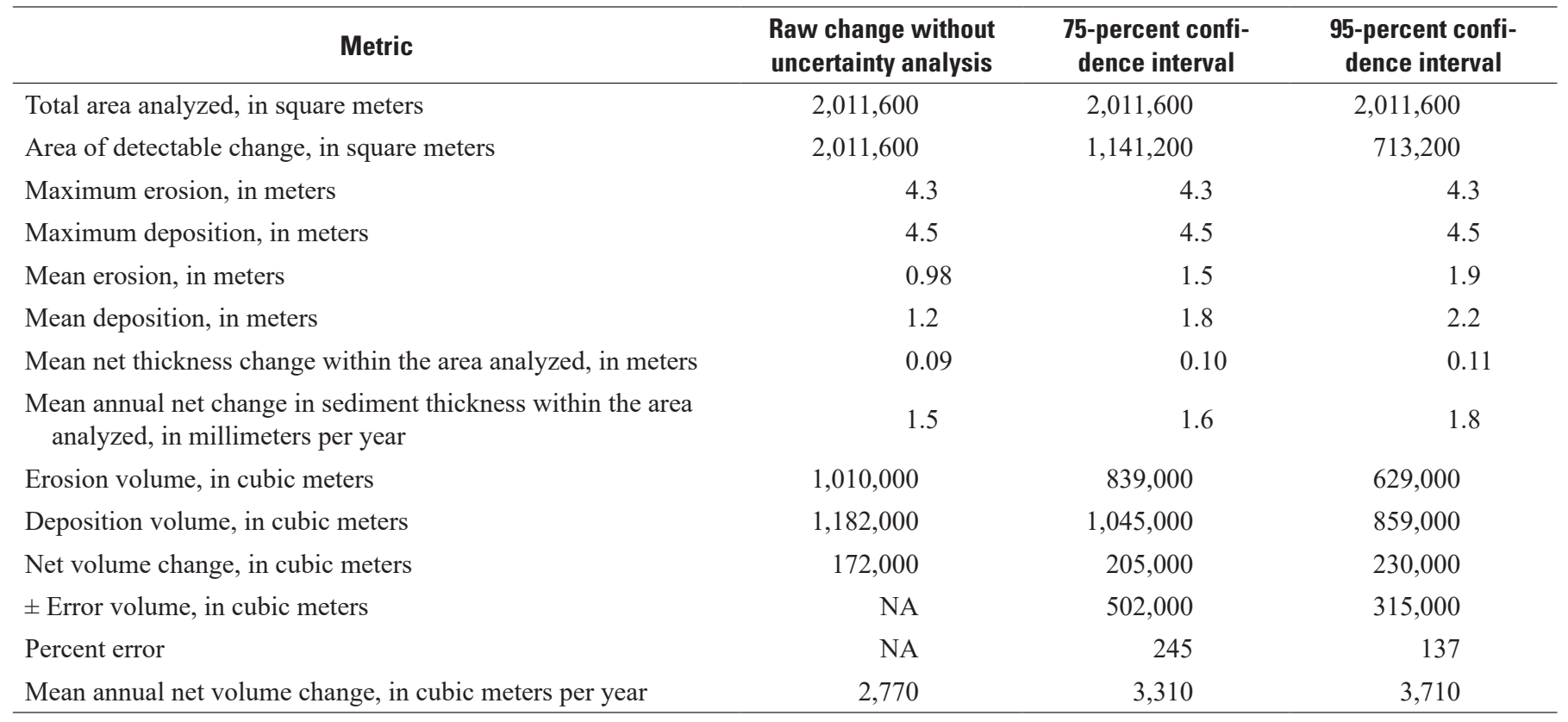

- Cross-section Rkm 5.4 (figs. 8 and 10H) spans the main-stem Nehalem River just downstream of where the 1957 and 2019 thalwegs intersect (Rkm 5.6). Unlike the upstream cross sections at Rkm 6.4 and 6.1 , more bed lowering is observed along the left portion of the channel (up to about $1.1 \mathrm{~m}$ ) and deposition is observed along the right portion of the channel (up to about $2.6 \mathrm{~m}$ ), reflecting changes in the thalweg location. Unlike changes seen at Rkm 6.4, here thalweg migration did not correspond with large changes in thalweg elevation, as thalweg elevation remained similar for both surveys (-2.2 $\mathrm{m}$ in 1957 and $-2.4 \mathrm{~m}$ in 2019).

- Cross-section Rkm 4.8 (figs. 8 and 10I) crosses the Nehalem Bay from Fishery Point to Nehalem Bay State Park (upstream of the boat launch). Like the cross section at Rkm 5.4, erosion of the channel bed and deposition are predominant in the left and right sides of the channel, respectively. However, the magnitude of changes at this cross section were greater than at other cross sections. Maximum changes in bed elevation correspond with thalweg location; elevations have decreased by as much as $2.4 \mathrm{~m}$ along the left portion of the channel and have increased by more than $4.0 \mathrm{~m}$ along the right portion.

\section{Erosion and Deposition from Digital Elevation Models of Difference}

DEMs of difference from the 1957 and 2019 bathymetric surveys illustrate locations of erosion and deposition within the overlapping surveyed area and provide estimates of the volume change over the period. Maximum erosion (or water deepening) reached up to $4.3 \mathrm{~m}$ near Rkm 7.8 (point $A$ on fig. 11A) and up to $4.5 \mathrm{~m}$ of deposition near Rkm 5.0 (point $B$ on fig. 11A) with a mean change in thickness of $0.10 \mathrm{~m}$. For the channel reach between Rkm 10.8 and 4.4, we calculated $1,010,000$ and $1,182,000 \mathrm{~m}^{3}$ of raw change in erosion and deposition, respectively (table 6; figs. 11 and 12), resulting in a net raw deposition of $172,000 \mathrm{~m}^{3}$ and an annual mean net deposition rate of about $2,770 \mathrm{~m}^{3} /$ year over the 62 -year analysis period (table 6). The net volume value is the difference between the values for erosion and deposition, and the associated error is of a similar in magnitude. 

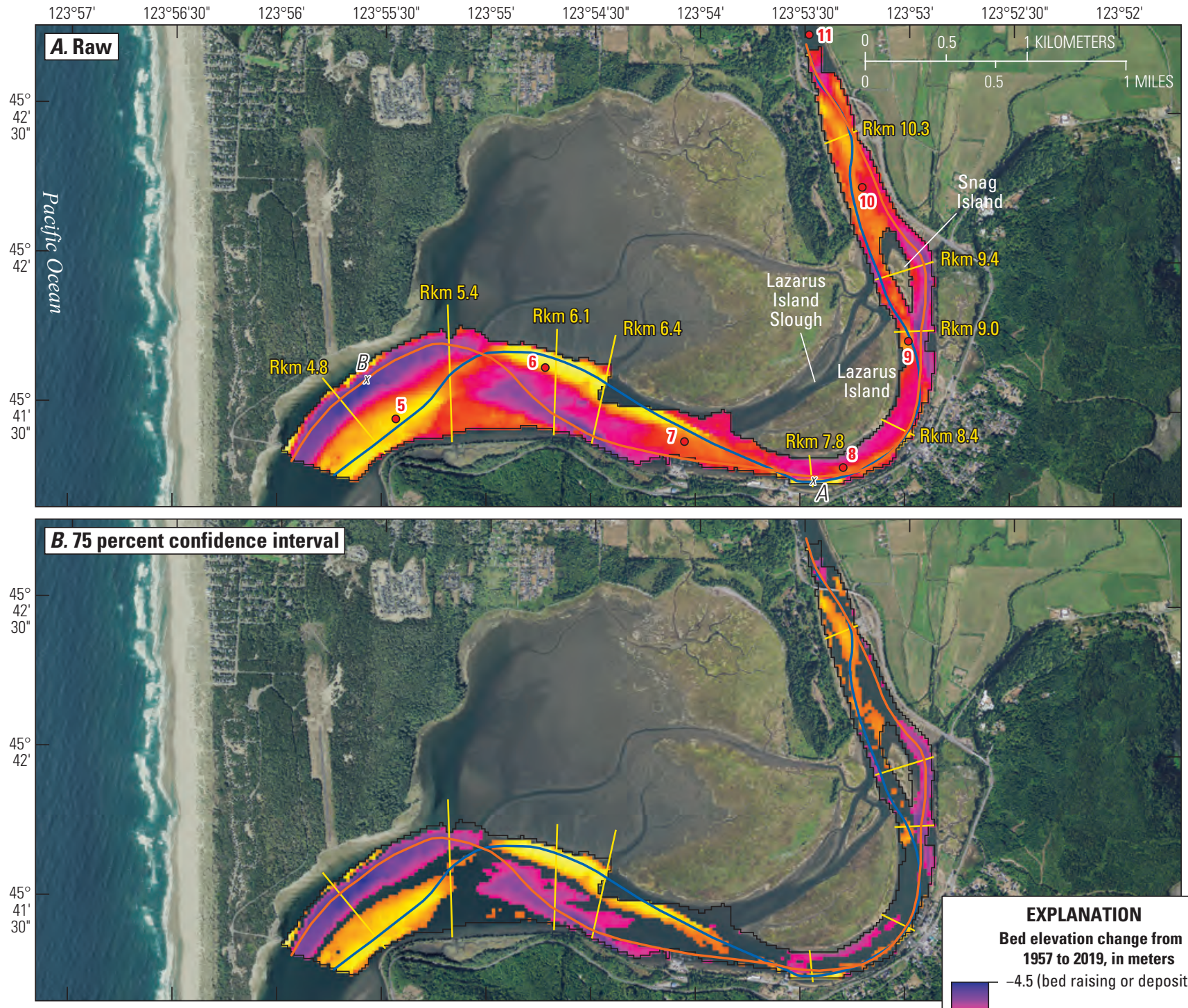

Bed elevation change from 1957 to 2019, in meters

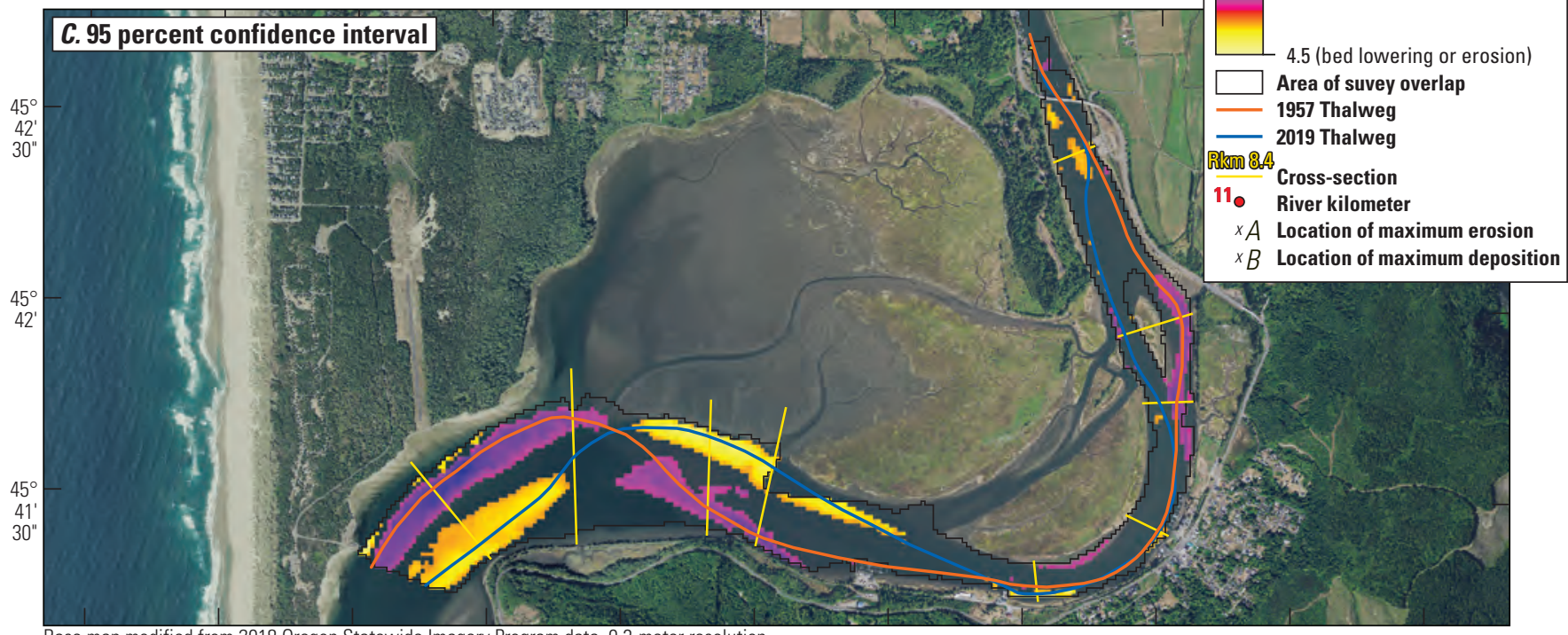

Base map modified from 2018 Oregon Statewide Imagery Program data, 0.3-meter resolution.

Projection: Universal Transverse Mercator, Zone 10 North; North American Datum of 1983

Figure 11. Bed-elevation changes derived from bathymetric surveys acquired in 1957 and 2019 within the Nehalem Bay, northwestern Oregon, river kilometer 10.8-4.4 for raw $(A)$ and probabilistic threshold change ( $B, 75$ percent confidence interval; $C, 95$ percent confidence interval) analyses. 


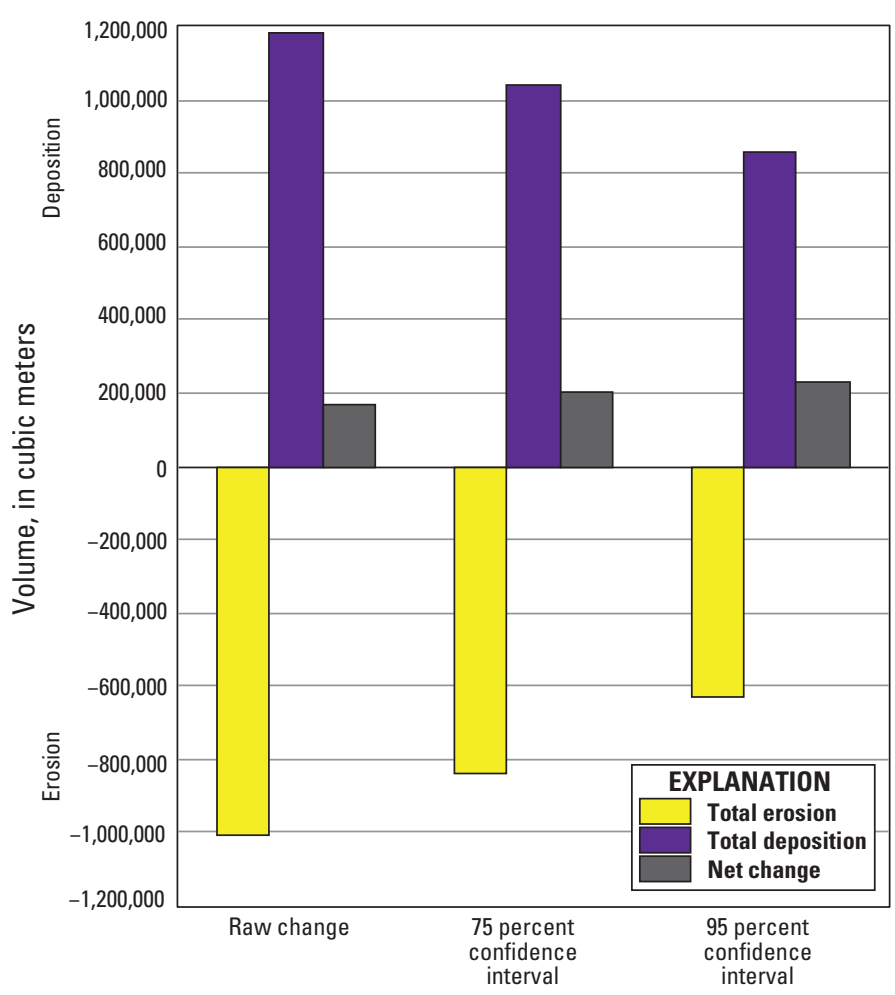

Figure 12. Calculated volumetric (erosion, deposition, and net) change between river kilometers 10.8 and 4.4 for surveys acquired in 1957 and 2019 for the Nehalem Bay, northwestern Oregon.

By applying probabilistic thresholds to the analyses, the overall area of detectable change and mean depth of erosion decreased, whereas the net change in volume increased (table 6; figs. 11B,C and 12). The 75 percent confidence interval change analysis was able to detect change for 57 percent of the analysis area, compared to 35 percent for the more conservative 95 percent confidence change analysis. The erosion, deposition, and net change volumes at the 75 percent confidence interval are $839,000,1,045,000$, and 205,000 $\mathrm{m}^{3}$ $\left( \pm 502,000 \mathrm{~m}^{3}\right.$ - the net volume error associated with uncertainties in the survey data, datum conversions, and DEM interpolation), respectively. Further increasing the confidence interval to 95 percent suggests less overall erosion and deposition (629,000 and $859,000 \mathrm{~m}^{3}$, respectively) but greater net deposition $\left(230,000 \mathrm{~m}^{3} \pm 315,000 \mathrm{~m}^{3}\right)$. The mean net change in sediment thickness at both the 75 and 95 percent confidence intervals was 0.10 and $0.11 \mathrm{~m}$, respectively. Over the 62-year period, the mean annual rate of sediment thickness change was about $1.6-1.8 \mathrm{~mm} /$ year across the area analyzed. At the 95 percent confidence interval, several locations of calculated erosion and deposition are still detectable and are summarized here.

- Erosion and deposition in some small areas (less than $10,000 \mathrm{~m}^{2}$ ) near the Highway 101 bridge and Tillamook County Boat Launch (Rkm 10.8-10.2),
- Deposition in the channels around Snag Island (Rkm 9.6-8.8) with predominant changes occurring in the left channel past Gallagher Slough and more subtle changes along the head of the Lazarus Island Slough,

- Erosion along part of the thalweg near Wheeler and deposition along the opposite side of the channel adjacent to Lazarus Island ( $\mathrm{Rkm}$ 8.4-7.6),

- Large areas of erosion and deposition coinciding with thalweg migration at $\mathrm{Rkm} 7.1$ and 5.6, where deposition of more than $88,000 \mathrm{~m}^{2}$ coincides with the position of the 1957 thalweg and erosion of more than $98,000 \mathrm{~m}^{2}$ coincides with the position of the 2019 thalweg, and

- Large areas of erosion and deposition coinciding with thalweg migration at $\mathrm{Rkm} 5.6$ and 4.4, where deposition of more than $170,000 \mathrm{~m}^{2}$ coincides with the position of the 1957 thalweg and erosion of more than $135,000 \mathrm{~m}^{2}$ coincides with the position of the 2019 thalweg. Erosion also was observed along a portion of the right channel margin near the Nehalem Bay State Park between Rkm 5.2 and 4.4.

\section{Distribution of Water Depth Values from Nautical Charts, 1891-2004}

Evaluation of water depths depicted on five nautical chart publications spanning the years 1891 to 2004 and covering portions of the Nehalem Bay show that the range of water depths vary with publication year and location (table 7; fig. 13; app. 1). Across all years and seven analysis zones, water depths ranged from about 0.2 to $9.4 \mathrm{~m}$. Zone $\mathrm{G}$ at the mouth of the Nehalem River consistently had the greatest water depths for each period (7.9-9.4 m) and also displayed the greatest range in depths (7.3-8.8 m). By contrast, zone $\mathrm{D}$, encompassing Lazarus Island Slough, had the smallest range in water depths (1.1-2.4 m).

Median water depths represent the middle value of all measured depths plotted within a zone and are useful for characterizing how relatively deep or shallow the zone is without skewing towards a few high (deep) or low (shallow) depth values. Median water depths ranged from about 0.3 to $6.4 \mathrm{~m}$ across all years and zones (table 7; fig. 13; app. 1). For zones for which two or more nautical charts depicting updated water depths were available, comparison of consecutive charts shows that all zones had decreasing median water depths during at least one period. Zones C, D, F, and G also showed increasing median water depths during at least one period (table 7). However, water depths did not systematically increase or decrease throughout all zones during the same periods. For example, between 1947 and 1970, the median water depth increased in zone $\mathrm{C}$ while they decreased in zone D. The distributions of water depths determined from nautical charts within each zone of the Nehalem Bay are described below. 


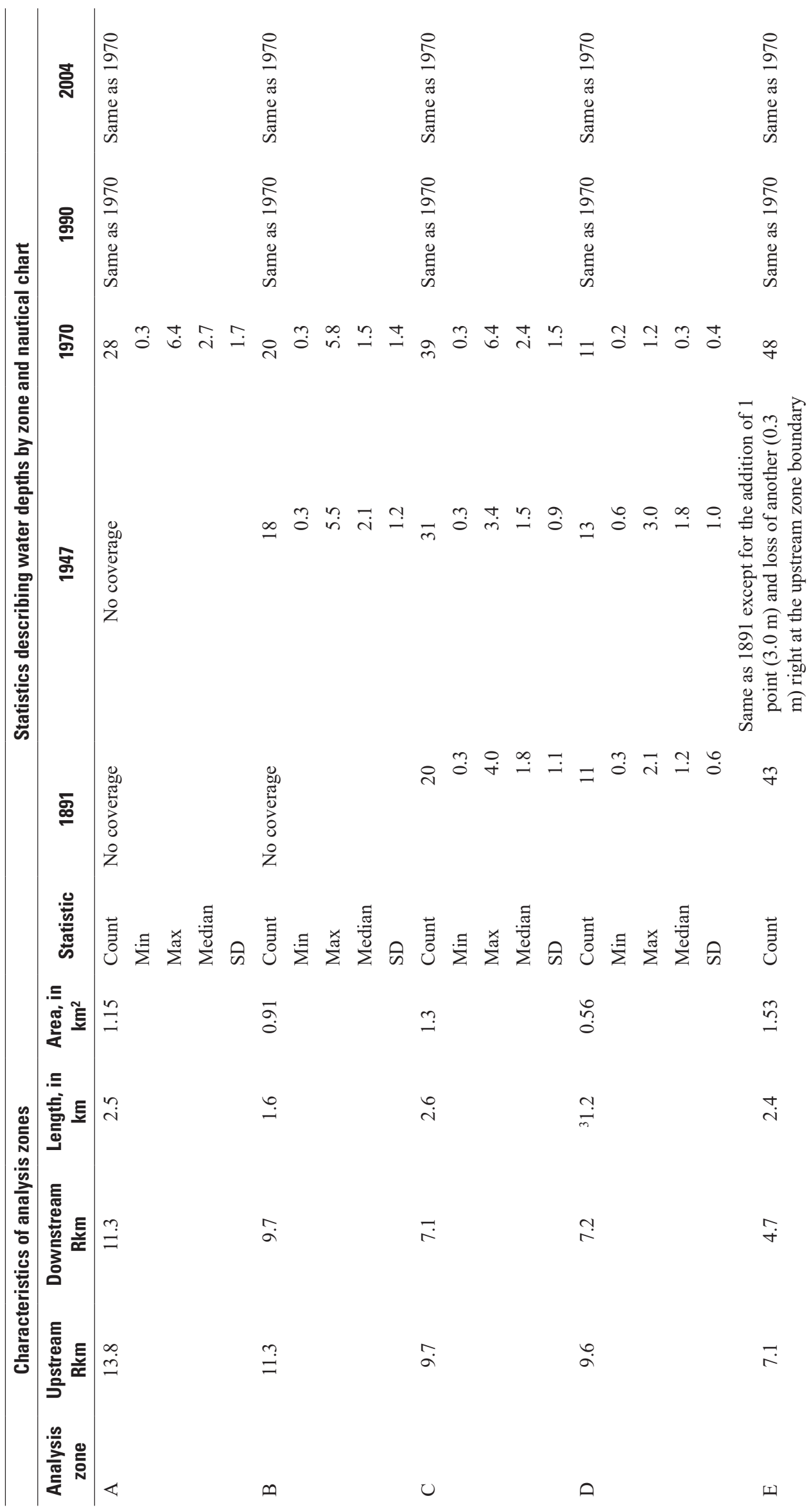




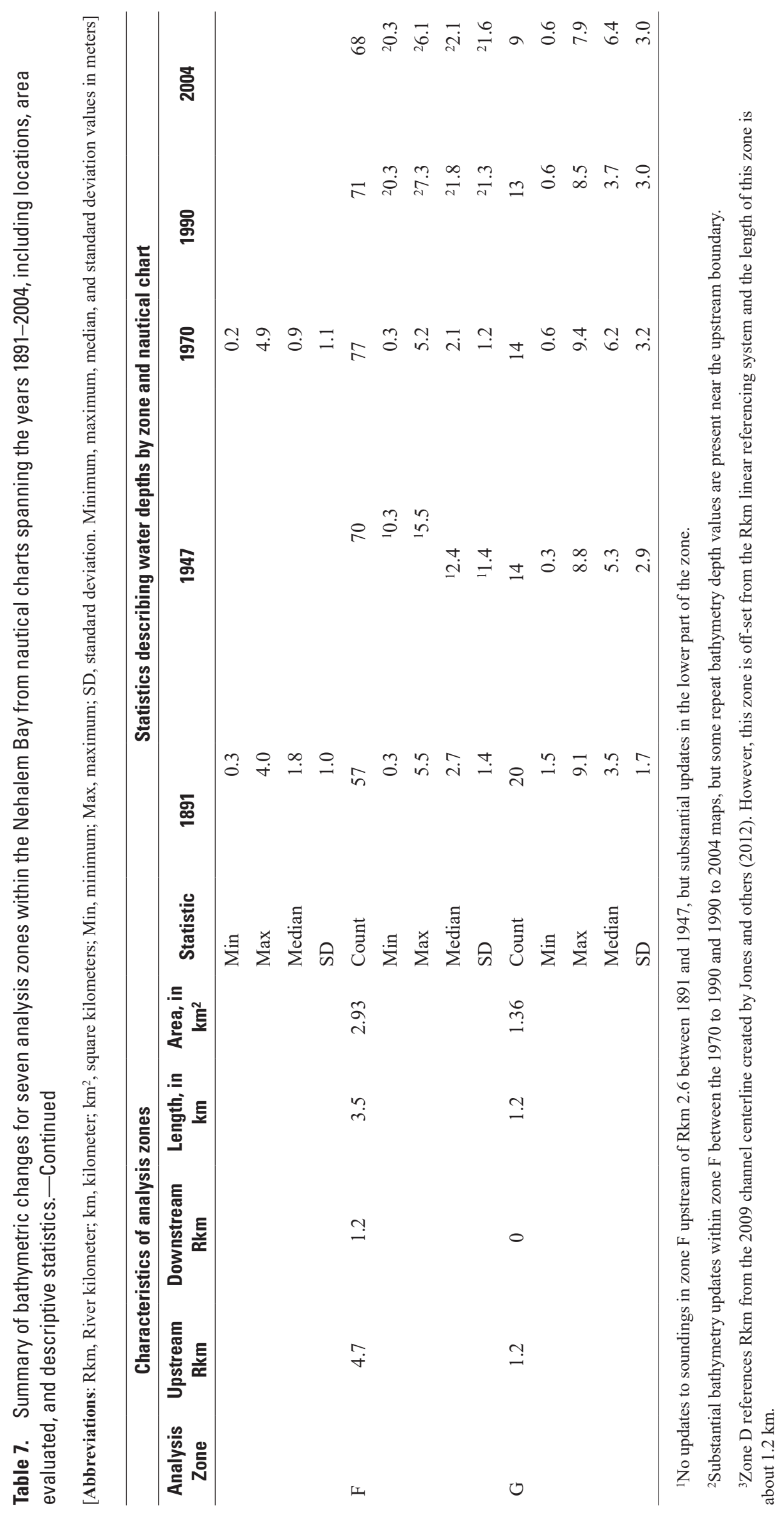



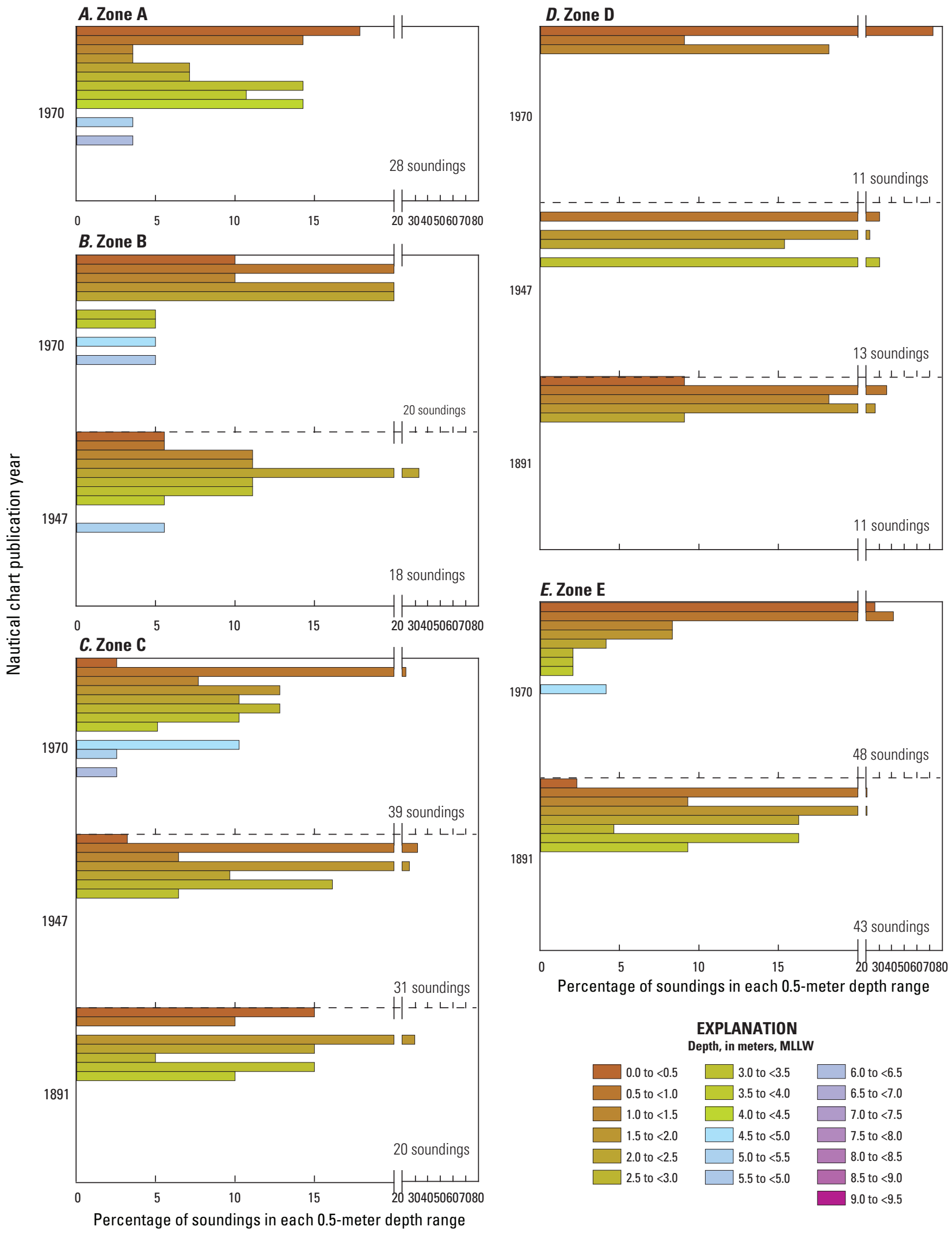

Figure 13. Histograms of water depths (plotted in 0.5-m depth increments) from U.S. Coast and Geodetic Survey nautical charts for $1891,1947,1970,1982$, and 2004, spanning zones $A, B, C, D, E, F$, and $G$, within the Nehalem Bay, northwestern Oregon. MLLW, mean lower low water. 

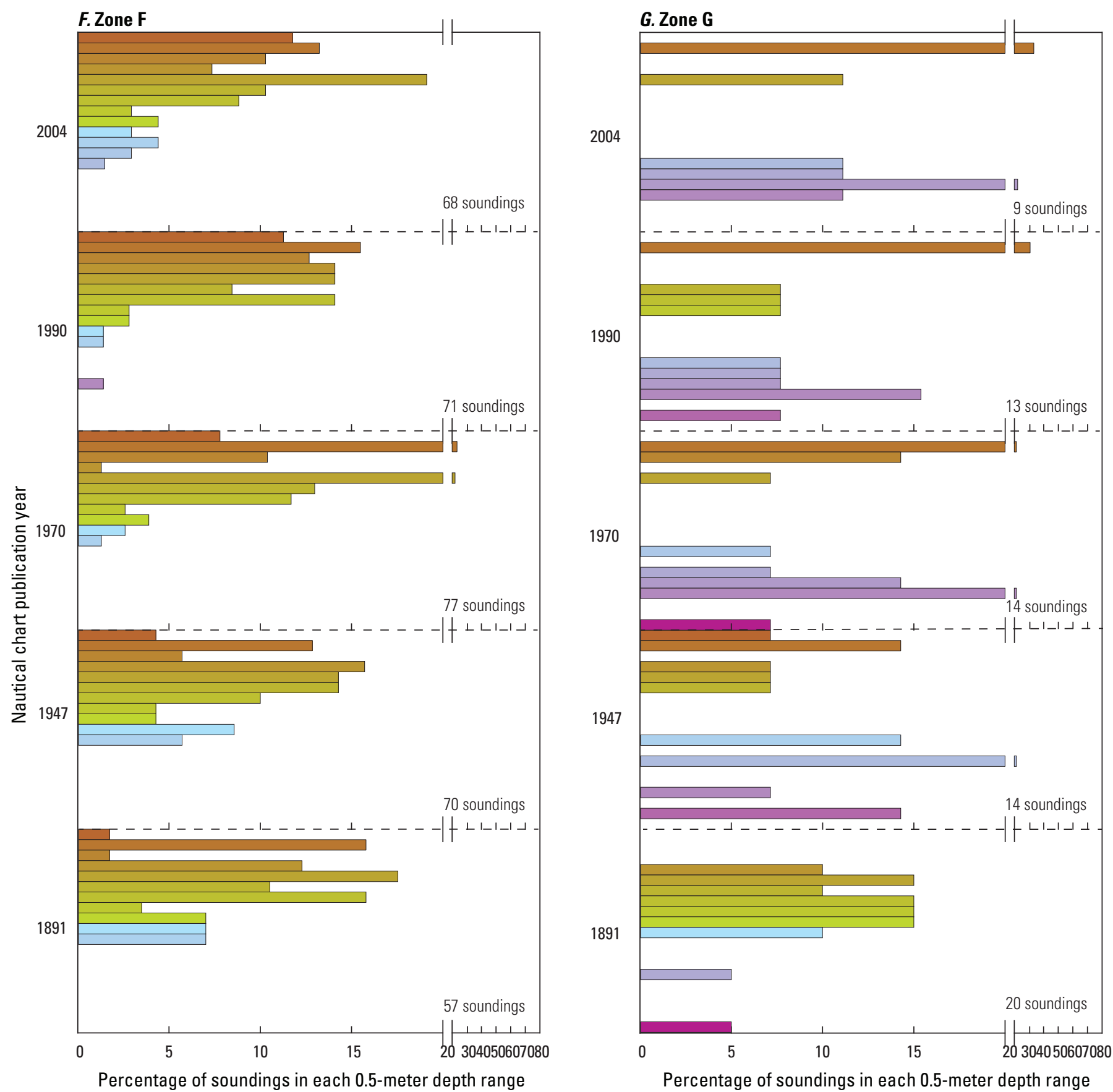

EXPLANATION

Depth, in meters, MLLW

\begin{tabular}{|c|c|c|}
\hline 0.0 to $<0.5$ & 3.0 to $<3.5$ & 6.0 to $<6.5$ \\
\hline 0.5 to $<1.0$ & 3.5 to $<4.0$ & 6.5 to $<7.0$ \\
\hline 1.0 to $<1.5$ & 4.0 to $<4.5$ & 7.0 to $<7.5$ \\
\hline 1.5 to $<2.0$ & 4.5 to $<5.0$ & 7.5 to $<8.0$ \\
\hline 2.0 to $<2.5$ & 5.0 to $<5.5$ & 8.0 to $<8.5$ \\
\hline 2.5 to $<3.0$ & 5.5 to $<5.0$ & 8.5 to $<9.0$ \\
\hline & & 9.0 to $<9.5$ \\
\hline
\end{tabular}

Figure 13.-Continued 


\section{Zone A}

The only nautical chart that contained bathymetric data within zone A was published in 1970. Most water depths depicted on the chart in this zone (number of points $[\mathrm{n}]=28$ ) are relatively shallow (table 7; figs. $13 A$ and 14; app. 1). Thirty-two percent of the points are less than $1 \mathrm{~m}$ deep. Most of the shallow depth values are in the side channel around Deer Island or along the channel margins. Two relatively deep depth values were also plotted - one at $5.5 \mathrm{~m}$ near Rkm 12.9 and one at $6.4 \mathrm{~m}$ near the confluence of the North Fork Nehalem and main-stem Nehalem Rivers. The remaining depth values ( $\mathrm{n}=17$ or 61 percent) were distributed between 1 and $5 \mathrm{~m}$ depths and taken along the mid-channel area throughout zone A.

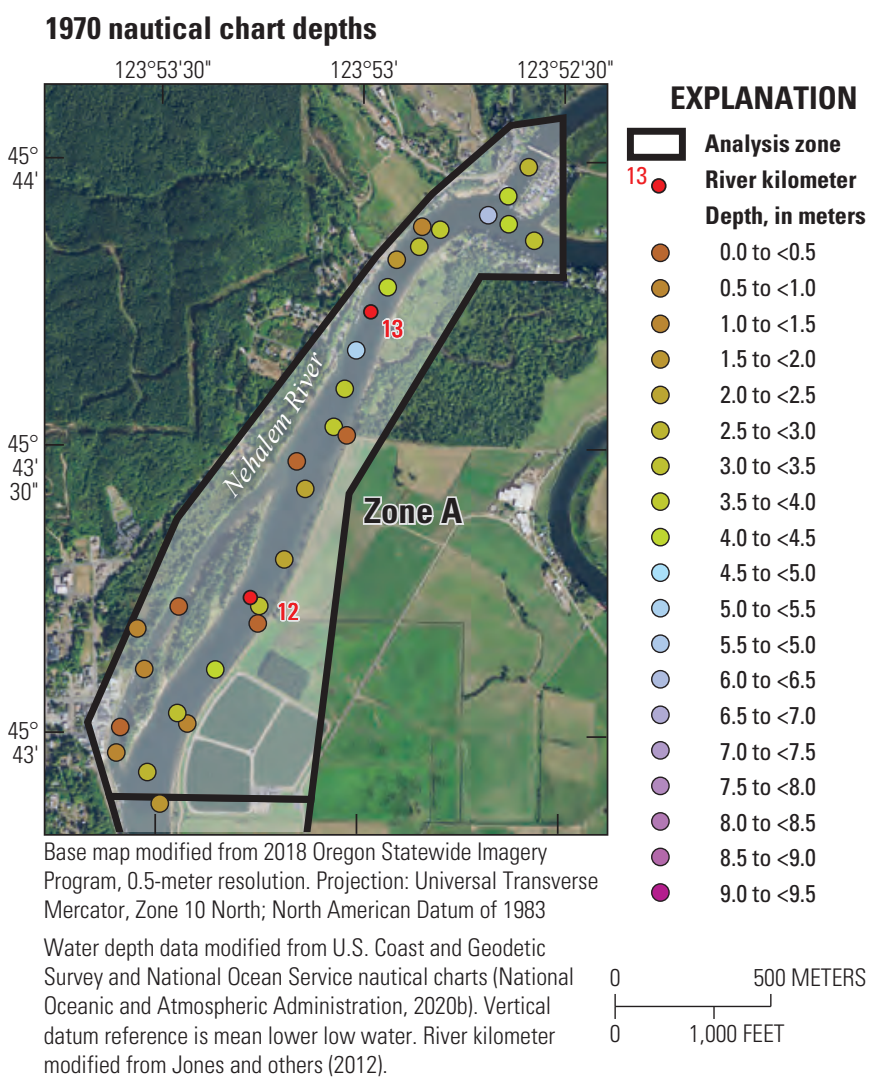

Figure 14. Water depths from the U.S. Coast and Geodetic Survey nautical chart publication for 1970 covering the zone $A$ analysis area for the Nehalem Bay, northwestern Oregon.

\section{Zone B}

Nautical charts with sufficient data in zone B for analysis were those for $1947(\mathrm{n}=18)$ and $1970(\mathrm{n}=20)$. In the 1947 chart, 12 percent of all water depth values, near the upstream end of the zone along the channel margins, were less than 1 $\mathrm{m}$ deep, while the remaining values (83 percent) ranged from 1 to $5 \mathrm{~m}$ and were distributed evenly throughout the channel (table 7; figs. $13 B$ and 15; app. 1). One additional deep depth value $(5.5 \mathrm{~m})$ was near the upstream end of the zone. On the 1970 nautical chart, the proportion of depth values less than 1 $\mathrm{m}$ increased from 12 to 30 percent. Additionally, values in the $1-2 \mathrm{~m}$ range increased (from 22 to 30 percent), whereas values in the $2-5 \mathrm{~m}$ range decreased (from 61 to 35 percent). Most of the water depth values less than $2 \mathrm{~m}$ shown on the 1970 charts are downstream of the Highway 101 bridge. One relatively deep value $(5.8 \mathrm{~m})$ was at the upstream end of the zone on the 1970 chart. Although the range of depths indicated by the two charts increased slightly, from $5.2 \mathrm{~m}$ in 1947 to $5.5 \mathrm{~m}$ in 1970 , the median depth within the zone was $0.6 \mathrm{~m}$ less in 1970 .

\section{Zone C}

Nautical charts for 1891, 1947, and 1970 were evaluated for water depths in zone C. On the 1891 chart, 20 water depth values $(\mathrm{n}=20)$, ranging from 0.3 to $4.0 \mathrm{~m}$, were mapped, with 25 percent of the values less than $1 \mathrm{~m}$ (table 7; figs. $13 C$ and 16; app. 1). Values upstream of Rkm 8.0 ranged up to 1.2 $\mathrm{m}$, whereas values downstream of Rkm 8.0 ranged from 2.7 to $4.0 \mathrm{~m}$. In the 1947 nautical chart, overall plotted depths $(n=31)$ ranged from 0.3 to $3.4 \mathrm{~m}$. The proportion of values less than $1 \mathrm{~m}$ increased from 25 percent on the 1891 chart to 35 percent on the 1940 chart. The overall spatial distribution of water depths plotted on the charts in zone $\mathrm{C}$ was more variable in 1891 than in 1947, meaning depths did not break out into distinct areas with deeper and shallower values. The median depths for zone $\mathrm{C}$ decreased ( became shallower) by $0.3 \mathrm{~m}$ between the 1891 and 1947 charts.

On the 1970 nautical chart, water depths plotted in zone $\mathrm{C}(\mathrm{n}=39)$ ranged from 0.3 to $6.4 \mathrm{~m}$. Two relatively deep values were at Rkm 9.2 (5.5 m) and Rkm 7.7 (6.4 m). The percentage of values less than $1 \mathrm{~m}$ (26 percent) in 1970 chart were similar to that on the 1891 chart. However, the number of values with depths between 1 and $5 \mathrm{~m}$ increased slightly, accounting for 69 percent of all mapped depths, compared to 65 percent in the 1947 charts. Additionally, between the 1947 and 1970 charts, water depths in the 3-5 m range increased from 0 to 15 percent of all plotted values, whereas the water depths in the 1-3 m range decreased from 65 to 54 percent, suggesting general deepening in this zone during the 23-year period between the chart dates. Accordingly, the median depth in zone $\mathrm{C}$ increased (became deeper) from 1.5 to $2.4 \mathrm{~m}$ from 1947 to 1970. 


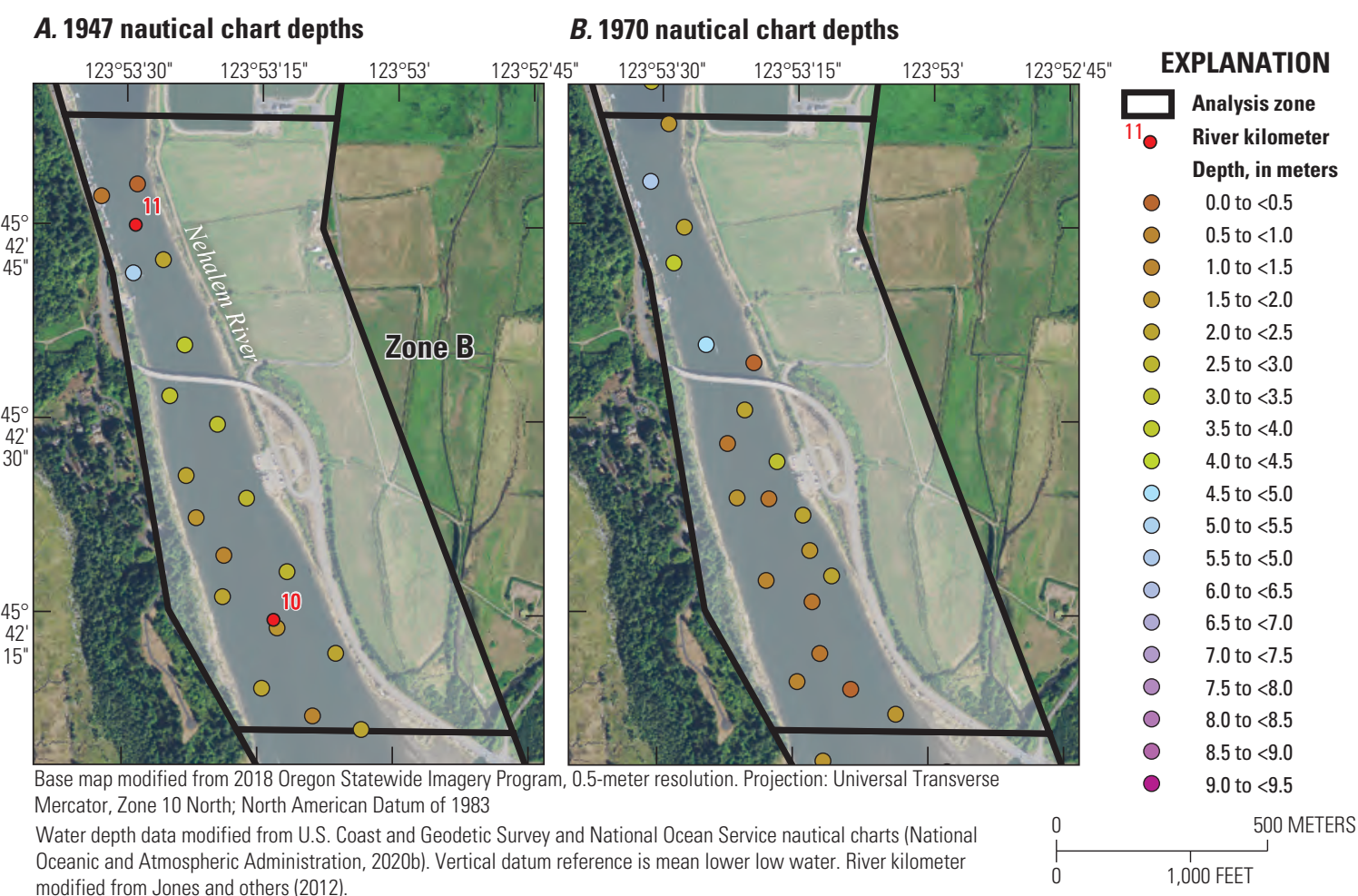

Figure 15. Water depths from the U.S. Coast and Geodetic Survey nautical chart publications for $1947(A)$ and 1970 (B) covering the zone B analysis area for the Nehalem Bay, northwestern Oregon.

\section{Zone D}

Nautical charts from 1891, 1947, and 1970 were used to evaluate the distribution of water depth values in zone $\mathrm{D}$. The 1891 chart depicts depths that range from 0.3 to $2.1 \mathrm{~m}$ $(\mathrm{n}=11)$, with depths less than $1 \mathrm{~m}$ accounting for 45 percent of the distribution (table 7; figs. 13D and 16; app. 1). Substantial deepening in zone D had occurred by 1947 ( $\mathrm{n}=13)$, coinciding with shallowing in the main channel in zone $\mathrm{C}$ for this same period. Water depths less than $1 \mathrm{~m}$ still accounted for 31 percent during this period; however, four 3.0-m-depth values were plotted and overall distribution of depth greater than 1 $\mathrm{m}$ values increased from 59 to 65 percent. The median water depth between 1891 and 1947 increased by $0.6 \mathrm{~m}$. Changes between the 1947 and $1970(n=11)$ nautical charts show the reverse pattern, with substantial shallowing in zone $\mathrm{D}$, coinciding with deepening in zone $\mathrm{C}$ of the main Nehalem River channel. In the 1970 chart, the maximum depth was only 1.2 $\mathrm{m}$ and 82 percent of the depth values were less than $1 \mathrm{~m}$. The median depth decreased from 1947 to 1970 by $1.5 \mathrm{~m}$.

\section{Zone $\mathrm{E}$}

Within Zone E, depths are included on the 1891 and 1970 nautical charts. On the 1891 chart $(n=43), 23$ percent of the plotted depths were shallower than $1 \mathrm{~m}$, and the remaining depth values ranged up to a maximum depth of $4.0 \mathrm{~m}$ (table 7; fig. $13 E$; fig. 17; app. 1). The deepest depth values plotted in zone E during 1891 (about 2.7-4.0 m) appear to follow the thalweg along the southern part of the Nehalem Bay between Rkm 7.1 and 6.2 before crossing and following the northern part of the bay between Rkm 5.2 and 4.7. Depths plotted on the 1970 nautical chart $(\mathrm{n}=48)$ primarily show shallowing throughout the zone relative to the 1891 chart, although two relatively deeper depth values were included $(4.6 \mathrm{~m}$ at $\mathrm{Rkm}$ 6.3 and $4.9 \mathrm{~m}$ at Rkm 5.0). Relatively shallow (less than $1 \mathrm{~m}$ ) depth values increased from 23 to 69 percent between the two charts, while depth values between 1 and $5 \mathrm{~m}$ decreased to 31 percent. The median depths decreased (or shallowed) from 1.8 to $0.9 \mathrm{~m}$ between the charts.

\section{Zone F}

Nautical charts evaluated for zone F include the 1891, 1947, 1970, 1990, and 2004 publications. However, within the upper portion of zone $\mathrm{F}$ ( $\mathrm{Rkm} 4.7$ to about $\mathrm{Rkm} 2.6$ ), the chart from 1947 appears to utilize the 1891 soundings, although substantial updates downstream of Rkm 2.6 are apparent in subsequent charts. The distribution of depth values depicted on the 1947 nautical chart are included in table 7 and fig. $13 F$ but are not reported in the results here because they partly utilize 1891 soundings. Charts from 1970, 1990, and 2004 include updates in zone $\mathrm{F}$ where new water depth values are apparent, although some values near the upstream boundary did not change (fig. 18). However, because most of the water depths reflect conditions in the chart publication, the distributions 


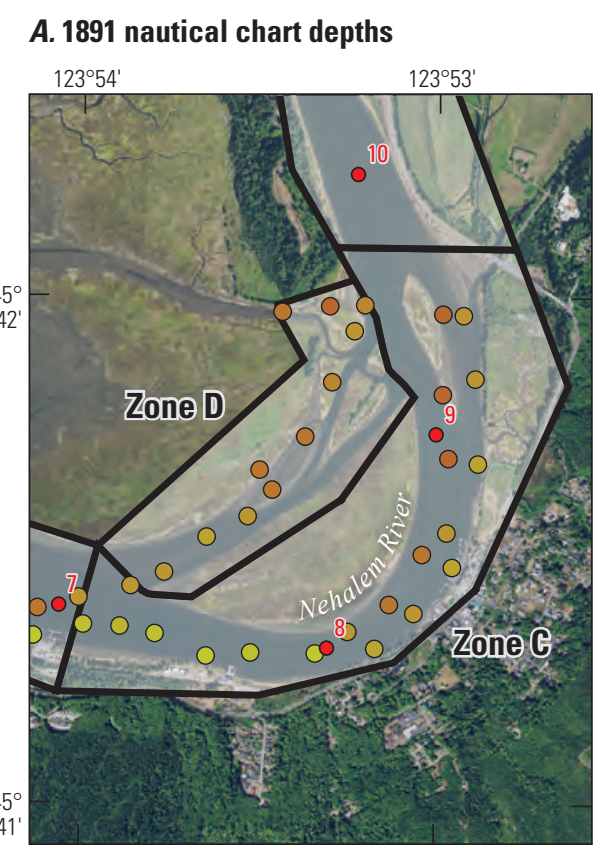

Base map modified from 2018 Oregon Statewide Imagery Program, 0.5-meter resolution. Projection: Universal Transverse Mercator, Zone 10 North; North American Datum of 1983

Water depth data modified from U.S. Coast and Geodetic Survey and National Ocean Service nautical charts (National Oceanic and Atmospheric Administration, 2020b). Vertical datum reference is mean lower low water. River kilometer modified from Jones and others (2012).
B. 1947 nautical chart depths
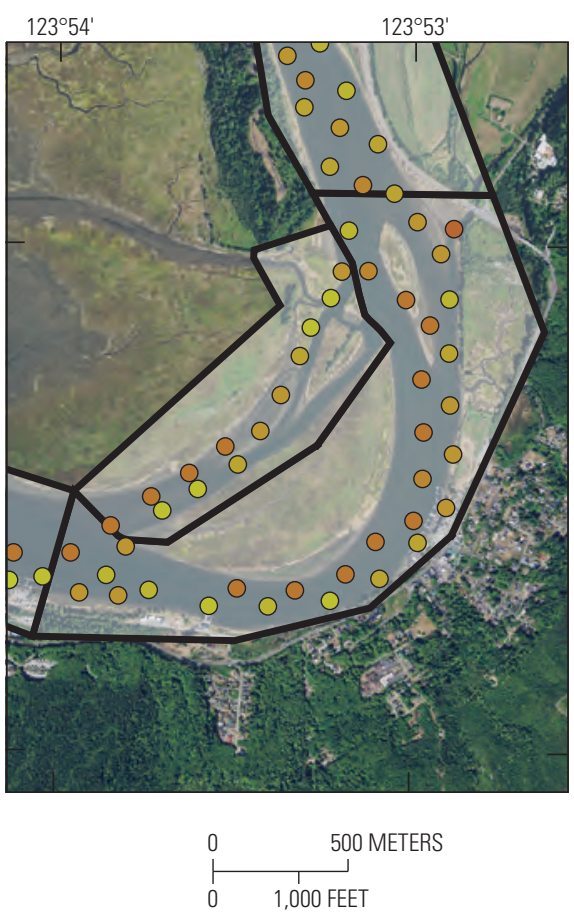

C. 1970 nautical chart depths

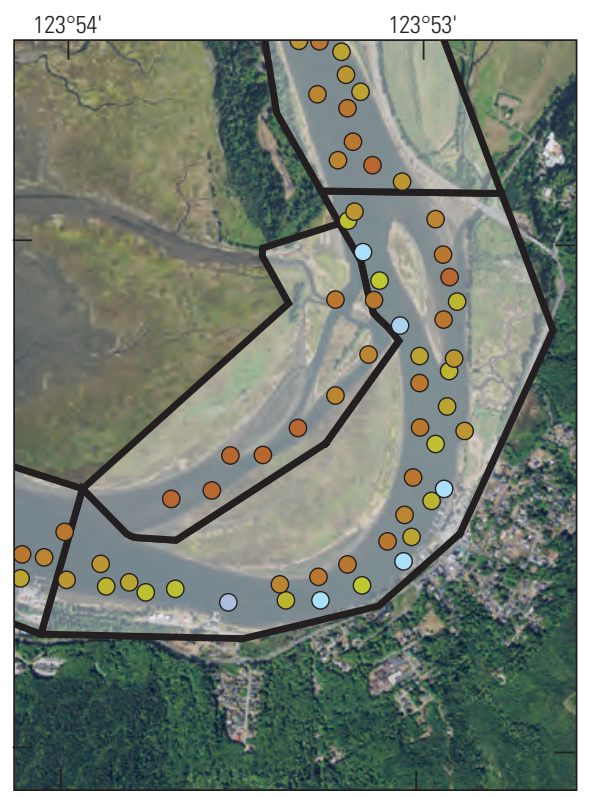

EXPLANATION

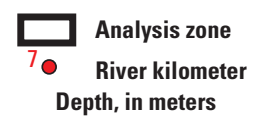

$$
\begin{array}{lll}
0.0 \text { to }<0.5 & \bigcirc & 5.0 \text { to }<5.5 \\
0.5 \text { to }<1.0 & \bigcirc & 5.5 \text { to }<5.0 \\
1.0 \text { to }<1.5 & \bigcirc & 6.0 \text { to }<6.5 \\
1.5 \text { to }<2.0 & \bigcirc & 6.5 \text { to }<7.0 \\
2.0 \text { to }<2.5 & \bigcirc & 7.0 \text { to }<7.5 \\
2.5 \text { to }<3.0 & \bigcirc & 7.5 \text { to }<8.0 \\
3.0 \text { to }<3.5 & \bigcirc & 8.0 \text { to }<8.5 \\
3.5 \text { to }<4.0 & \bigcirc & 8.5 \text { to }<9.0 \\
4.0 \text { to }<4.5 & \bigcirc & 9.0 \text { to }<9.5 \\
4.5 \text { to }<5.0 & &
\end{array}
$$

Figure 16. Water depths from the U.S. Coast and Geodetic Survey nautical chart publications for $1891(A), 1947(B)$, and $1970(C)$ covering the zone $\mathrm{C}$ and $\mathrm{D}$ analysis areas for the Nehalem Bay, northwestern Oregon.

of water depth values from those charts are reported here. While most charts exclude water depths for various parts of the Nehalem Bay, there is a notable data gap in water depths within the shallow mudflat area downstream of Fishery Point along the eastern (left) side of the channel from about $\mathrm{Rkm}$ 4.7 to 3.2 .

Water depths within zone F on the 1891 nautical chart $(n=57)$ range from 0.3 to $5.5 \mathrm{~m}$. Eighteen percent of the depth values depicted depths less than $1 \mathrm{~m}$ and 7 percent were greater than $5 \mathrm{~m}$. Within the 1970 chart, the total range of depths ( 0.3 to $5.2 \mathrm{~m}, \mathrm{n}=77)$ was similar to those plotted on the 1891 chart. However, the distribution of depths shifted towards a larger percent of depths less than $1 \mathrm{~m}$ (31 percent) and depths greater than $5 \mathrm{~m}$ only accounted for 1 percent of the depth values. The median water depth value decreased from $2.7 \mathrm{~m}$ on the 1891 chart to $2.1 \mathrm{~m}$ on the 1970 chart (about $0.6 \mathrm{~m}$ shallower). The 1990 chart in zone $\mathrm{F}(\mathrm{n}=71)$ spans a larger range of depths, with depth values as deep as $7.3 \mathrm{~m}$ (near the downstream boundary of the zone at $\mathrm{Rkm} \mathrm{1.2).}$ This chart had slightly fewer depth values that were less than $1 \mathrm{~m}$ in depth (27 percent) and more water depths greater than $5 \mathrm{~m}$ (3 percent) compared to the 1970 chart. Between the 1970 and 1990 charts, the median water depth value decreased an additional $0.3 \mathrm{~m}$ from 2.1 to $1.8 \mathrm{~m}$. Within the 2004 nautical chart $(n=68)$, water depths ranged 0.3 to $6.1 \mathrm{~m}(1.2 \mathrm{~m}$ less than for the 1990 chart), though the overall water depths greater than $5 \mathrm{~m}$ increased from 3 to 9 percent. A 2 and 4 percent reduction in water depths for the $0-1$ and $1-5 \mathrm{~m}$ ranges (respectively) since the 1990 nautical chart was also observed. The median depth between the 1990 and 2004 charts increased (deepened) by $0.3 \mathrm{~m}$. 


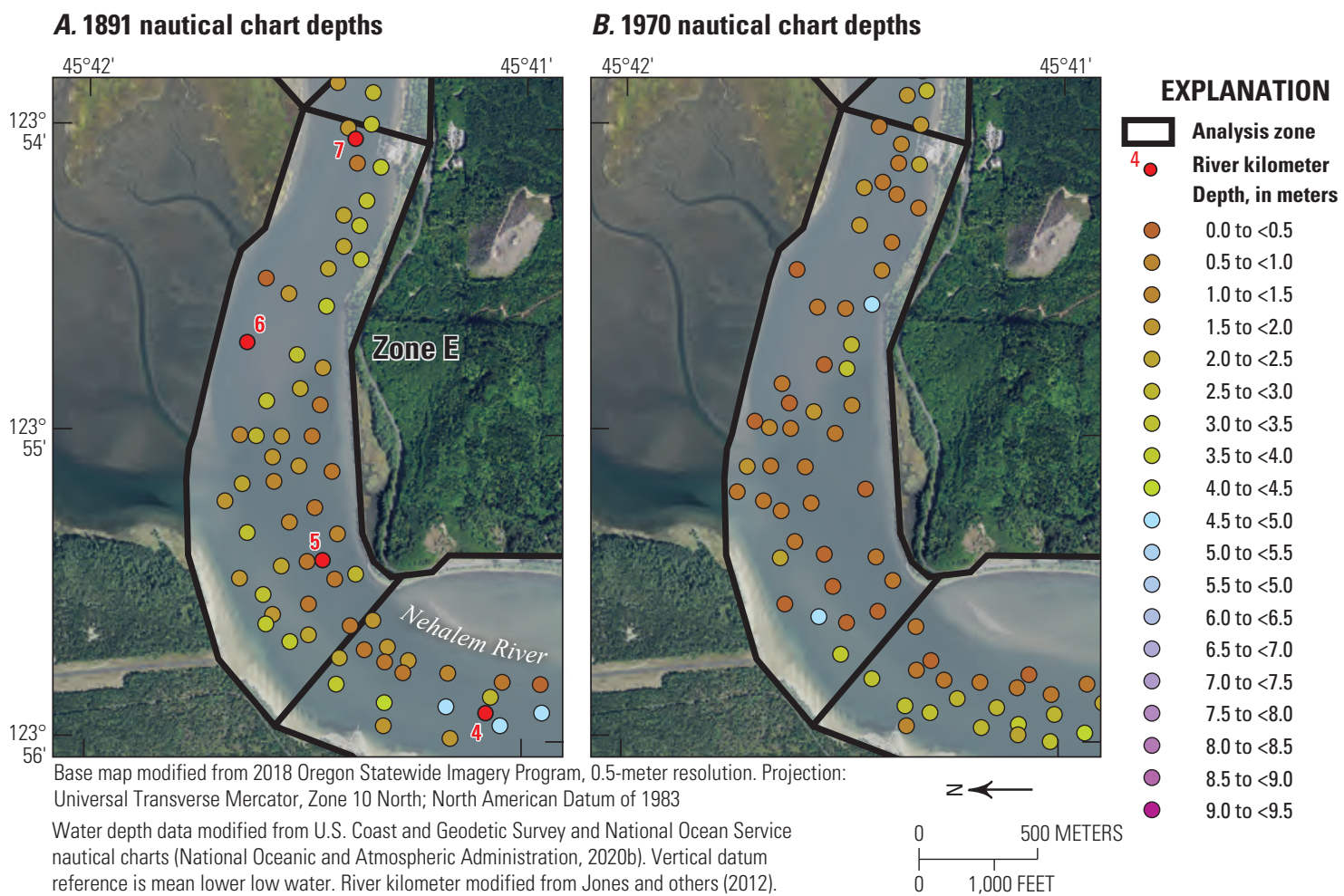

Figure 17. Water depths from the U.S. Coast and Geodetic Survey nautical chart publications for $1891(A)$ and 1970 (B) covering the zone E analysis area for the Nehalem Bay, northwestern Oregon.

\section{Zone G}

Nautical charts evaluated for zone $\mathrm{G}$ include the publications from 1891, 1947, 1970, 1990, and 2004. Direct comparison of the distribution of depth values from 1891 to 1947 is made difficult by the substantial local changes in depths introduced by the north jetty, constructed in 1918, and the south jetty, constructed in 1916 (table 1; fig. 7). Results for the 1891 chart are reported here, but the charts published in 1947 and later are more directly comparable.

The 1891 chart depicts two outlets from the Nehalem Bay to the Pacific Ocean. The north outlet generally aligns with the location of the present-day channel between the jetties, whereas the southern, longer, and narrow outlet was converted to beach by 1939 (based on visual inspection of a 1939 aerial photograph mosaic published by Jones and others [2012]). Water depths within zone $\mathrm{G}(\mathrm{n}=20)$ ranged from 1.5 to $9.1 \mathrm{~m}$ (8 depth values along the south channel outlet ranged from 1.5 to $4.9 \mathrm{~m}$; 12 depth values in the north channel range from 1.8 to $9.1 \mathrm{~m}$ ) with a median depth of $3.5 \mathrm{~m}$ (table 7; figs. $13 G$ and 19; app. 1). More than 90 percent of the water depth values were within the $1-5$-m-range. The deepest depth values (6.7 and $9.1 \mathrm{~m}$ ) were mapped upstream of Rkm 0.8 near the boundary of zones G and F. By the 1947 nautical chart, jetties had been constructed and the outlet of the Nehalem Bay to the Pacific Ocean was a single channel. Fourteen $(n=14)$ water depth values ranged in depth from 0.3 to $8.8 \mathrm{~m}$. The shallowest water depths were mostly located on the inside of the bend along the north jetty. The relative abundance of shallow (less than $1 \mathrm{~m}$ ) and deep (greater than $5 \mathrm{~m}$ ) water depths increased from the 1891 chart (0-21 and 10-57 percent, respectively). The median depth for depth values in zone $\mathrm{G}$ for 1947 (5.3 m) had increased (deepened) by $1.8 \mathrm{~m}$ since 1891 . The 1970 nautical chart $(\mathrm{n}=14)$ showed slightly deeper minimum $(0.6 \mathrm{~m})$, median $(6.2 \mathrm{~m})$, and maximum $(9.4 \mathrm{~m})$ depths compared with the 1947 chart, though the number and location of shallow and deep depths remained similar, with deeper depth values along the southern jetty and shallower depth values along the northern portion of the zone. Likewise, the overall distribution of depth values in the $1990(n=13)$ and $2004(n=9)$ charts showed a similar spatial pattern. However, maximum depths for zone $\mathrm{G}$ decreased to $8.5 \mathrm{~m}$ in 1990 and $7.9 \mathrm{~m}$ in 2004. The median depth also decreased ( became shallower) between 1970 and 1990 by $2.5 \mathrm{~m}$ but increased (or deepened) by $2.7 \mathrm{~m}$ from 1990 to 2004. 


\section{A. 1891 nautical chart depths}

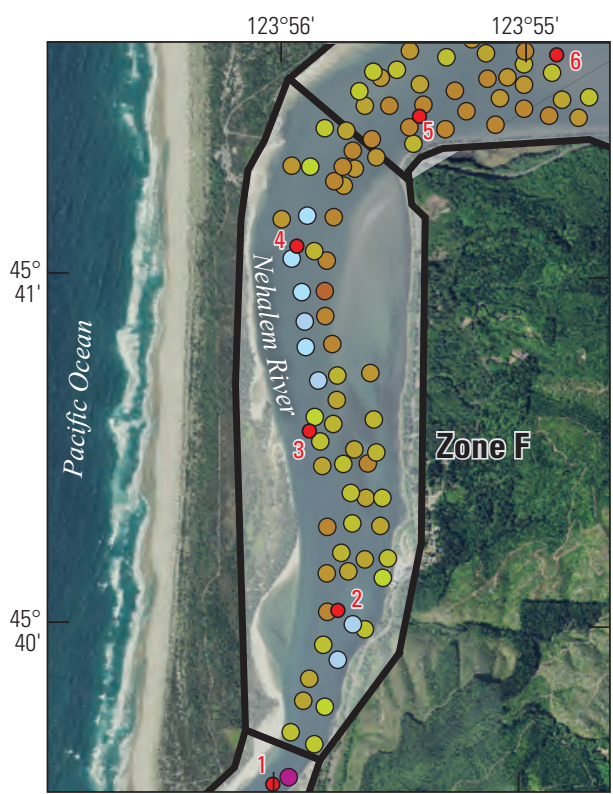

D. 1990 nautical chart depths

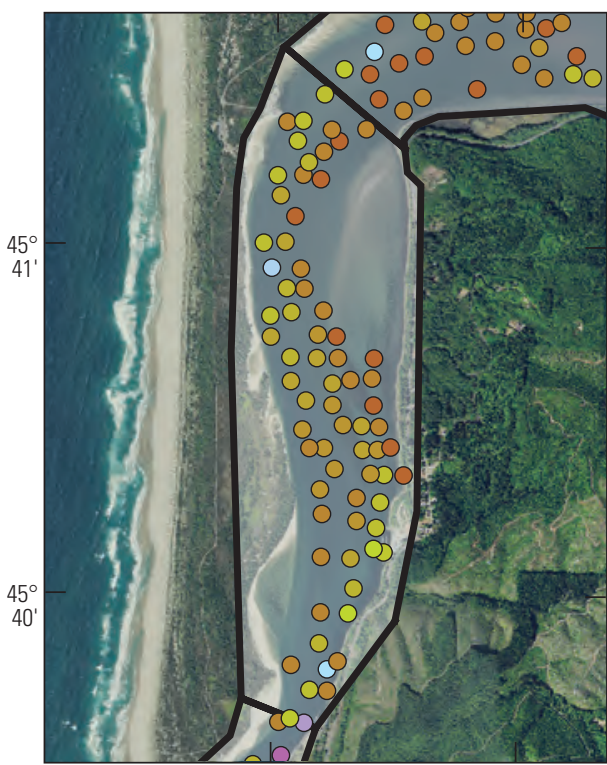

Base map modified from 2018 Oregon Statewide Imagery Program, 0.5-meter resolution. Projection: Universal Transverse Mercator, Zone 10 North; North American Datum of 1983

Water depth data modified from U.S. Coast and Geodetic Survey and National Ocean Service nautical charts (National Oceanic and Atmospheric Administration, 2020b). Vertical datum reference is mean lower low water. River kilometer modified from Jones and others (2012).

\section{B. 1947 nautical chart depths}

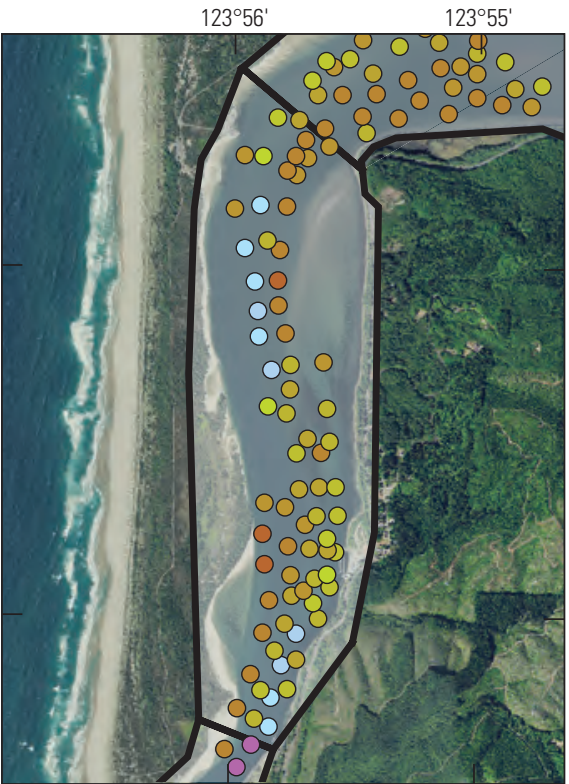

E. 2004 nautical chart depths

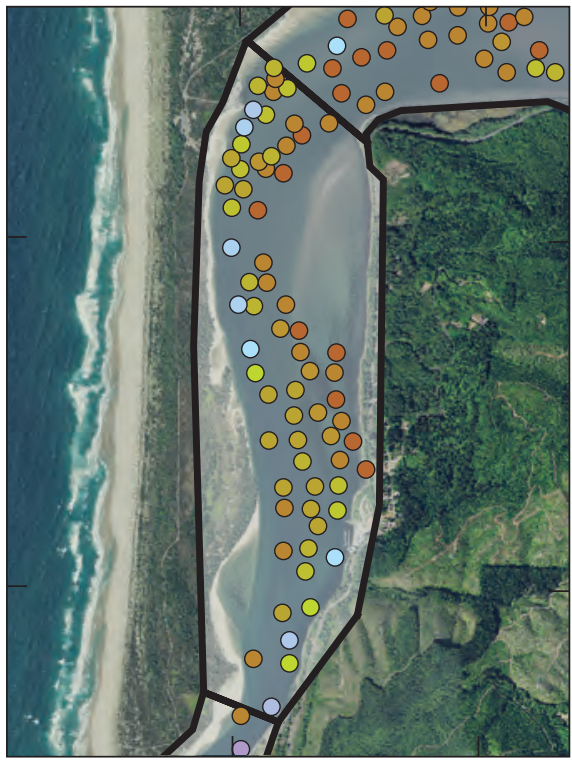

$\stackrel{0}{\sim} \quad 500$ METERS
C. 1970 nautical chart depths

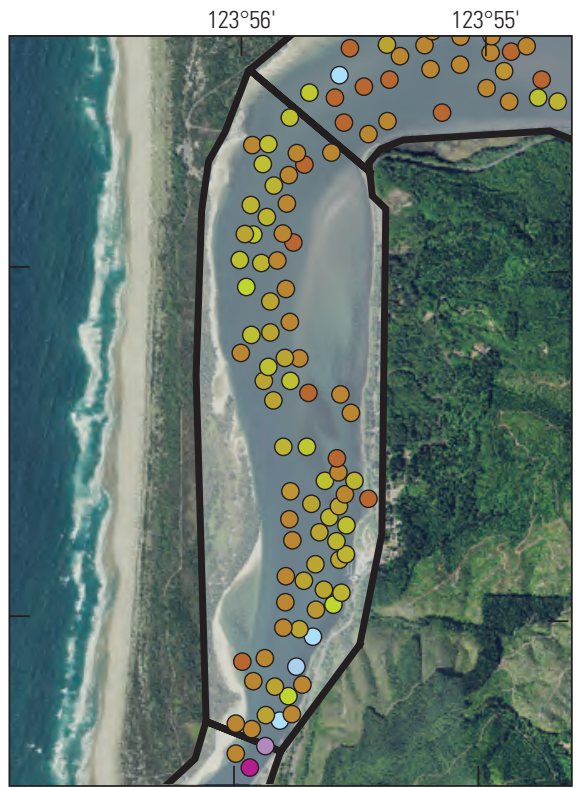

\section{EXPLANATION}

Analysis zone

River kilometer

Depth, in meters

0.0 to $<0.5$

0.5 to $<1.0$

1.0 to $<1.5$

1.5 to $<2.0$

2.0 to $<2.5$

2.5 to $<3.0$

3.0 to $<3.5$

3.5 to $<4.0$

4.0 to $<4.5$

4.5 to $<5.0$

5.0 to $<5.5$

5.5 to $<5.0$

6.0 to $<6.5$

6.5 to $<7.0$

7.0 to $<7.5$

7.5 to $<8.0$

8.0 to $<8.5$

8.5 to $<9.0$

9.0 to $<9.5$

Figure 18. Water depths from the U.S. Coast and Geodetic Survey nautical chart publications for $1891(A), 1947^{*}(B), 1970(C), 1990^{* *}$ $(D)$, and $2004^{* *}(E)$ covering the zone $\mathrm{F}$ analysis area for the Nehalem Bay, northwestern Oregon. ${ }^{*}$ No updates to water depths in zone F upstream of Rkm 2.6 between 1891 and 1947 but substantial updates in the lower part of the zone. ${ }^{*}$ Substantial updates to water depths within the zone between the 1970-1990 and 1990-2004 maps but repeat depth values are present near the upstream boundary. 


\section{A. 1891 nautical chart depths}
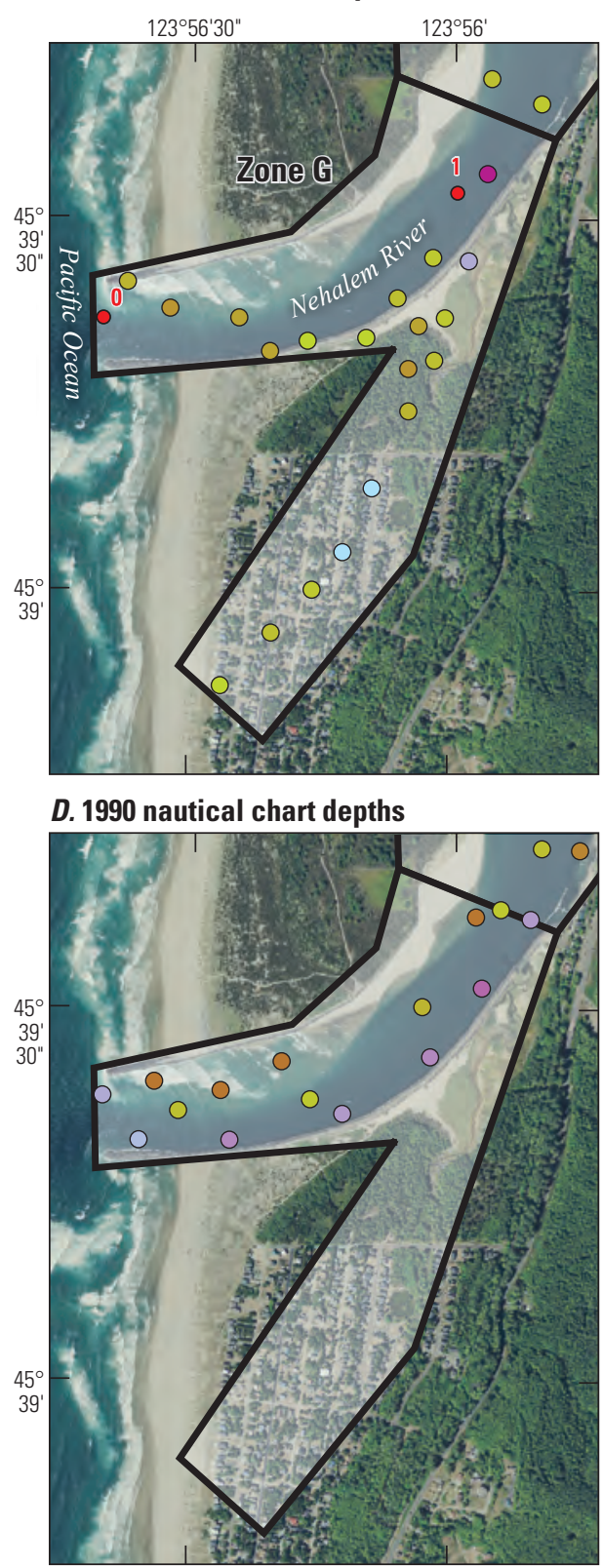

Base map modified from 2018 Oregon Statewide Imagery Program, 0.5-meter resolution. Projection: Universa Transverse Mercator, Zone 10 North; North American Datum of 1983

Water depth data modified from U.S. Coast and Geodetic Survey and National Ocean Service nautical charts (National Oceanic and Atmospheric Administration, 2020b). Vertical datum reference is mean lower low water. River kilometer modified from Jones and others (2012).

\section{B. 1947 nautical chart depths}

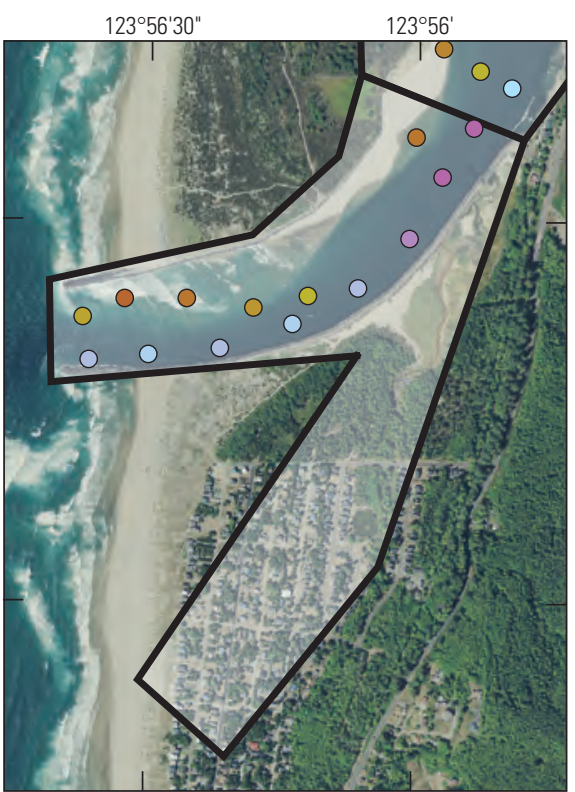

E. 2004 nautical chart depths

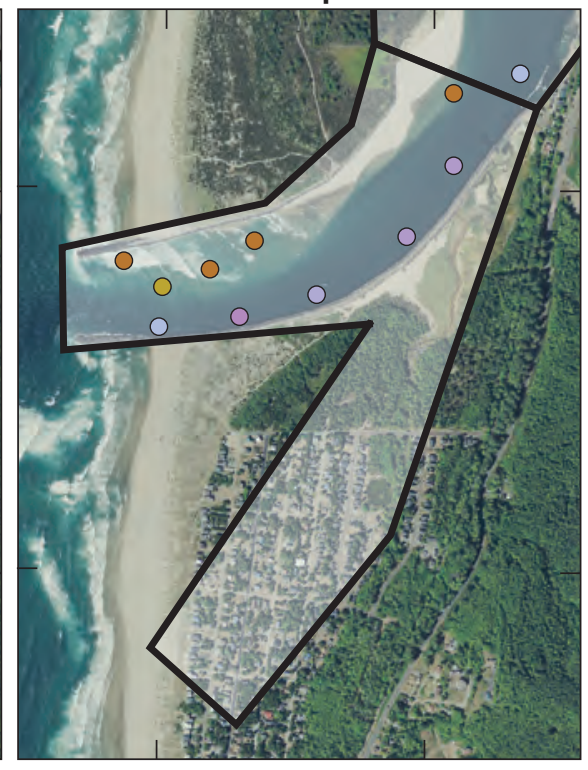




\section{Summary and Discussion}

Results from this study provide:

(1) An assessment of changes in the spatial patterns in bed elevations and volumes of eroded and deposited sediment in the Nehalem Bay using bathymetric surveys from 1957 and 2019 (USCGS, 1958a, b; National Oceanic and Atmospheric Administration, 2020a; Gordon and others, 2020a, b),

(2) Documentation of water depth changes in the Bay from 1891 to 2004 using nautical charts (National Oceanic and Atmospheric Administration, 2020b; table 3),

(3) A foundation for assessing how reach-scale geomorphic processes in the Bay, such as lateral thalweg migration, relate to local changes in bed elevations, and

(4) Baseline datasets for tracking future changes in bed elevations, the channel thalweg, and sediment erosion and deposition in the Bay.

Six key findings of the study include the following:

(1) After the completion of the jetties in 1918, the mouth of the Nehalem River changed from a dual mouth outlet to a single outlet; however, water depths near the mouth have continued to vary over time. The nautical chart from 1891 shows the mouth of Nehalem River with two outlets to the Pacific Ocean (fig. 7). The mouth became a single outlet by 1947 . Within this single outlet stabilized by the jetties, water depths have changed over time. Water depths in zone F decreased (became shallower) in the periods 1891-1947 and 1947-1970 but increased (became deeper) during these same periods in zone $\mathrm{G}$ between the jetties (fig. 19; table 7). Water depths in both zones decreased between 1970 and 1990 and then increased between 1990 and 2004. Despite these fluctuations in water depths over time, the deepest water depths within the Nehalem Bay were typically in zones F and G. The effects of the jetties on overall sediment transport and hydraulics in the Nehalem Bay were not assessed by this study, but deepening and shallowing of water at the Nehalem Bay's entrance to the Pacific Ocean may reflect either changes in sediment erosion or deposition, owing to changing streamflow, tides, and sediment inputs from marine and watershed sources, or may simply reflect differences in the MLLW (mean lower low water) datum over time (fig. 6). Changes in sediment transport and hydraulics at the river mouth may have caused changes in patterns of hydraulics and sediment erosion and deposition upstream in the Nehalem Bay, but this relation was not investigated by this study.

(2) Bed-elevation changes in the thalweg (the deepest part of the channel) varied longitudinally between 1957 and 2019. Bed elevations along the thalwegs cannot be compared directly to identify specific locations of sediment erosion or deposition because the location of the thalweg changed from 1957 to 2019. However, longitudinal comparison of the thalweg elevations is useful for understanding changes in the depth of the thalweg between Rkm 10.8 and 4.4. In both surveys, the deepest part of the thalweg was near Rkm 7.7 to 7.6. Relative to the 1957 thalweg, bed elevations along the 2019 thalweg were higher (by as much as $1.6 \mathrm{~m}$ ) in some and lower (by about $2.0 \mathrm{~m}$ ) in other locations (fig. 9). These maximum differences in thalweg elevation occurred upstream of Rkms 8.6, though elevation differences of more than 1 $\mathrm{m}$ occurred farther downstream. Despite these changes, the maximum bed elevation of most of the thalweg in 1957 and 2019 was less than -1.0 m (NAVD 88) (fig. 9), which indicates no substantial change in the minimum thalweg elevation. Other thalweg characteristics, such as width or cross-sectional area, may also have changed, but such changes were not assessed by this study.

(3) The Nehalem Bay thalweg migrated laterally between 1891 and 2019, but the locations and magnitude of thalweg migration varied. The thalweg migrated by more than $350 \mathrm{~m}$ in places between 1957 and 2019. Between Rkm 9.6 and 9.0, the thalweg migrated from the left side channel to the right side channel along Snag Island (figs. 8, 10, 11, 16). Between Rkm 9.7 and 7.1, the water depth analysis of nautical charts indicates the thalweg occupied the Lazarus Island Slough in 1947 but moved into the main channel by 1970 (fig. 13; table 7). Between Rkm 7.6 and 5.6, the thalweg migrated northward and follows the right side of the channel near the large mudflats as of 2019. Between Rkm 5.6 and 4.4, the thalweg migrated southward toward the left side of the channel. Analyses of aerial photographs acquired from 1939 to 2009 also indicated lateral channel migrations between Rkm 6.2 and 2.2 (Jones and others, 2012). Because the bathymetric surveys span a long period (62 years), the frequency and rates of thalweg migration cannot be determined by this study (app. 3). The thalweg in most of the Nehalem Bay is likely to continue to migrate in the future in response to changes in tide, streamflow, and sediment supply from marine and watershed sources. Exceptions may include areas where infrastructure reduces the potential for channel migration, for example, at the upstream end of Lazarus Island Slough.

(4) Locations of sediment erosion and deposition correspond with the changes in thalweg position over time. Where the thalweg migrated between the downstream end of Lazarus Island and downstream of Fishery Point (Rkm 7.4-4.4), deposition filled in the thalweg of the 1957 survey, whereas erosion occurred mainly along the thalweg of the 2019 survey (fig. 11). Deposition in the previous 1957 thalweg ranged up to $4.5 \mathrm{~m}$ near $\mathrm{Rkm}$ 5.0, whereas erosion in the 2019 thalweg ranged up to $4.3 \mathrm{~m}$ near Rkm 7.8. 
(5) The area of the Nehalem Bay from upstream of the Highway 101 bridge to downstream of Fishery Point (Rkms 10.8-4.4) had net sediment deposition in the 62 years between the 1957 and 2019 bathymetric surveys. At the 95 percent confidence interval, the estimated net volume change was $230,000 \mathrm{~m}^{3}$, indicating net sediment deposition between Rkm 10.8 and 4.4 (table 6; figs. 11 and 12). However, the error estimated for the 95 percent confidence interval is $315,000 \mathrm{~m}^{3}$ (or 137 percent) and does not preclude the possibility that net erosion may have occurred. The mean annual volume of inferred sediment deposition for 1957-2019 is 3,710 m/ year for the 95 percent confidence intervals. These mean annual volumes do not account for event-based changes in the thalweg position or bed elevation, such as rapid erosion or deposition of sediment that can occur during floods, as well as repeated erosion and deposition of sediment that may have occurred multiple times over the 62 -year period. As these surveys did not cover the shallow marshes, mudflats, tide channels, or channel margins of the Nehalem Bay, changes in sediment erosion and deposition within those areas could not be evaluated.

(6) The mean annual rate of increasing sediment thickness is slightly greater than but similar to that of sea level rise. The mean net change in sediment thickness at the 75 and 95 percent confidence intervals ranged from 0.10 to $0.11 \mathrm{~m}$ within the area analyzed (Rkm 10.8-4.4) between 1957 and 2019. Over the 62-year period analyzed, the mean annual thickness change is about 1.6-1.8 $\mathrm{mm} /$ year, while approximate relative sea level rise in the Nehalem Bay is approximately $0.9 \pm 1.0 \mathrm{~mm} /$ year (Peck and others, 2020).

Collectively, the results from this study emphasize that the channel bed in the Nehalem Bay is not static, as illustrated by the lateral and vertical changes in the thalweg and changes in the distributions of water depths over time (figs. $9,10,11$; table 7). Though changes in water depths are not a direct measure of erosion or deposition, documentation of the distribution of historical water depths values combined with comparison of bed elevation changes shed light on possible future changes. On the basis of the channel changes from 1891 to 2019 quantified in this study, changes in thalweg position and patterns of sediment erosion and deposition are expected in the future as the Nehalem Bay continues to respond to different influences, such as streamflow, tides, sea level rise, sediment supplied from marine and watershed sources, and human actions. Continued sediment accumulation in the Nehalem Bay is also expected as estuaries are natural depositional areas at the nexus of rivers and the ocean (Dyer, 1995). As such, the surveys from 1957 and 2019 provide a foundation for documenting and evaluating future changes in the Nehalem Bay and supporting management decisions (app. 3). Changes in thalweg position likely explain some of the estimated net sediment deposition in the Nehalem Bay from 1957 to 2019, but deposition may also partly reflect the local geomorphology.
The increases in bed elevation and apparent deposition at Rkm 9.4 and 9.0 indicate that sediment inputs exceed sediment export (at least locally). Here, the channel is relatively laterally stable and narrow (about $200 \mathrm{~m}$ wide). Slower velocities in the left channel around Snag Island and downstream end of Snag likely resulted in sediment deposition (see cross-sections 9.4 and 9.0, respectively; figs. 8 and 10).

Although this study did not investigate the underlying mechanisms for changes in thalweg position and sediment storage within the Nehalem Bay, changes in streamflow and sediment inputs are well-established factors that can lead to changes in thalweg position and patterns of sediment erosion and deposition (Cooper, 2002; Jackson and others, 2013; Guo and others, 2015). Many natural events and human actions since 1700 likely contributed to the channel changes and patterns of sediment deposition and erosion detected in this study (table 1). Floods contribute to both sediment deposition and erosion. Floods cause sediment deposition because they increase the delivery of sediment from hillslopes to river channels, yet they also erode banks and exert energy on channel beds. Watershed-scale disturbances, such as forest fires and logging, can also affect sediment deposition and erosion. Large fires (such as the Tillamook Burn between 1931 and 1951 and the Salmonberry Fire in 1945) followed by large flood events (such as those on February 17, 1949, December 21, 1955, and January 25, 1964; Jones and others, 2012) likely contributed sediment from the watershed to the river network. Timber harvesting and associated road building can also contribute sediment inputs by increasing the frequency of landslides (Kelsey and others, 1995), and cause erosion by increasing peak streamflows (Wemple and others, 1996; Jones and Grant, 1996, 2001; Bowling and others, 2000; Safeeq and others, 2020). Other human actions that likely contributed to sediment erosion and channel changes include jetty and revetment construction, dredging, and in-stream gravel mining. Systematically relating and linking past natural events and human actions to channel and sediment changes would be necessary to identify and compare the sediment deposition and erosion rates for different types of natural events and human actions that may affect sediment transport and important infrastructure and habitats in the Nehalem Bay in the future (app. 3).

This study contributes information on changes in bed elevation and patterns of sediment erosion and deposition and adds to other recent studies to increase our understanding of the evolution of Oregon coast estuaries. Peck and others (2020) reported that sedimentation rates in the low and high marshes of the Nehalem Bay are exceeding sea level rise and have some of the fastest sediment-accumulation rates measured on the Oregon Coast. Peck and others (2020) also determined that vertical accretion in Oregon estuaries is driven by relative sea level rise and suspended sediment supply. Of the fifteen Oregon coast estuaries for which data are available (Brophy, 2019), the Nehalem Bay had the third greatest estimated suspended sediment load (224,000 tons/year; Wise, 2018) and second greatest relative suspended sediment load 
(14,900 tons $/$ year $/ \mathrm{km}^{2}$; which was calculated by dividing the suspended sediment load by current estuary area; table 8 ).

Rates of volumetric sediment change within the wetted channel of the Nehalem Bay determined in this study are difficult to compare directly with rates determined or estimated in other studies that identify sediment depth accumulation rates through coring and detailed stratigraphy (for example, Peck and others, 2020). Assuming no substantial changes in sediment inputs and streamflow, the Nehalem Bay is likely to continue accumulating sediment, which may prevent the Bay's wetlands and marshes from drowning with sea level rise (Thorne and others, 2018; Peck and others, 2020). As sea level rise accelerates (Nerem and others, 2018), however, uncertainties in the balance between sediment supply and sea level rise will increase. Potential impacts of continued accretion on navigation and estuarine habitats in the Nehalem Bay may warrant further investigation (app. 3).

This study was designed and implemented to gain understanding of historical bed elevation and water depth changes in the Nehalem Bay and inform issues related to recreational navigation. Overall, between 1957 and 2019, the channel thalweg migrated toward the right side of the channel downstream of Lazarus Island and toward the left side of the channel near Nehalem Bay State Park, resulting in erosion along the present-day thalweg position and deposition along the prior thalweg position (figs. 10 and 11). These locations encompass two access points to the Nehalem Bay (near Rkm 7.0 and 4.4) that were near the location of the thalweg in 1957. This study also documented erosion and deposition near other boat ramps and docks where the thalweg had negligible to no lateral migration between 1957 and 2019 (for example, Rkm 10.3 and $\mathrm{Rkm} 8.6$ to 8.4 )

Sediment deposition near boat ramps and docks in the Nehalem Bay may pose navigation challenges during periods of low tide and streamflow. If deposition near boat docks and ramps persists, some sediment management activities (for example, dredging) may be required to maintain existing access locations. Another approach to continuing to provide recreational access to the Nehalem Bay would be to use the information from this study to develop an adaptive plan for recreational access in the Nehalem Bay. For example, the plan could identify sites where access in the future is likely to be substantially affected by sediment deposition based on spatial patterns documented in this study, and sites that are more likely to maintain stable channel bed elevations given the historical patterns of erosion and deposition and local geomorphic setting. Information from this study, coupled with future monitoring (app. 3), could aid in the development of a sediment management or adaptive access plan for the Nehalem Bay.

Table 8. Compilation of present-day (2019) estuary area (excluding diked areas; Brophy, 2019), mean annual suspended sediment loads (Wise, 2018), and relative sediment load for fifteen estuaries along the Oregon coast.

[Mean annual suspended sediment loads were estimated using lithology, mean annual precipitation (1981-2010), and recent wildfire disturbance (2003-12). Relative sediment load was calculated by dividing mean annual suspended sediment loads by present-day estuary area]

\begin{tabular}{lccccc}
\hline \multicolumn{1}{c}{ Basin } & $\begin{array}{c}\text { Estuary area } \\
\text { (square } \\
\text { kilometers) }\end{array}$ & $\begin{array}{c}\text { Estimated mean annual } \\
\text { suspended sentimental load } \\
\text { (tons per year) }\end{array}$ & $\begin{array}{c}\text { Suspended } \\
\text { sediment load } \\
\text { rank }\end{array}$ & $\begin{array}{c}\text { Relative sediment load } \\
\text { (tons per years per square } \\
\text { kilometer) }\end{array}$ & $\begin{array}{c}\text { Relative } \\
\text { sediment load } \\
\text { rank }\end{array}$ \\
\hline Necanicum & 2.7 & 20,100 & 12 & 7,400 & 8 \\
Nehalem & 15.1 & 223,900 & 3 & 14,900 & 2 \\
Tillamook Bay & 42.9 & 264,000 & 2 & 6,200 & 10 \\
Nestucca & 5.9 & 99,300 & 9 & 16,700 & 1 \\
Netarts & 10.7 & 2,500 & 15 & 200 & 15 \\
Sand Lake & 4.4 & 4,100 & 14 & 900 & 14 \\
Salmon & 3.5 & 20,100 & 11 & 5,700 & 11 \\
Siletz & 10.0 & 99,700 & 8 & 10,000 & 5 \\
Yaquina & 20.9 & 46,000 & 10 & 2,200 & 9 \\
Beaver Creek & 1.0 & 6,300 & 13 & 6,500 & 6 \\
Alsea & 13.2 & 110,100 & 7 & 8,400 & 7 \\
Siuslaw & 21.1 & 157,800 & 5 & 7,500 & 4 \\
Umpqua & 41.4 & 495,400 & 1 & 12,000 & 7 \\
Coos & 67.4 & 137,600 & 6 & 2,000 & 3 \\
Coquille & 12.9 & 178,000 & 4 & 13,800 & 7 \\
\hline
\end{tabular}




\section{Conclusions}

Sediment deposition and reductions in water depth have been observed in the Nehalem Bay, along the northern coast of Oregon, in recent decades by the Port of Nehalem. Sediment deposition may result in potential adverse impacts to recreational river navigation, reductions in estuarine habitats for juvenile salmonids, and flood risks for infrastructure. The results and key findings of this study emphasize that bed elevations and water depths within the Nehalem Bay have varied between 1891 and 2019, as illustrated by the lateral and vertical changes in the thalweg and changes in water depths. As the position of the thalweg migrated over time, the locations of sediment erosion and deposition also changed. Between Highway 101 bridge and Fishery Point, net sediment deposition was calculated for the 62 years between the 1957 and 2019 bathymetric surveys and the mean annual rate of increasing sediment thickness is slightly greater than but similar to that of sea level rise. Changes in thalweg position and related patterns of sediment erosion and deposition are expected in the future as the Nehalem Bay continues to respond to changes in tides, sea level, streamflow, and inputs of watershed and marine sediment. Collectively, the results of this study provide a foundation for documenting and evaluating future changes in the Nehalem Bay and prioritizing actions to manage and protect natural resources and recreational access to the Nehalem Bay.

\section{References Cited}

Atwater, B.F., Nelson, A.R., Clague, J.J., Carver, G.A., Yamaguchi, D.K., Bobrowsky, P.T., Bourgeois, J., Darienzo, M.E., Grant, W.C., Hemphill-Haley, E., Kelsey, H.M., Jacoby, G.C., Nishenko, S.P., Palmer, S.P., Peterson, C.D., and Reinhart, M.A., 1995, Summary of coastal geologic evidence for past great earthquakes at the Cascadia subduction zone: Earthquake Spectra, v. 11, no. 1, p. 1-18.

Bernert, J.A., and Sullivan, T.J., 1998, Bathymetric analysis of Tillamook Bay - Comparison among bathymetric databases collected in 1867, 1957, and 1995: Corvallis, Oregon, E\&S Environmental Chemistry, Inc., 23 p.

Bowling, L.C., Storck, P., and Lettenmaier, D.P., 2000, Hydrologic effects of logging in western Washington, United States: Water Resources Research, v. 36, no. 11, p. 3223-3240.
Brophy, L.S., 2019, Comparing historical losses of forested, scrub-shrub, and emergent tidal wetlands on the Oregon coast, USA - A paradigm shift for estuary restoration and conservation: Corvallis, Oregon, Estuary Technical Group, Institute for Applied Ecology, Prepared for the Pacific States Marine Fisheries Commission and the Pacific Marine and Estuarine Fish Habitat Partnership, accessed December 8, 2020, at https://appliedeco.org/report/brophy_2019_oregon tidal_swamp_and_marsh_losses_final_dec2019/.

Buster, N.A., and Morton, R.A., 2011, Historical bathymetry and bathymetric change in the Mississippi-Alabama coastal region, 1847-2009: U.S. Geological Survey Scientific Investigations Map 3154, 13 p. pamphlet.

Cooper, J.A.G., 2002, The role of extreme floods in estuarycoastal behaviour - Contrasts between river- and tidedominated microtidal estuaries: Sedimentary Geology, v. 150, no. 1-2, p. 123-137, accessed September 27, 2020.

Coulton, K.G., Williams, P.B., and Benner, P.A., 1996, An environmental history of the Tillamook Bay estuary and watershed: Prepared for the Tillamook Bay National Estuary Project, Garibaldi, Oregon, Tillamook Bay National Project Technical Report, $58 \mathrm{p}$.

Dyer, K.R., 1995, Sediment transport processes in estuaries, chap. 14 of Perillo, G.M.E., ed., Developments in sedimentology-geomorphology and sedimentology of estuaries: Amsterdam, Elsevier B.V., v. 53. p. 423-449, accessed August 30, 2021, at https://doi.org/10.1016/S00704571(05)80034-2.

Farnell, J.E., 1980, Tillamook Bay rivers navigability study: Salem, Oregon, Division of State Lands, 35 p.

Farnell, J.E., 1981, Nehalem, Necanicum, Nestucca navigability studies: Salem, Oregon, Division of State Lands, 13 p.

Ferdun, G.S., 2007, Historical time line, chap. 3 of Ferdun, G.S., ed., The Nehalem estuary and adjacent wetlands, 44 p., accessed September 7, 2021, at https://nwc.nehalem.org/ wp-content/uploads/2020/10/Ferdun-2007-NehalemHistorical-Overview.pdf

Fisher, P.F., and Tate, N.J., 2006, Causes and consequences of error in digital elevation models: Progress in Physical Geography, v. 30, no. 4, p. 467-489.

Foxgrover, A.C., Higgens, S.A., Ingraca, M.K., Jaffe, B.E., and Smith, R.E., 2004, Deposition, erosion, and bathymetric change in South San Francisco Bay: 1958-1983: U.S. Geological Survey Open-File Report 2004-1192, 25 p., accessed August 30, 2021, at https://doi.org/10.3133/ ofr20041192. 
Gordon, G.W., Haluska, P.A., and Overstreet, B.T., 2020a, Digital elevation model of the Nehalem Bay near Wheeler, Oregon 2019: U.S. Geological Survey data release, accessed August 30, 2021, at https://doi.org/10.5066/P9VJOGM1.

Gordon, G.W., Haluska, P.A., and Overstreet, B.T., 2020b, Single-beam echosounder bathymetry of the Nehalem Bay near Wheeler, Oregon 2019: U.S. Geological Survey data release, accessed August 30, 2021, at https://doi.org/10.5066/P9W96Z24.

Guo, L., van der Wegen, M., Roelvink, D.J.A., Wang, Z.B., and He, Q., 2015, Long-term, process-based morphodynamic modeling of a fluvio-deltaic system, part I-The role of river discharge: Continental Shelf Research, v. 109, p. $95-111$.

Hempel, L., 2020, Elevation and elevation-change maps of Fountain Creek, southeastern Colorado, 2015-19: U.S. Geological Survey Scientific Investigations Map 3456, 10 sheets, 9 p., accessed August 30, 2021, at https://doi.org/10.3133/sim3456.

Hengl, T., 2006, Finding the right pixel size: Computers \& Geosciences, v. 32, no. 9, p. 1283-1298, accessed August 10, 2020 https://doi.org/10.1016/ j.cageo.2005.11.008.

Jackson, N.L., Nordstrom, K.F., Feagin, R.A., and Smith, W.K., 2013, Coastal geomorphology and restoration: Geomorphology, v. 199, p. 1-7, accessed September 27, 2020.

Jaffe, B.E., and Foxgrover, A.C., 2006, Sediment deposition and erosion in south San Francisco Bay, California from 1956 to 2005: U.S. Geological Survey Open-File Report 2006-1287, 24 p., accessed August 30, 2021, at https://doi.org/10.3133/ofr20061287.

Jaffe, B.E., Smith, R.E., and Foxgrover, A.C., 2007, Anthropogenic influence on sedimentation and intertidal mudflat change in San Pablo Bay, California: 1856-1983: Estuarine, Coastal and Shelf Science, v. 73, no. 1-2, p. $175-187$.

Johnson, J., and Maser, J., 1999, Nehalem River watershed assessment: Portland, Oregon, Prepared by the Environmental Sciences and Resources Department, Portland State University for the Upper and Lower Nehalem River Watershed Councils, accessed August 30, 2021, at http://web.pdx.edu/ maserj/project/project1/1.htm.

Jones, J.A., and Grant, G.E., 1996, Peak flow responses to clear-cutting and roads in small and large basins, Western Cascades, Oregon: Water Resources Research, v. 32, no. 4, p. 959-974.
Jones, J.A., and Grant, G.E., 2001, Comment on "Peak flow responses to clearcutting and roads in small and large basins, Western Cascades, Oregon": Water Resources Research, v. 37, no. 1, p. 179-180, accessed August 30, 2021, at https://doi.org/10.1029/2000WR900115.

Jones, K.L., Keith, M.K., O'Connor, J.E., Mangano, J.F., and Wallick, J.R., 2012, Preliminary assessment of channel stability and bed-material transport in the Tillamook Bay tributaries and Nehalem River basin, northwestern Oregon: U.S. Geological Survey Open-File Report 2012-1187, 120 p., accessed August 30, 2021, at https://doi.org/10.3133/ ofr20121187.

Kelsey, H.M., Coghlan, M.C., and Pitlick, J., 1995, Geomorphic analysis of streamside landsliding in the Redwood Creek basin in Nolan, M., Kelsey, H., and Marron, D., eds., Geomorphic processes and aquatic habitat in the Redwood Creek basin, northwestern California: U.S. Geological Survey Professional Paper 1454, p. JI-J12.

Komar, P.D., McManus, J., and Styllas, M., 2004, Sediment accumulation in Tillamook Bay, Oregon, Natural Processes versus Human Impacts: The Journal of Geology, v. 112, no. 4, p. 455-469, accessed August 30, 2021.

L3 Communications SeaBeam Instruments, 2000, Multibeam sonar, theory of operation: East Walpole, Massachusetts, L3 Communications SeaBeam Instruments, 107 p., accessed September 25, 2020, at https://www3.mbari.org/data/ mbsystem/sonarfunction/SeaBeamMultibeamTheoryOpe ration.pdf.

Miller, R.R., 2010, Is the past present? Historical splashdam mapping and stream disturbance detection in the Oregon Coastal Province: Corvallis, Oregon, Oregon State University, Master of Science Thesis, 110 p.

National Oceanic and Atmospheric Administration, 2003, Computational techniques for tidal datums handbook: National Oceanic and Atmospheric Administration, National Ocean Service, Center for Operational Oceanographic Products and Services, Special Publication NOS CO-OPS 2, 98 p., plus appendices, accessed August 8, 2020, at http s://tidesandcurrents.noaa.gov/publications/Computational_ Techniques_for_Tidal_Datums_handbook.pdf.

National Oceanic and Atmospheric Administration, 2020a, Bathymetric data viewer: National Oceanic and Atmospheric Administration, website, accessed May 27, 2020, at https://maps.ngdc.noaa.gov/viewers/bathymetry/.

National Oceanic and Atmospheric Administration, 2020b, Historical Map and Chart Collection: National Oceanic and Atmospheric Administration, Office of the Coast Survey, website, accessed May 27, 2020, at https://historicalcharts .noaa.gov/. 
National Oceanic and Atmospheric Administration, 2020c, National geodetic survey-history overview: National Oceanic and Atmospheric Administration, National Geodetic Survey, website, accessed September 14, 2020, at https://geodesy.noaa.gov/web/about_ngs/history/ index.shtml.

National Oceanic and Atmospheric Administration, 2020d, NADCON-North American datum conversion utility: National Oceanic and Atmospheric Administration, National Geodetic Survey, accessed September 19 at https://geodesy .noaa.gov/TOOLS/Nadcon/Nadcon.shtml.

National Oceanic and Atmospheric Administration, 2020e, Online vertical datum transformation: National Oceanic and Atmospheric Administration, National Geodetic Survey, accessed September 2, 2020, at https://vdatum.noaa.gov/ vdatumweb/vdatumweb? $\mathrm{a}=18480362018060$.

National Oceanic and Atmospheric Administration, 2020f, NOAA tide predictions users guide: National Oceanic and Atmospheric Administration, National Ocean Service, accessed October 30, 2020, at https://tidesandcurrents .noaa.gov/PageHelp.html\#: : text=Harmonic $\% 20$ sta tions $\% 20$ are $\% 20$ stations $\% 20$ with, directly $\% 20$ from $\% 20$ the $\% 20$ harmonic $\% 20$ constants.

National Oceanic and Atmospheric Administration, 2020g, Tidal datums: National Oceanic and Atmospheric Administration, National Ocean Service, website, accessed May 27, 2020, at https://tidesandcurrents.noaa.gov/datum options.html.

National Oceanic and Atmospheric Administration, 2020h, Tide station page for Brighton station, Oregon, Station ID: 9437815: National Oceanic and Atmospheric Administration, National Ocean Service, website, accessed September 23, 2020, at https://tidesandcurrents.noaa.gov/ stationhome.html?id=9437815.

National Oceanic and Atmospheric Administration, 2020i, Tide station page for Crescent City station, California, Station ID: 9419750: National Oceanic and Atmospheric Administration, National Ocean Service, website, accessed September 23, 2020, at https://tidesandcurrents.noaa.gov/ stationhome.html?id=9419750.

National Oceanic and Atmospheric Administration, 2020j, Tide station page for Garibaldi station, Oregon, Station ID: 9437540: National Oceanic and Atmospheric Administration, National Ocean Service, website, accessed September 23, 2020, at https://tidesandcurrents.noaa.gov/ stationhome.html?id=9437540
National Oceanic and Atmospheric Administration, 2020k, Tide station page for Nehalem station, Oregon, Station ID: 9437908: National Oceanic and Atmospheric Administration, National Ocean Service, website, accessed September 23, 2020, at https://tidesandcurrents.noaa.gov/ stationhome.html?id=9437908.

National Oceanic and Atmospheric Administration, 20201, Tide station page for North Fork station, Oregon Station ID: 9437815: National Oceanic and Atmospheric Administration, National Ocean Service, website, accessed September 23, 2020, at https://tidesandcurrents.noaa.gov/ stationhome.html?id=9437954.

Nelson, A.R., Hawkes, A.D., Sawai, Y., Engelhart, S.E., Witter, R., Grant-Walter, W.C., Bradley, L.-A., Dura, T., Cahill, N., and Horton, B., 2020, Identifying the greatest earthquakes of the past 2000 years at the Nehalem River Estuary, Northern Oregon Coast, USA: Open Quaternary, v. 6, no. 2, p. 1-30, accessed September 23, 2020. http://doi. org/10.5334/oq. 70 .

Nerem, R.S., Beckley, B.D., Fasullo, J.T., Hamlington, B.D., Masters, D., and Mitchum, G.T., 2018, Climate-changedriven accelerated sea-level rise detected in the altimeter era: Proceedings of the National Academy of Sciences of the United States of America, v. 115, no. 9, p. 2022-2025.

Oregon Statewide Imagery Program, 2018, Oregon Statewide Imagery Program 2018 aerial photography: Oregon Geospatial Enterprise Office, accessed November 4, 2020, at https://www.oregon.gov/geo/Pages/imagery.aspx.

Oregon State Department of Forestry, 1983, From Tillamook burn to Tillamook State Forest, 1933-1983: Salem, Oregon, Oregon State Department of Forestry, $16 \mathrm{p}$.

Oregon Department of State Lands, 2017, Heads of tide dataset. Oregon Spatial Data Library, accessed October 21, 2020.

Peck, E.K., Wheatcroft, R.A., and Brophy, L.S., 2020, Controls on sediment accretion and blue carbon burial in tidal saline wetlands-Insights from the Oregon coast, USA: Journal of Geophysical Research. Biogeosciences, v. 125, accessed August 30, 2021. https://doi. org/10.1029/2019JG005464.

Perillo, G.M.E., 1995, Geomorphology and sedimentology of estuaries - An introduction, in Perillo, G.M.E., ed., Developments in sedimentology-geomorphology and sedimentology of estuaries: Elsevier, v. 53, chap. 1, p. 1-16, accessed September 10, 2020, at https://www.scienced irect.com/science/article/pii/S0070457105800214. 
R2 Resource Consultants, Inc., 2005, Upper Nehalem watershed assessment, Part I-Assessment: R2 Resource Consultants, Inc., in association with Lee Benda and Associates, Inc., Prepared for the Oregon Department of Forestry, 360 p., accessed September 18, 2020, at htt ps://www.oregon.gov/ODF/Documents/WorkingForests/ UpperNehalemWatershedAnalysis.pdf.

Riverscapes Consortium, 2019, Geomorphic Change Detection Software version 7.4.4.0: Riverscapes Consortium, version 7 available and accessed September 1, 2021, at http:// gcd.riverscapes.xyz/.

Safeeq, M., Grant, G.E., Lewis, S.E., and Hayes, S.K., 2020, Disentangling effects of forest harvest on long-term hydrologic and sediment dynamics, western Cascades, Oregon: Journal of Hydrology, v. 580, no. 124259, 16 p., https://doi.org/10.1016/j.jhydrol.2019.124259.

Sherwood, C.R., Jay, D.A., Harvey, R.B., Hamilton, P., and Simenstad, C.A., 1990, Historical changes in the Columbia River Estuary: Progress in Oceanography, v. 25, no. 1-4, p. 299-352.

Thorne, K., MacDonald, G., Guntenspergen, G., Ambrose, R., Buffington, K., Dugger, B., Freeman, C., Janousek, C., Brown, L., Rosencranz, J., Holmquist, J., Smol, J., Hargan, K., and Takekawa, J., 2018, U.S. Pacific coastal wetland resilience and vulnerability to sea-level rise: Science Advances, v. 4, no. 2, accessed August 30, 2021 https://doi.org/10.1126/sciadv.aao3270.

Thrush, S., Hewitt, J., Cummings, V., Ellis, J., Hatton, C., Lohrer, A., and Norkko, A., 2004, Muddy watersElevating sediment input to coastal and estuarine habitats: Frontiers in Ecology and the Environment, v. 2, no. 6, p. 299-306, accessed August 30, $2021 \mathrm{https} / / /$ doi.org/ 10.1890/1540-9295(2004)002[0299:MWESIT]2.0.CO;2.

U.S. Army Corps of Engineers, 2020, Building Strong at the Nehalem River: U.S. Army Corps of Engineers, website, accessed September 16, 2020, at https://www.nwp.usace .army.mil/Locations/Oregon-Coast/Nehalem-River/.

U.S. Coast and Geodetic Survey, 1958a, Descriptive report to accompany hydrographic surveys H-8368 (WCFP 05156) and H-8369 (WCFP 052556), Nehalem River, Oregon, Project 13820-H-8368: Department of Commerce, U.S. Coast and Geodetic Survey, 26 p.

U.S. Coast and Geodetic Survey, 1958b, Descriptive report to accompany hydrographic surveys H-8368 (WCFP 05156) and H-8369 (WCFP 052556), Nehalem River, Oregon, Project 13820-H-8369: Department of Commerce, U.S. Coast and Geodetic Survey, 28 p.
U.S. Geological Survey, 2020, USGS Water Data for the Nation: National Water Information System, web interface, accessed August 30, 2021, at https://waterdata .usgs.gov/nwis.

Van der Wal, D., and Pye, K., 2003, The use of historical bathymetric charts in a GIS to assess morphological change in estuaries: The Geographical Journal, v. 169, no. 1, p. 21-31.

Wallick, J.R., O'Connor, J.E., Anderson, S., Keith, M., Cannon, C., and Risley, J.C., 2011, Channel change and bed-material transport in the Umpqua River basin, Oregon: U.S. Geological Survey Scientific Investigations Report 2011-5041, 110 p., accessed August 30, 2021, at https://doi.org/10.3133/sir20115041.

Wemple, B.C., Jones, J.A., and Grant, G.E., 1996, Channel network extension by logging roads in two basins, western Cascades, Oregon: Water Resources Bulletin, v. 32, no. 6, p. 1195-1207, accessed August 30, 2021 https://doi.org/ 10.1111/j.1752-1688.1996.tb03490.x.

Wheaton, J.M., 2008, Uncertainty in morphological sediment budgeting of Rivers: Southampton, University of Southampton, Ph.D. thesis, 412 p.

Wheaton, J.M., Brasington, J., Darby, S.E., and Sear, D.A., 2010, Accounting for uncertainty in DEMs from repeat topographic surveys-Improved sediment budgets: Earth Surface Processes and Landforms, v. 35, p. 136-156.

Wilson, G.L., and Richards, J.M., 2006, Procedural documentation and accuracy assessment of bathymetric maps and area/capacity tables for small reservoirs: U.S. Geological Survey Scientific Investigations Report 2006-5208, 24 p., accessed August 30, 2021, at https://doi.org/10.3133/ $\operatorname{sir} 20065208$.

Wise, D.R., 2018, Updates to the suspended sediment SPARROW model developed for western Oregon and northeastern California: U.S. Geological Survey Scientific Investigations Report 2018-5156, 23 p., accessed November 4, 2020, at https://doi.org/10.3133/sir20185156.

Zimmerman, M., and Benson, J.L., 2013, Smooth Sheets: How to work with them in a GIS to derive bathymetry, features and substrates: National O ceanic and Atmospheric Administration, National Marine Fisheries Service, NOAA Technical Memorandum NMFS-AFSC-249, 52 p. 



\section{Appendix 1. Table of Water Depths by Zone from Nautical Charts}

Appendix 1 contains a table of the percentages of waterdepth values depicted on nautical charts for 1891, 1947, 1970, 1990, and 2004 for the Nehalem Bay, Oregon, summarized by 0.5 -meter bins for seven analysis zones. 


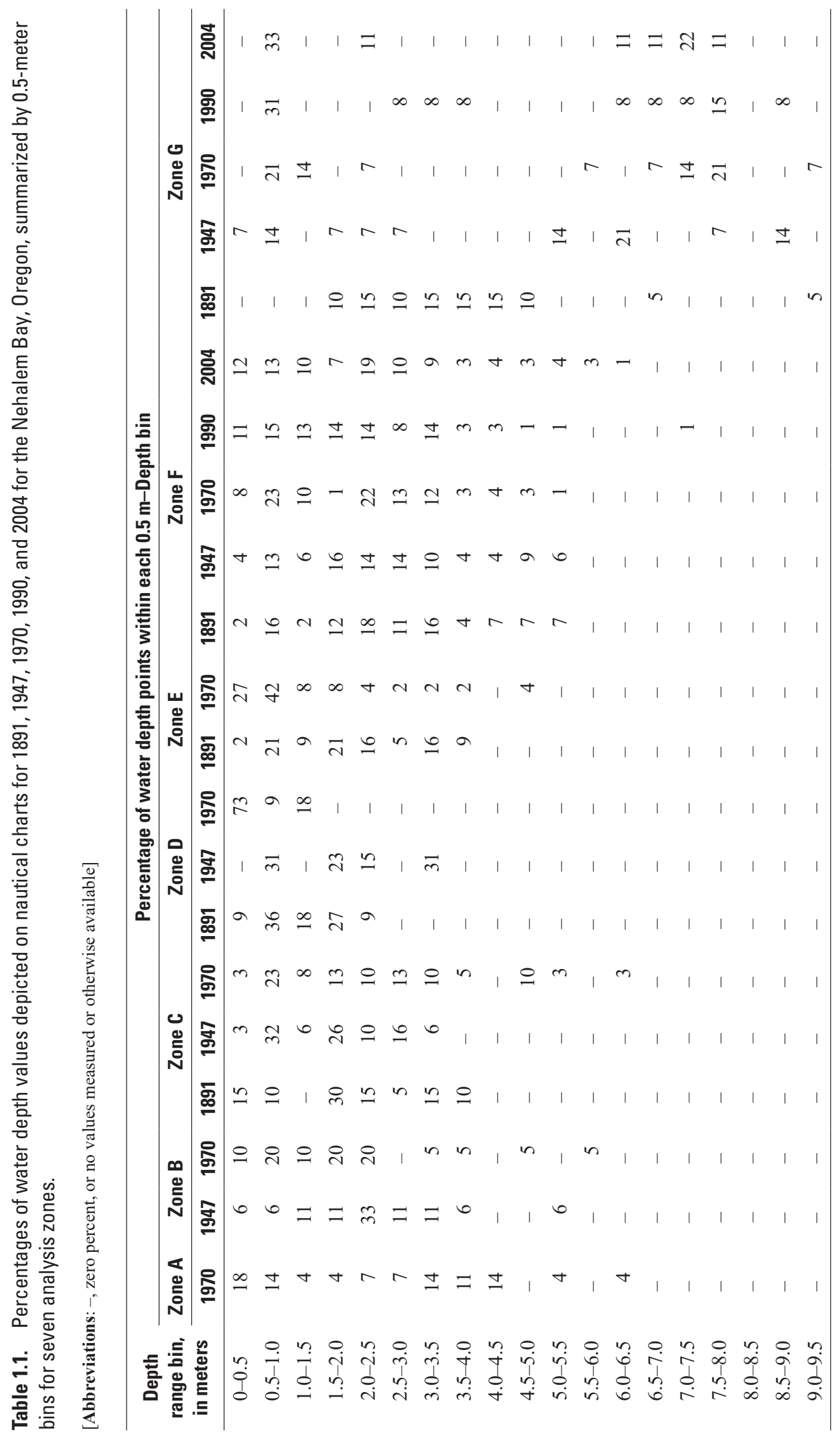




\section{Appendix 2. Water-Depth Map for the Nehalem Bay, 2019}

Appendix 2 contains a map of water depths for river kilometers 10.6-4.4 of the Nehalem Bay, northwest Oregon.

\section{References Cited}

Gordon, G.W., Haluska, P.A., and Overstreet, B.T., 2020a, Digital elevation model of the Nehalem Bay near Wheeler, Oregon 2019: U.S. Geological Survey data release, accessed August 30, 2021, at https://doi.org/10.5066/P9VJOGM1.
Gordon, G.W., Haluska, P.A., and Overstreet, B.T., 2020b, Single-beam echosounder bathymetry of the Nehalem Bay near Wheeler, Oregon 2019: U.S. Geological Survey data release, accessed August 30, 2021, at https://doi.org/ 10.5066/P9W96Z24.

Jones, K.L., Keith, M.K., O'Connor, J.E., Mangano, J.F., and Wallick, J.R., 2012, Preliminary assessment of channel stability and bed-material transport in the Tillamook Bay tributaries and Nehalem River Basin, northwestern Oregon: U.S. Geological Survey Open-File Report 2012-1187, 120 p., accessed August 30, 2021, at https://doi.org/10.3133/ ofr20121187. 


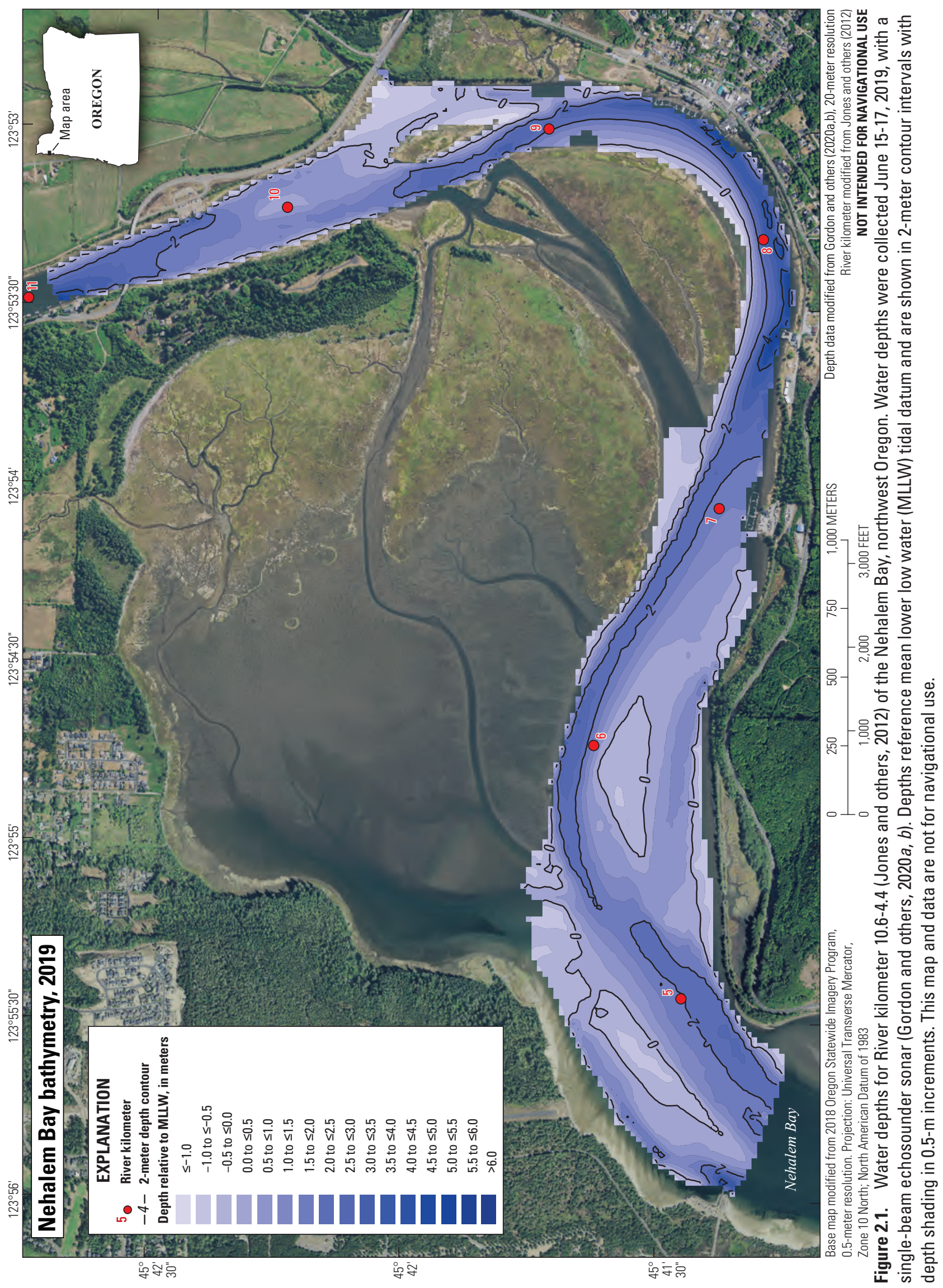




\section{Appendix 3. Approaches for Addressing Outstanding Questions}

Results of this study provide a foundation for understanding water depth changes in the Nehalem Bay from 1891 to 2004 and changes in bed elevations and estimated volumes of eroded and deposited sediment from 1957 to 2019. Some examples of outstanding questions include the following:

(1) What are the sources of sediment to the Nehalem Bay?

(2) What historical events are associated with changes in thalweg position and patterns of sediment erosion and deposition?

(3) Do present-day rates of sediment deposition and erosion exceed historical rates?

(4) What is the frequency, magnitude, and duration of flood events that lead to changes in thalweg position?

(5) What other factors are important for understanding thalweg migration dynamics?

(6) What are the implications of changes in thalweg position and sediment erosion and deposition patterns for flood hazards and recreational navigation?

(7) Are habitats for juvenile salmonids and other important species in the Nehalem Bay influenced by the changes in sediment erosion and deposition?

Potential next steps to address these outstanding questions are outlined below.

(1) Document bed elevation and water depth changes over time. The bathymetric surveys from 1957 and 2019 provide a foundation for assessing changes. The completion of similar surveys tied to common horizontal and vertical datums in the future would be necessary to determine the frequency, duration, and magnitude of flood events that cause changes in bed elevation, thalweg position, and sediment deposition and erosion patterns and provide updated recreational navigation information for the Nehalem Bay. Such surveys may focus on areas on interest to the Port of Nehalem and for recreational access.

(2) Identify and document areas of changes that are important for infrastructure and natural resources that were not captured by the analyses made in the current study. This study was unable to assess sedimentation changes in the mudflats and marshes north of Lazarus Island and downstream of Fishery Point, along channel margins, and in tide channels, owing to the lack of coverage by the previous surveys and nautical charts. Yet, these areas may be important for natural resources in the Nehalem Bay. Collecting high-resolution aerial photographs, ground-based photographs, or water surface elevation data (such as Roegner and others, 2008) that are tied to tide and streamflow levels over time are examples of monitoring approaches that could be used to collect baseline and repeat data in these shallow or inaccessible areas to support more detailed analyses. For example, the collection of repeat ground-based photographs at established locations using standard protocols (for example, Shaff and others, 2007), including a vertical scale within the field of view (such as staff plates), would be helpful for documenting sediment or water-level changes over time. An established program of repeat photograph points could utilize local citizens to aid in obtaining the photographs.

(3) Quantify the sediment loads entering the Nehalem Bay from upstream river sources by building a sediment budget. A sediment budget describes the type (grainsizes, organic and inorganic sediments) and magnitude of sediment delivered to Nehalem Bay from its major tributaries in comparison with the hydraulic capacity of the channel to carry this sediment. A sediment budget is the necessary first step in understanding how sediment erosion, deposition, and transport varies spatially, in relation to natural and anthropogenic influences (for example, geology, gradient, land use), and temporally under different hydrological or management conditions. One approach for developing a sediment budget that quantifies the watershed contributions of fine sediment (sand, silt, and clay) is to monitor streamflow and sediment at strategically located gaging stations. Two key steps in this approach would be: (1) the collection of 2-3 years of continuous streamflow, discrete suspended sediment concentrations (SSC), and continuous turbidity (a measure of water clarity; Anderson, 2007; Bragg and others, 2007; Schenk and Bragg, 2014; Sobieszczyk and others, 2015; Schenk and others, 2016) or other suspended sediment surrogates (Gray and Gartner, 2009; Wood and Teasdale, 2013) on the Nehalem and North Fork Nehalem Rivers, and (2) analyses relating suspended sediment concentrations (a high-cost dataset) and SSC surrogates (lower cost datasets) and streamflow to estimate sediment loads. Assessments of the quantity of riversourced sediment exiting the bay to the Pacific Ocean to construct a sediment budget within the estuary would require more resources and different techniques to address the complexity of tide and streamflow (for example, Wright and Schoellhamer, 2005).

(4) Evaluate the sources, locations, and processes affecting mobilization of sediment in the Nehalem River Basin. This evaluation would examine the influence of multiple potential sources, including roads, landslides (Johnson and Maser, 1999), land use practices, bank erosion and sediment transport from the lower reaches of the Nehalem and North Fork Nehalem Rivers, and their relative contribution to the overall sediment budget for the Nehalem Bay. 


\section{References Cited}

Anderson, C.W., 2007, Influence of Cougar Reservoir drawdown on sediment and DDT transport and deposition in the McKenzie River Basin, Oregon, water years 2002-04: U. S. Geological Survey Scientific Investigations Report 2007-5164, 42 p., accessed August 30, 2021, at https://pubs .usgs.gov/sir/2007/5164/.

Bragg, H.M., Sobieszczyk, Steven., Uhrich, M.A., and Piatt, D.R., 2007, Suspended-sediment loads and yields in the North Santiam River Basin, Oregon, water years 1999-2004: U.S. Geological Survey Scientific Investigations Report 2007-5187, 26 p., accessed August 30, 2021, at https://pubs.usgs.gov/sir/2007/5187/.

Gray, J.R., and Gartner, J.W., 2009, Technological advances in suspended-sediment surrogate monitoring: Water Resources Research, v. 45, no. 4, W00D29.

Johnson, J., and Maser, J., 1999, Nehalem River watershed assessment: Portland, Oregon, Prepared by the Environmental Sciences and Resources Department, Portland State University for the Upper and Lower Nehalem River Watershed Councils, accessed August 30, 2021, at http://web.pdx.edu/ maserj/project/project1/1.htm.

Roegner, G.C., Diefenderfer, H.L., Borde, A.B., Thom, R.M., Dawley, E.M., Whiting, A.H., Zimmerman, S.A., and Johnson, G.E., 2008, Protocols for monitoring habitat restoration projects in the lower Columbia River and estuary: Pacific Northwest National Laboratory, PNNL-15793, accessed September 24, 2020, at https://www.pnnl.gov/ main/publications/external/technical_reports/PNNL15793.pdf.
Schenk, L.N., Anderson, C.W., Diaz, P., and Stewart, M.A., 2016, Evaluating external nutrient and suspended-sediment loads to Upper Klamath Lake, Oregon, using surrogate regressions with real-time turbidity and acoustic backscatter data: U.S. Geological Survey Scientific Investigations Report 2016-5167, 46 p., accessed August 30, 2021, at https://doi.org/10.3133/sir20165167.

Schenk, L.N., and Bragg, H.M., 2014, Assessment of suspended-sediment transport, bedload, and dissolved oxygen during a short-term drawdown of Fall Creek Lake, Oregon, winter 2012-13: U.S. Geological Survey Open-File Report 2014-1114, 80 p., accessed August 30, 2021, at https ://pubs.er.usgs.gov/publication/ofr20141114.

Shaff, C., Reiher, K., and Campbell, J., 2007, OWEB guide to photo point monitoring: Salem, Oregon Watershed Enhancement Board, 16 p., accessed on September 24, 2020, at https://digital.osl.state.or.us/islandora/object/ osl:16450.

Sobieszczyk, S., Bragg, H.M., and Uhrich, M.A., 2015, Waterquality conditions and suspended-sediment transport in the Wilson and Trask Rivers, northwestern Oregon, water years 2012-14: U.S. Geological Survey Scientific Investigations Report 2015-5109, 32 p., accessed August 30, 2021, at https://dx.doi.org/10.3133/sir20155109.

Wood, M.S., and Teasdale, G.N., 2013, Use of surrogate technologies to estimate suspended sediment in the Clearwater River, Idaho, and Snake River, Washington, 2008-10: U.S. Geological Survey Scientific Investigations Report 2013-5052, 30 p., accessed August 30, 2021, at https://doi.org/10.3133/sir20135052.

Wright, S.A., and Schoellhamer, D.H., 2005, Estimating sediment budgets at the interface between rivers and estuaries with application to the Sacramento-San Joaquin River Delta: Water Resources Research, v. 41, W09428, 17 p., accessed August 30, 2021, at https://doi.org/10.1029/ 2004WR003753. 
Publishing support provided by the U.S. Geological Survey Science Publishing Network, Tacoma Publishing Service Center

For more information concerning the research in this report, contact the Director, Oregon Water Science Center

U.S. Geological Survey

2130 SW 5th Avenue

Portland, Oregon 97201

https://www.usgs.gov/centers/or-water 


\section{$\frac{\mathbb{2}}{3}$}

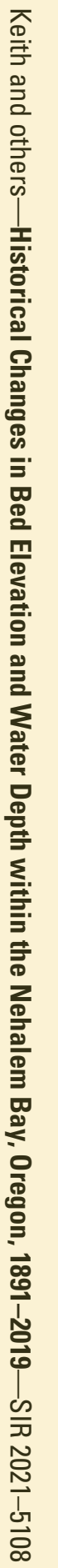

